المرأة والمجتمع الملني في مصر

$$
\begin{aligned}
& \text { إعداد } \\
& \text { عبير محمدل عباس محمد رفاعي } \\
& \text { مدرس بقسم الاجتماع } \\
& \text { كلية الآداب / جامعة دمياط بقاط الاجماع }
\end{aligned}
$$


- 


\section{المرأة والمجتمع المدني في مصر}

تمهيn

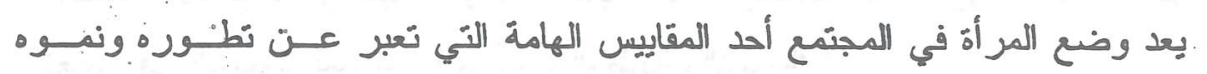

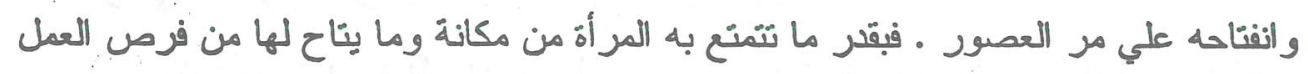

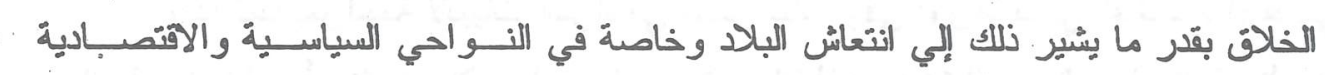

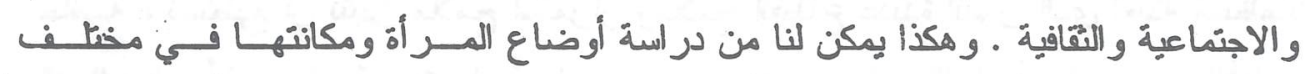

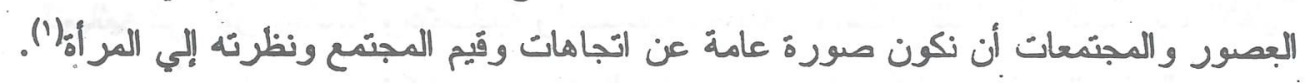

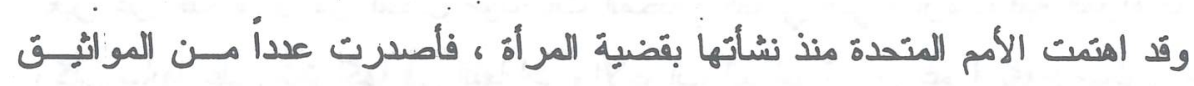
والاتفاقات الخاصة بها ، إضافة إلي عدد كبير من القرار ات و النوصيات الصادرة: عن الجمعية

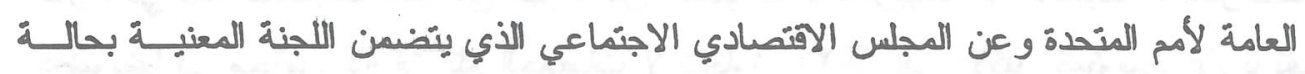

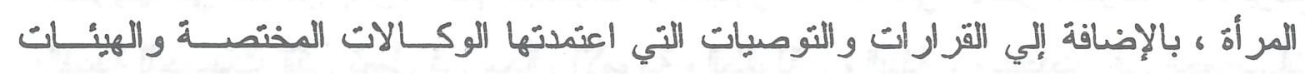

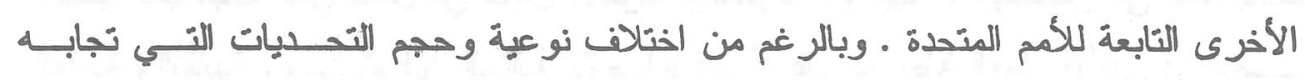

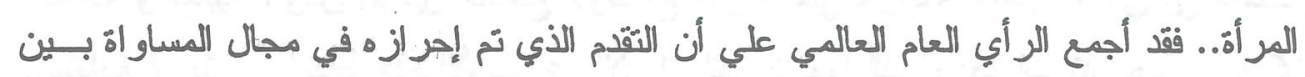

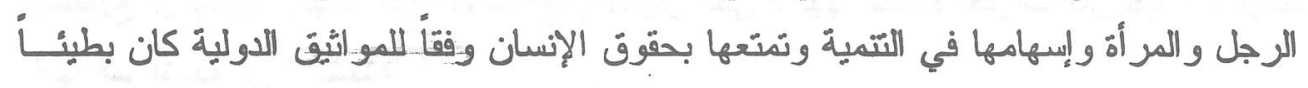

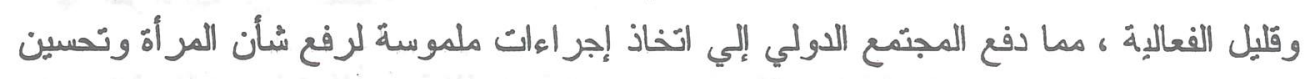

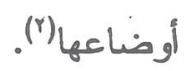

ولم تعد مشاركة المر أة في الحباة العامة حالة من الترف الفكري و الثقافي ، بقدر مـــا

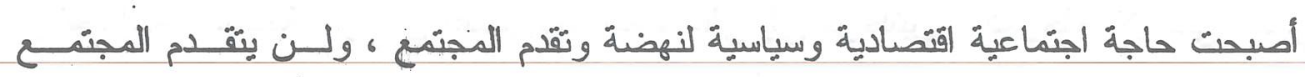

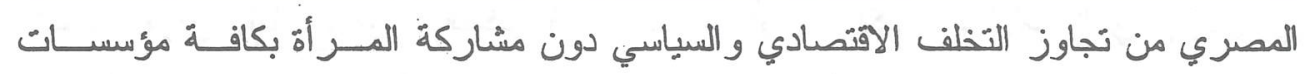

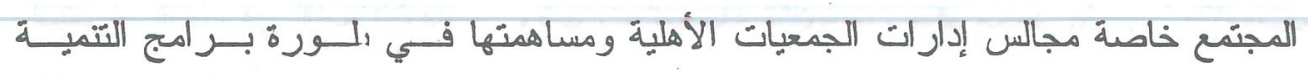

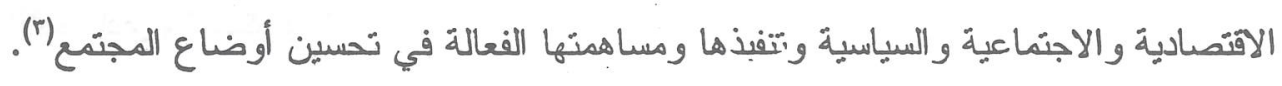

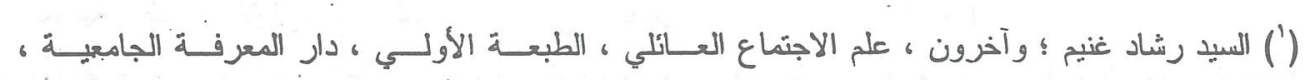

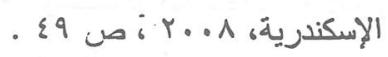

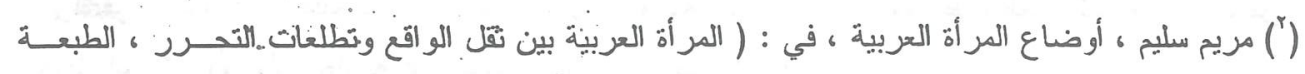

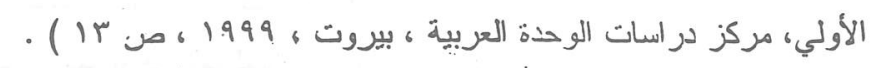

$\left({ }^{3}\right)$ http://www. 1 chr-eg.org/100/100-72.htm: - $\neg \& r_{-}$ 
أولاً : تاريخ مشاركة المرأة في المجتمع المدني في مصر

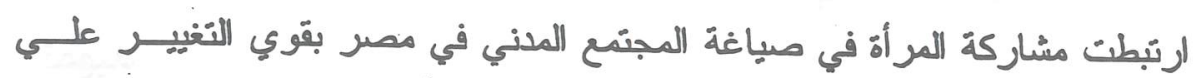

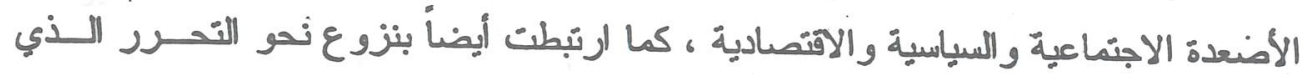

انعكس في الصعود المتز امن للحركات الوطنية و النسويةًا' (1).

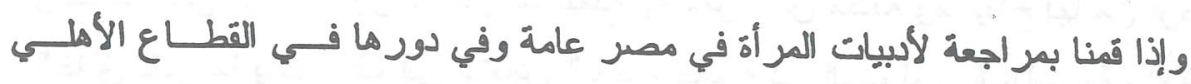

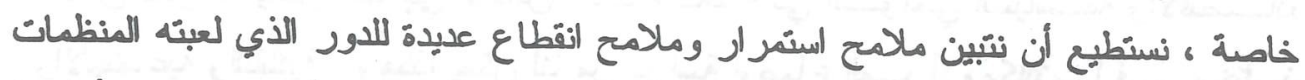

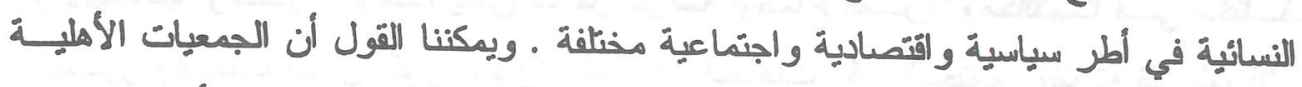

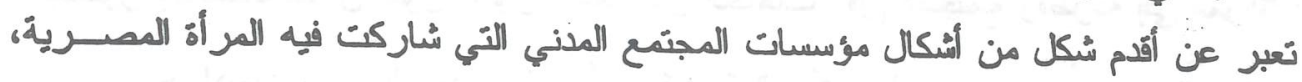

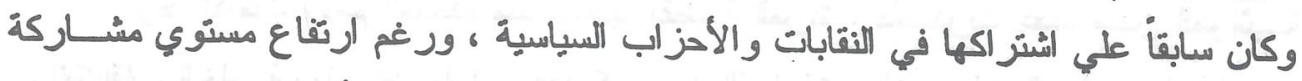

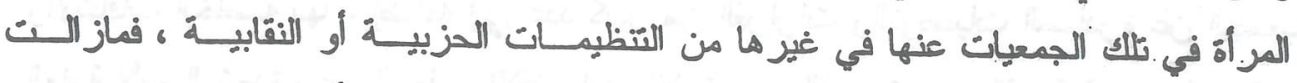

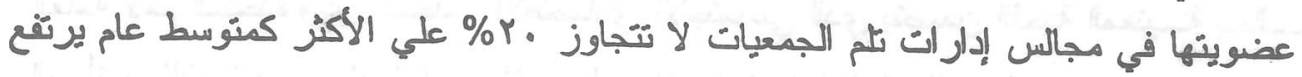

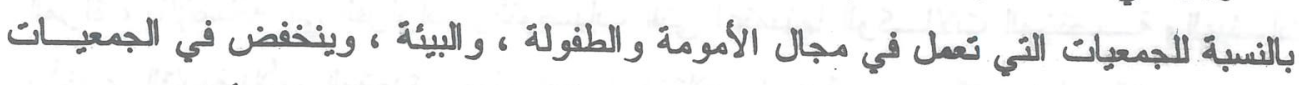

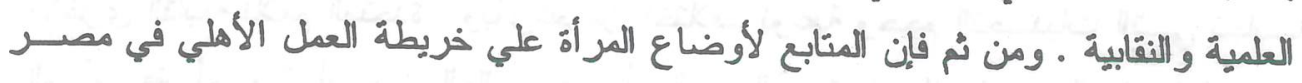

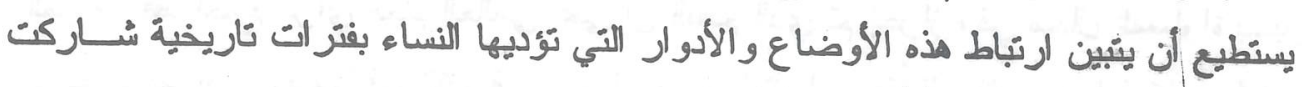

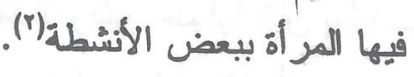

$$
\text { 1- ميلاد الجمعيات الأهلية النسائية في مصر (ق 19 19rr - 19r ) }
$$

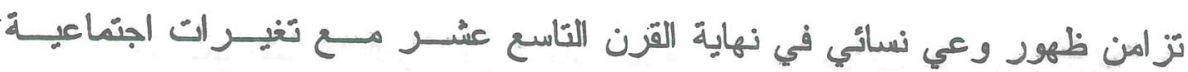

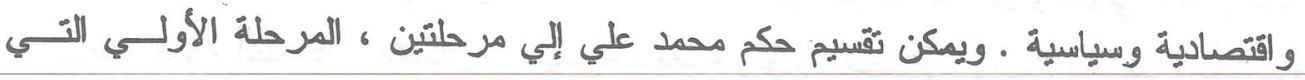

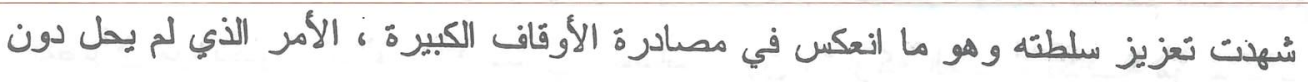

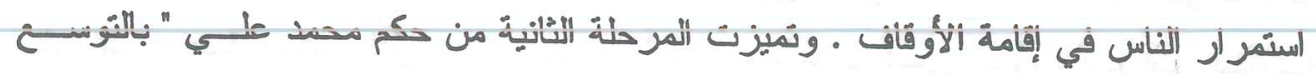

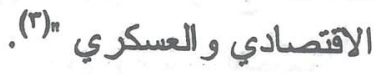

(') هالة شكر الهة ؛ وآخرون ، مصر : المر أة في المنظمات الأهلية ، في : ( المرأة في المنظمات الأهليــة

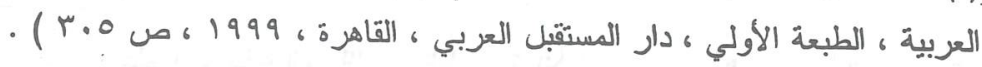

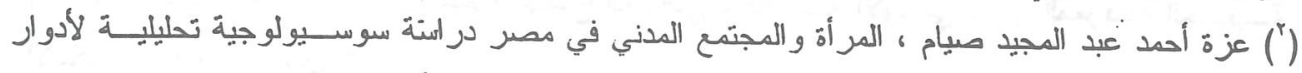

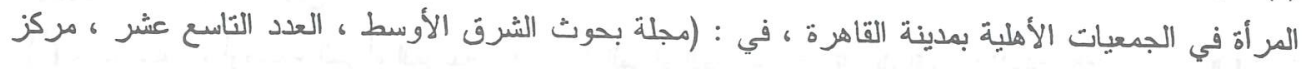

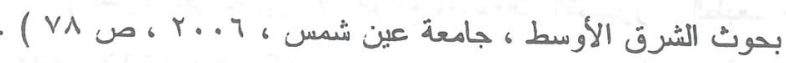

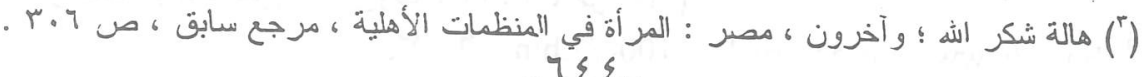


وفي إطار محاولة معمد علي بناء الدولة الحديثةة ، بدأت حركة تحديث النَعلـيم عـام

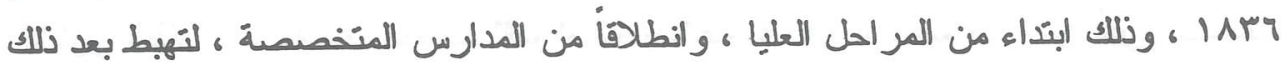

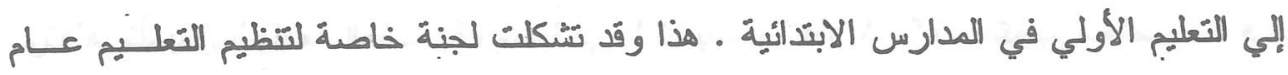

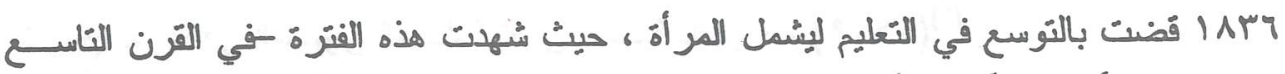

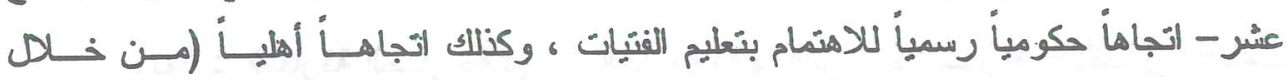

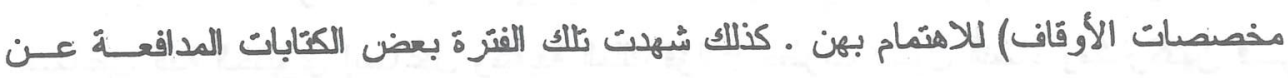
تنعليم البنات ، و هو ما كان له أبغ الأثر في تهيئة المناخ لعل نسائي تطوعي منظم ينبنى هذه

(القضضية) (1)

ومع نهاية القرن التَاسع عُر وبداية القرن العشرين جاءت كتابات قاسم أمين ليتجدد دعوة كل من رفاعة رافع الطهطاوي و الشيخ محمد عبده ووسع نطاقها ، حنى أنه ليعد بحسنق

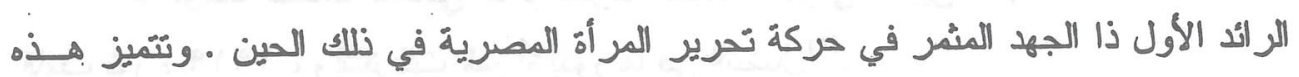

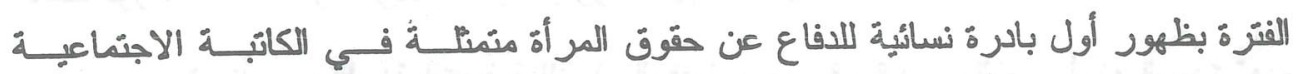

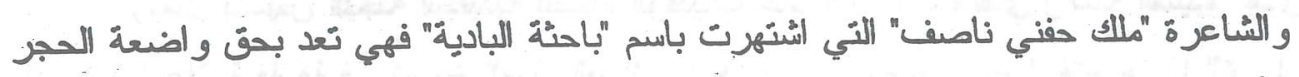

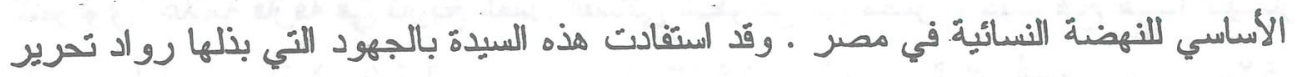

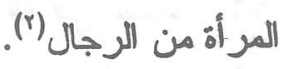

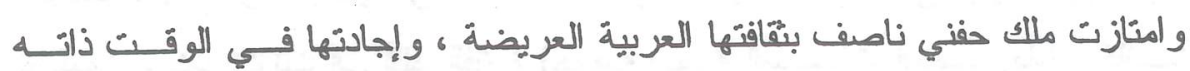

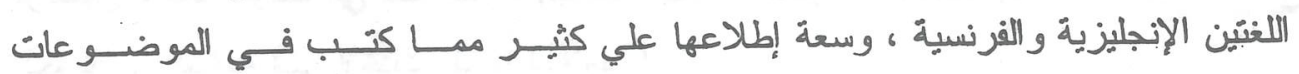

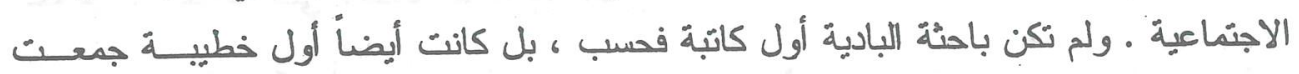

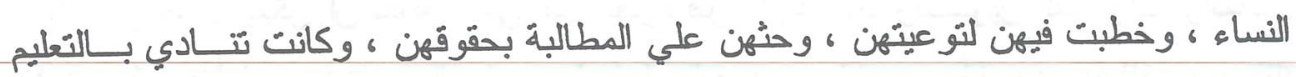

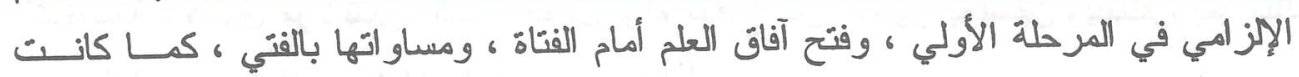

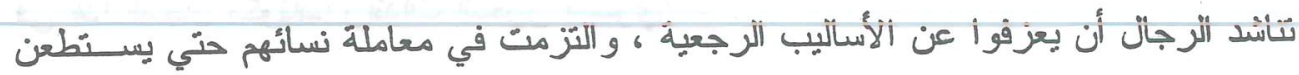
تتشئة الأجيال الجديدة علي الحربة(").

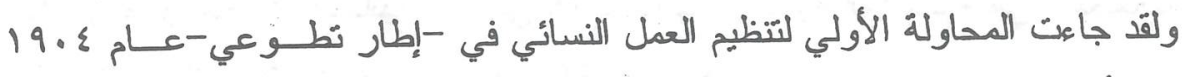
حين دعت الأميرة "عين الحياة" إلي تأليف جماعة من السيدات المصريات لإقامة ملعباً رياضياً

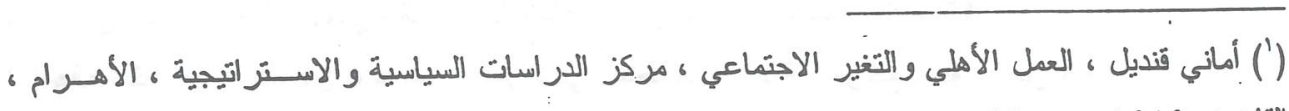
القاهزة، 1919 ، ص ع ك .

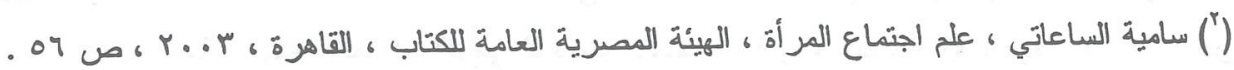

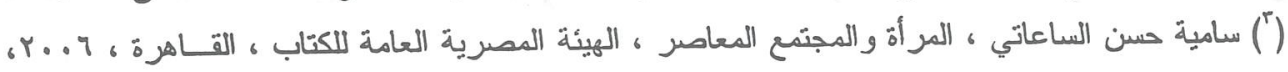
$-7 \leqslant 0$. 
خاصاً للسيدات ـ وفي عام V • 19 نطورت فكرة تجميع النساء وذللك بدعوة النساء إلي العناية

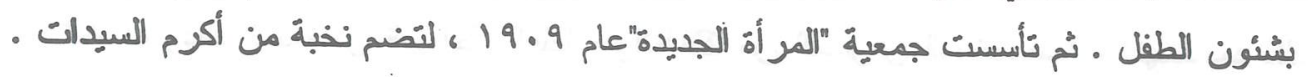

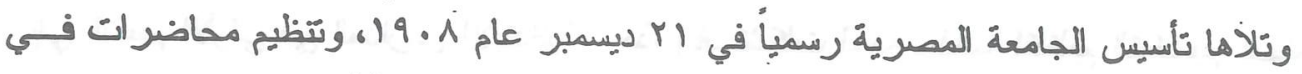
تاريخ المر أة في العصور المختلفة تكون خاصة بالسيدات (9 ـ 19 (1).

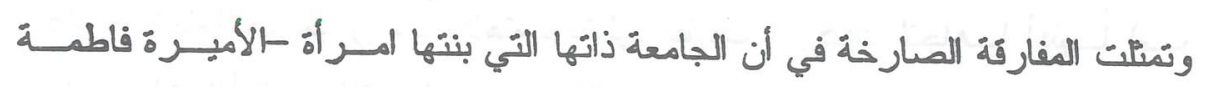

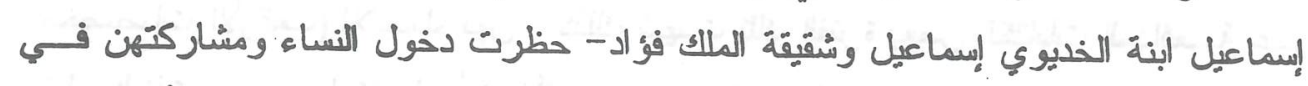
حياتها الثقافية ، بل ومنعت النساء بالقوة من عقد اللقاءات وتنظيم المعاضرات بهات أبام الجمع.

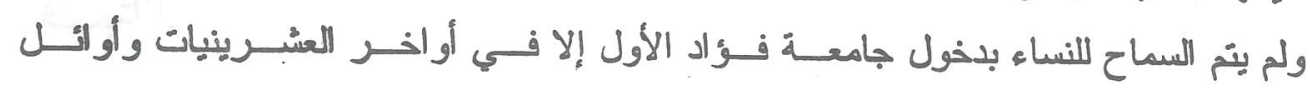

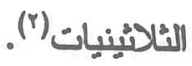

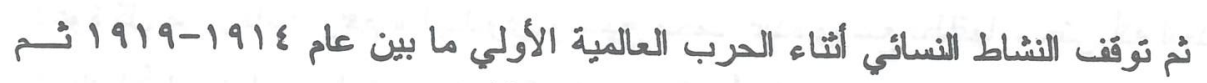

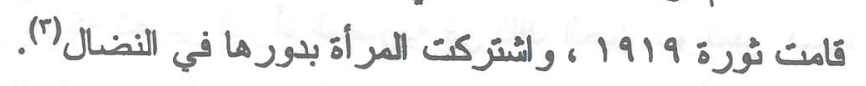

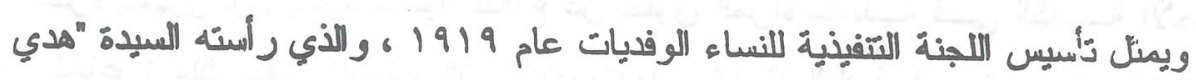

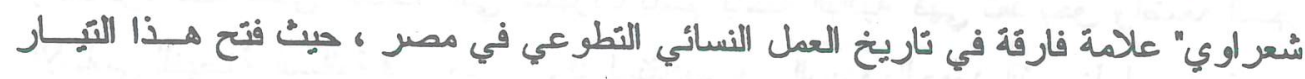

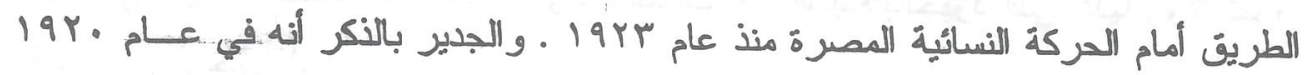

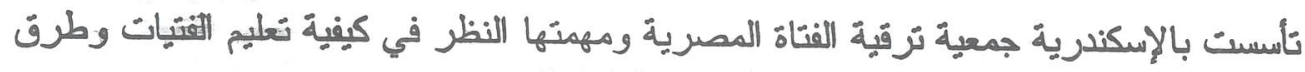

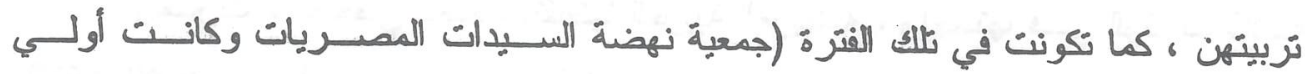
الجمعيات النسائية التي اتخذت طابعاً إسلامباً ) .

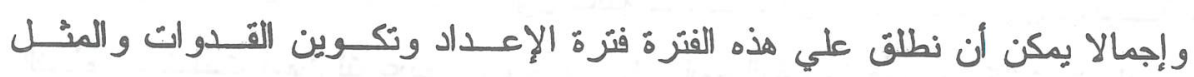

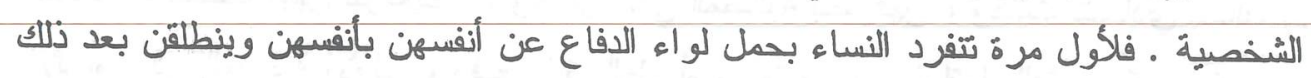

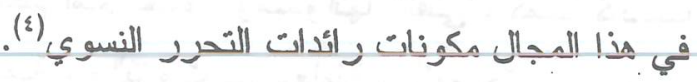

وبهذا بمكننا القول أن المرحلة الزمنية منذ القزن التاسع عشر وحنى عام بو 19 تمنل ميلاد وتطور الحركة النسائية ، والتي كانت أداتها الرئيسية المؤسسية هي المنظمات النسائية الطوعية ، و التي عكست بذور هذه الحركة وتطور هاء").

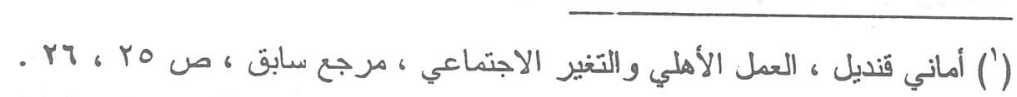

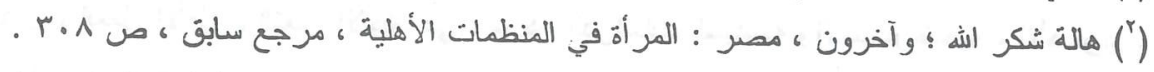

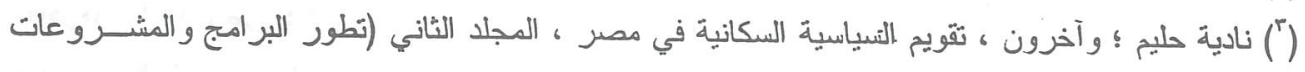

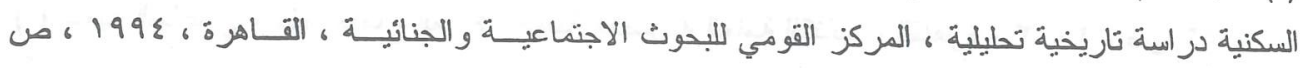




$$
\text { r - العهد الليبرالي (194T-190r) }
$$

شهرت فتزرة العهد الليبر الي نموأ وازدهار أ في العمل الأهلي عامة ، كما شهرت تتوعاً

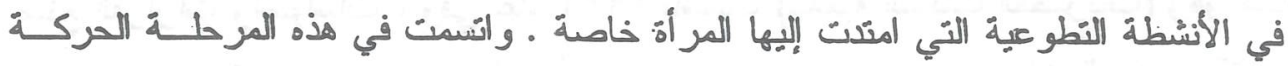

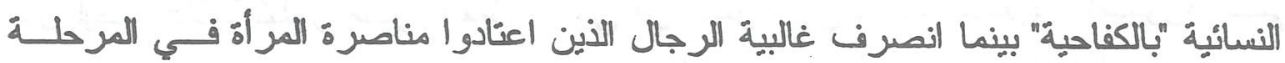

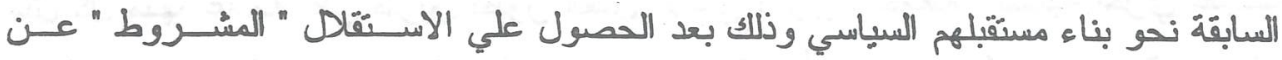

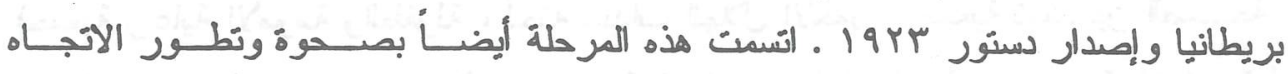
الإسلامي المحافظ بين بعض القيادات النسائية و هو ما انعكس علي الطبيعة الغاصة لأنشــطنة

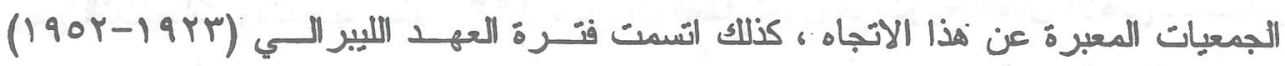

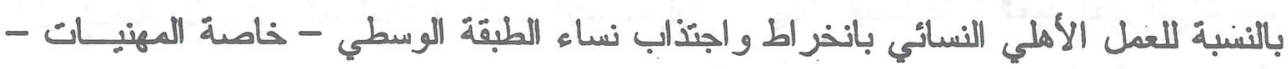

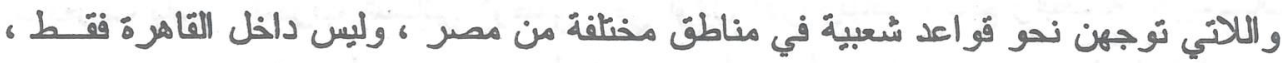

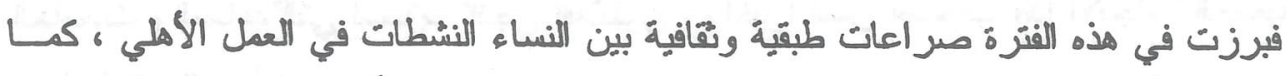

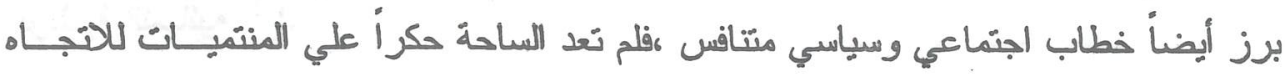

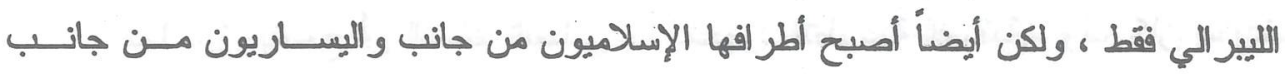

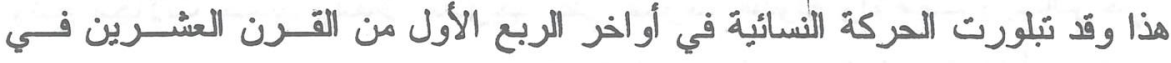

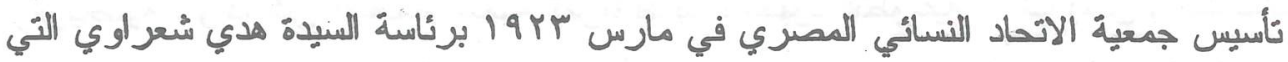

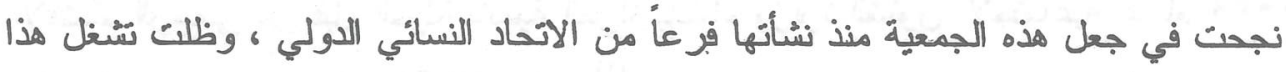

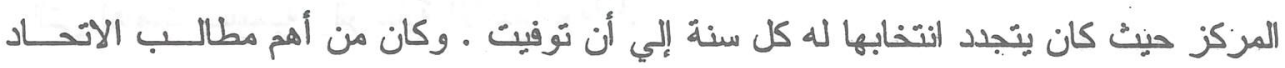

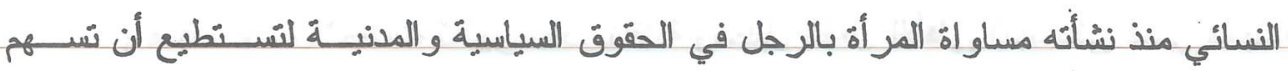

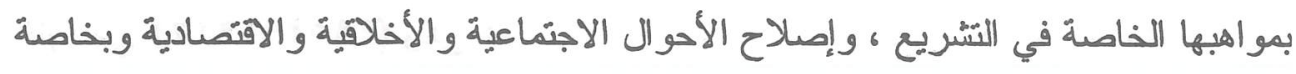

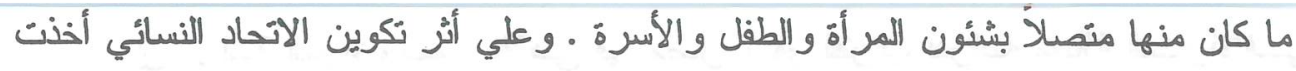

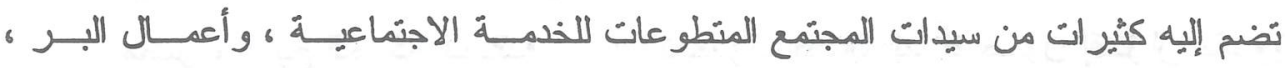

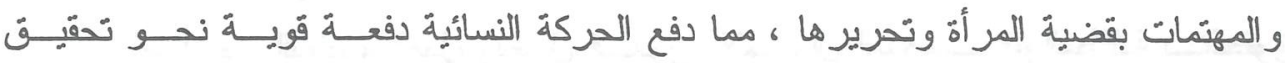

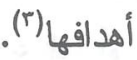

(') عزة أحمد عبد المجيد صبام ، المر أة والمجتمع المدني في مصر دراسة سوسـيولوجية تحليليــة لأدوَار

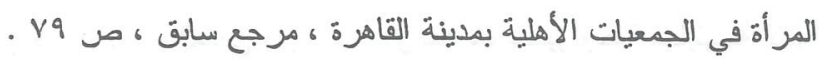

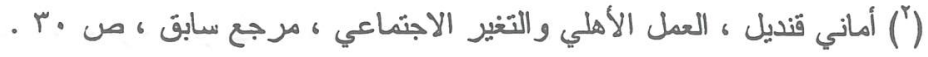

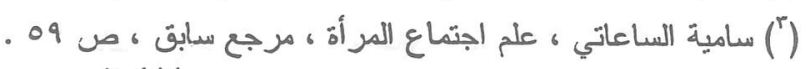
$-7 \varepsilon V$. 


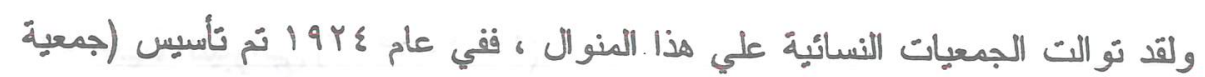

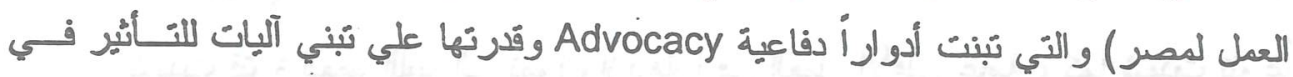

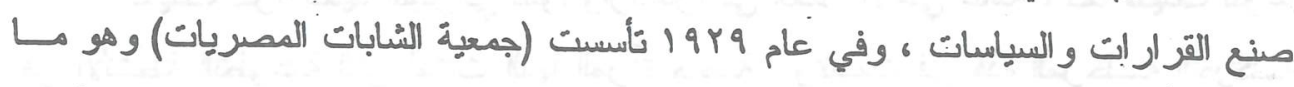

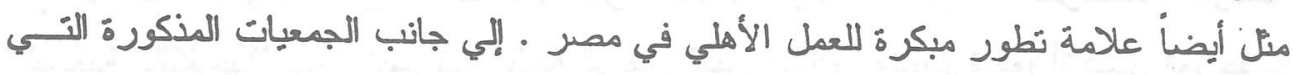

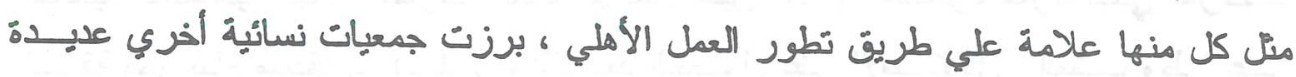

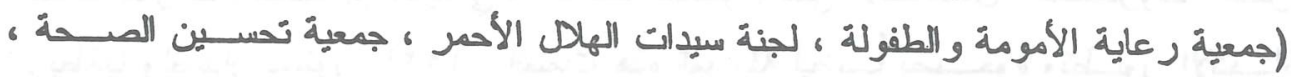

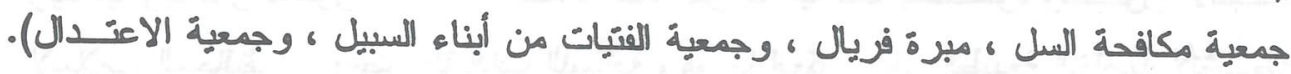

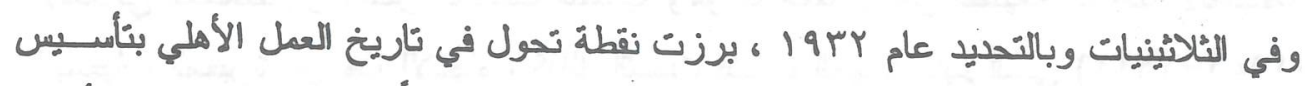

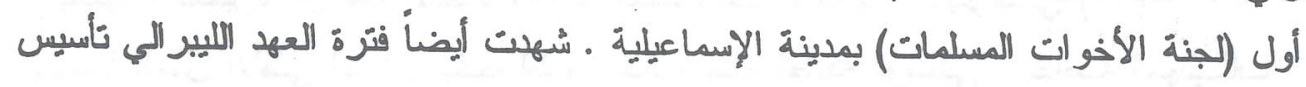

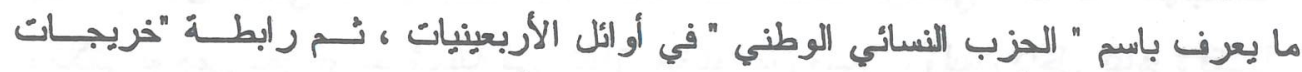

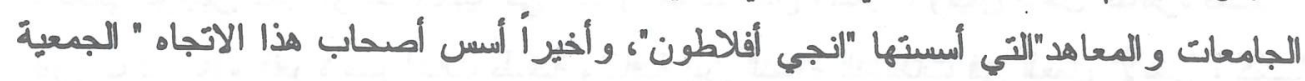

الوطنبة النسائية "( (1).

مما سبق يتضح أن النشاط النسائي بدأ بالجهود النُطوعية النسائيةً ، وأنه كان ستّهف

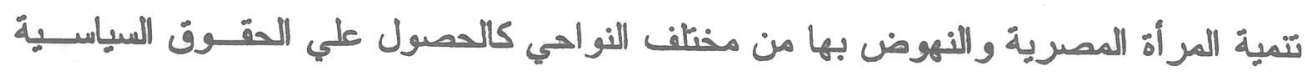

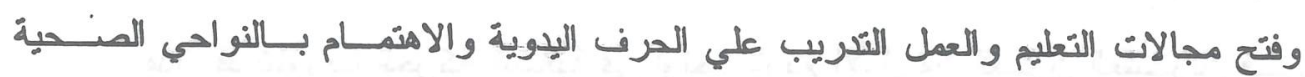

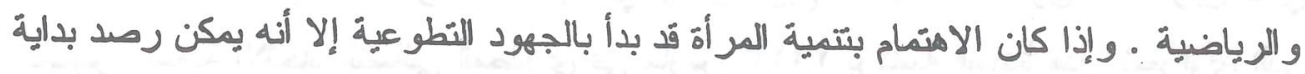

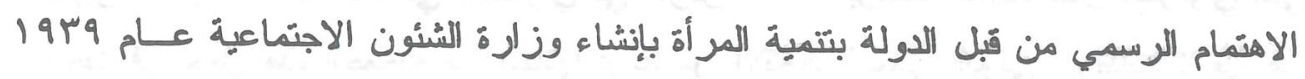

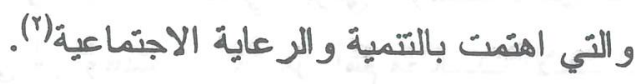

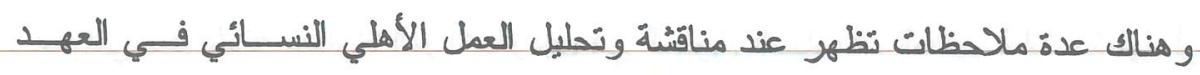

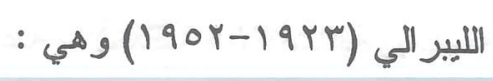

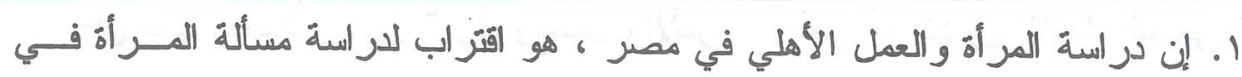

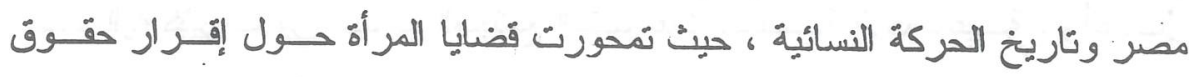

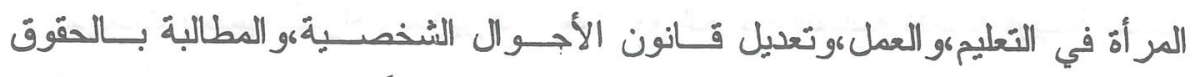

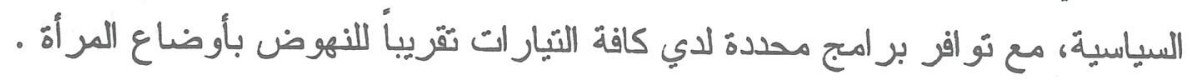

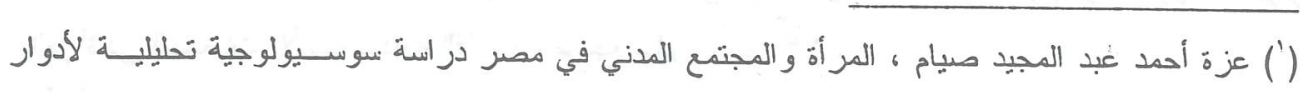

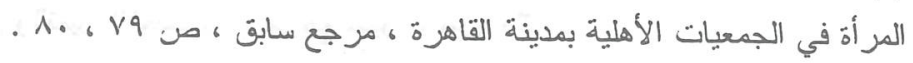

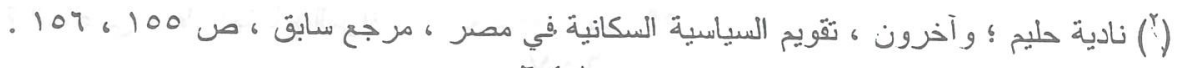




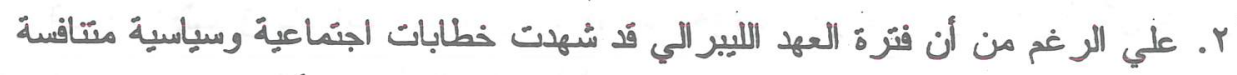
من جانب النساء اللتي انخرطن في العمل الأهلي ، ولكن أيضاً كانت هناك تحالفات

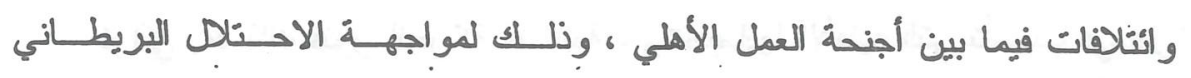
والمطالبة بالتحرر القومي •

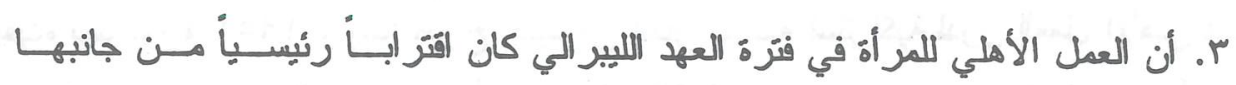

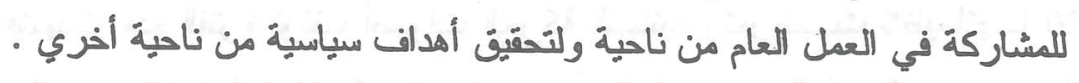
ع. إن العمل الأهلي النسائي في مصر خاصدة في الأربعينبات ، قد فتح أبواباً أمام نســاء

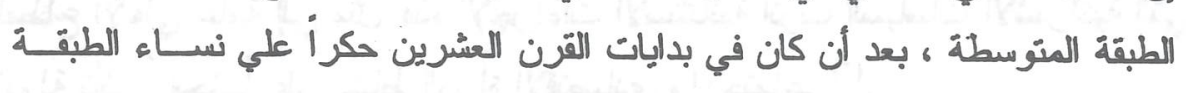

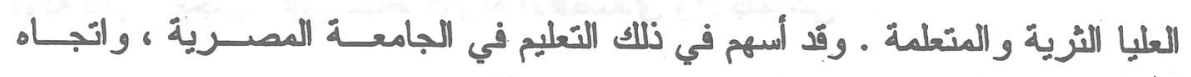
بعض نساء الطبقة المتوسطة إلي العمل و التميز المهني .

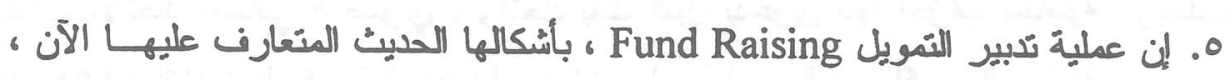

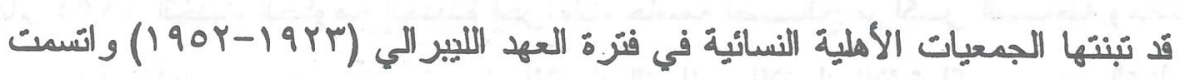

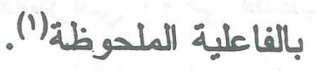

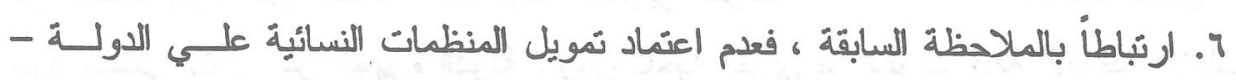

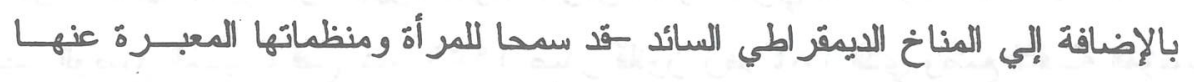
بالنشاط كتنظيمات دفاعية Advocacy Organization ـ فالمطالبة بالحقوق و الدفاع عن مطالب المر أة خاصة ، قد اتسم بفاعلية ملحوظة. ولا شُك أن إسهام المر أة في العمل الأهلي خلال هذه الفترة الثرية بالخبرات و النماذج

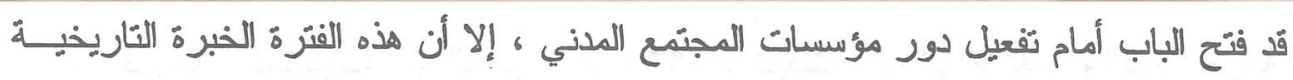

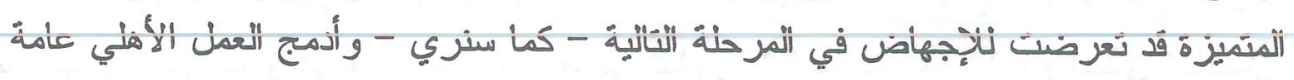

$$
\text { و النسائي خاصة في الدولة(r). }
$$

بدأت هذه الفترة بعد انتهاء الحرب العالمية الثانية ، وتميزت هذه الحقبة بالتوسع فـي

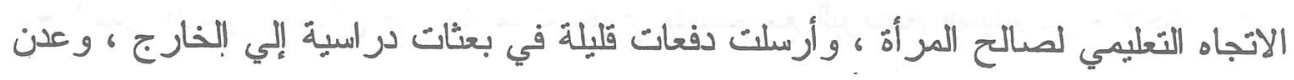
يحملن أرقي الشهادات في تخصصات شتي في نفس الوقت الذي أنيح فيه للافحات القلبلة الولي

$$
\begin{aligned}
& \text { (') أماني قنديل ، العمل الأهلي والتغير الاجتماعي ، مرجع سابق ، ص دب - . ع . }
\end{aligned}
$$

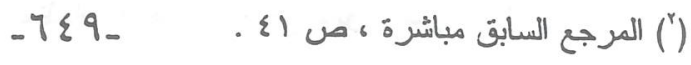




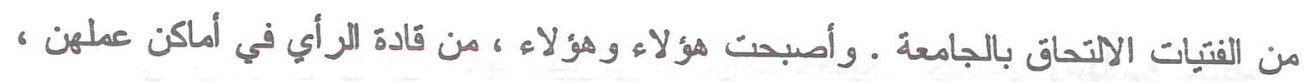
كما أصبحن طلائع طيبة للمرأة المنطورة." (1) .

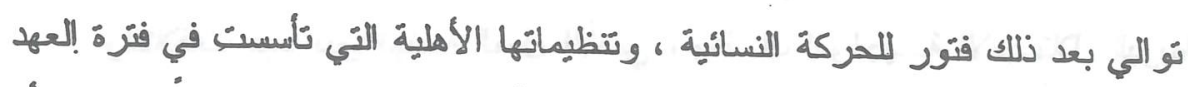

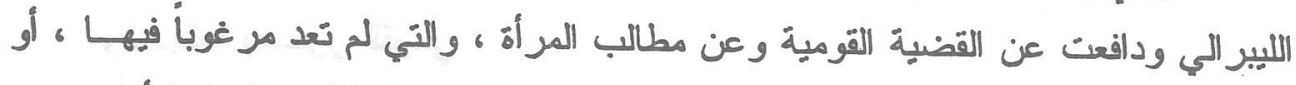

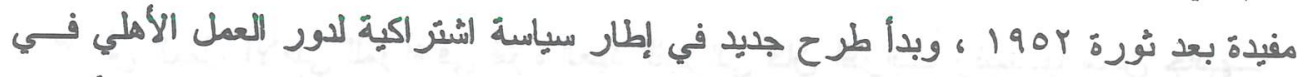

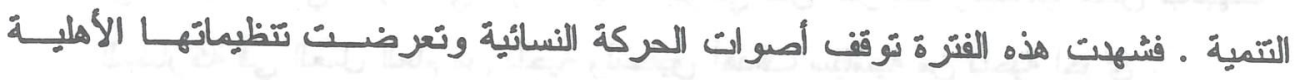

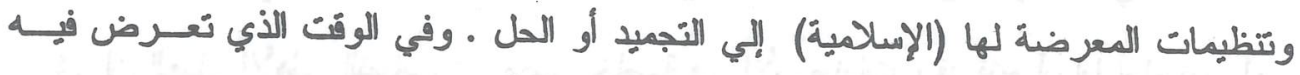

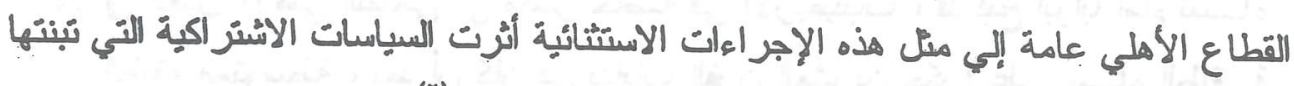

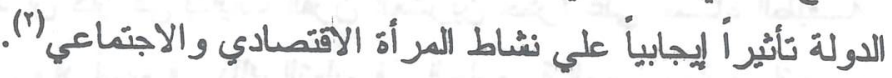

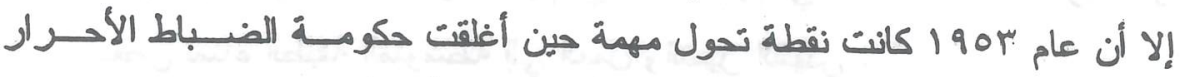

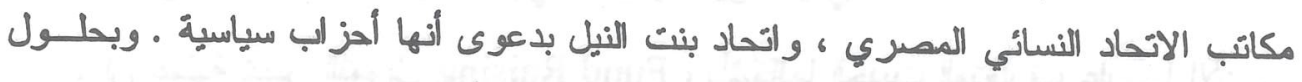

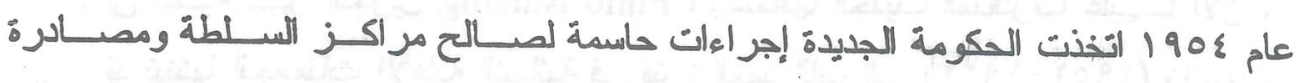

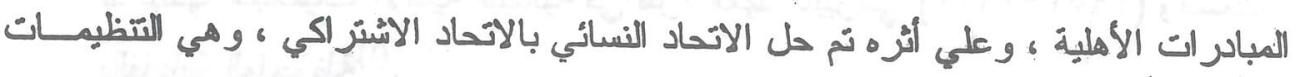

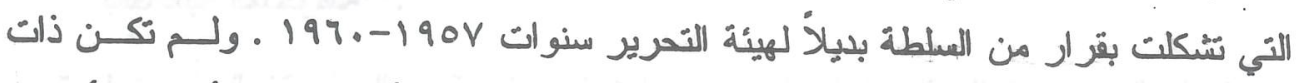

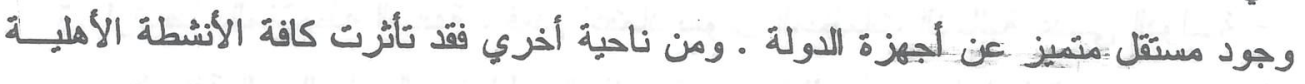

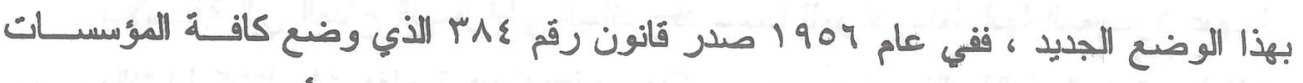

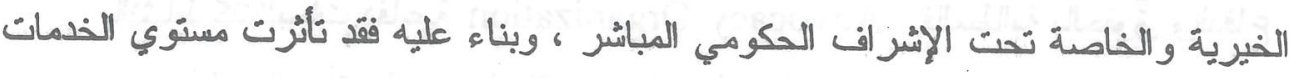

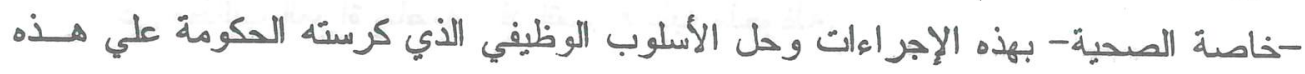
الأعمال محل روح التطوع و التفاني (r).

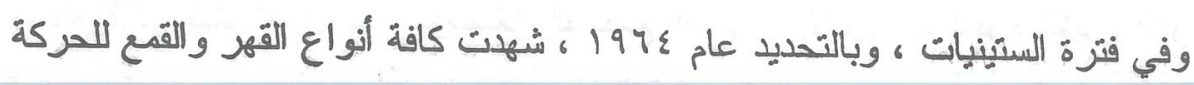

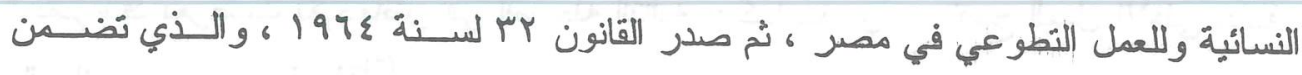

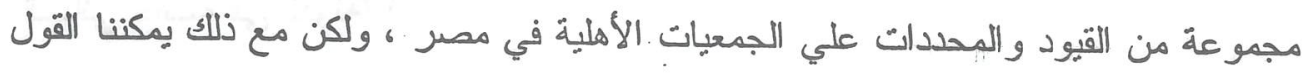

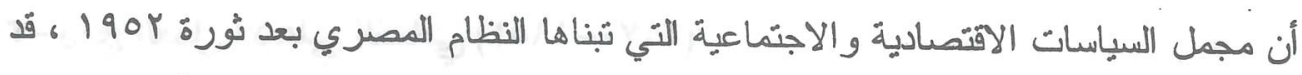

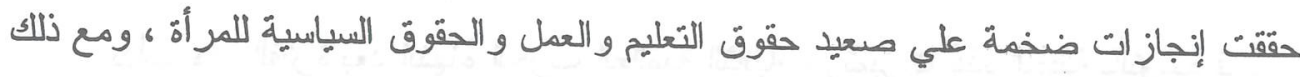

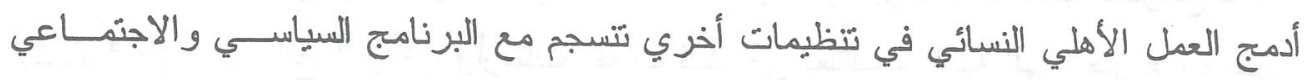

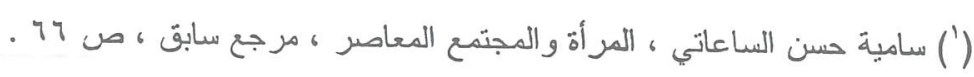

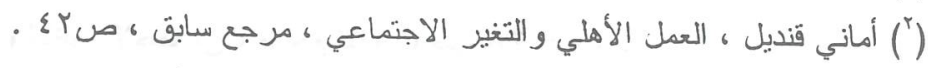

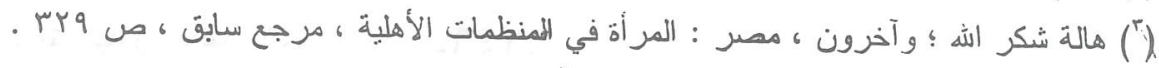

$$
\begin{aligned}
& \text {-70. - }
\end{aligned}
$$


للاولة، إذا اختطت عضوية الاتحاد الاشتر اكي العربي في (السنينيات) مع عضوية الجمعيات

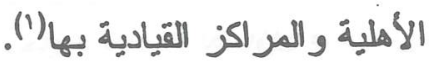

وتنلفص أهداف التنظئيات النسائية في هذه المرحلة فيما يلي : ا ـ النعبئةُ العامة للنساء في مختلف المحافظات . r . تنظيم جهودهن للقيام بكافة الواجبات التي يفرضها المجنمع المصري عليهن r. نو عيةً المر أة بحقوقها السياسيةً و القوميةً ، وتبصير ها بوسائل ممارسة هذه الحقون . ع. تُوعيةٌ النساء. لقبد أسمائهن في جداول الانتخاب . ○. الانتظطام في عضوية المتظيم السياسي .

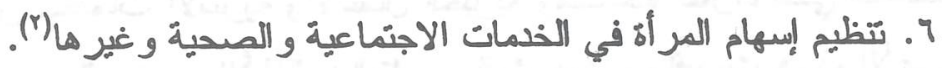
ع- الجمعيات الأهليـة النسـائية وسياسـات التحريـر الاقتصادي والتحـول الـيمقراطي $(1997-197 \cdot)$

لم تشّهد السبعينيات تحركات نسائية نذكر ولا محاو لات حقيقية لإعــادة مجموعـات

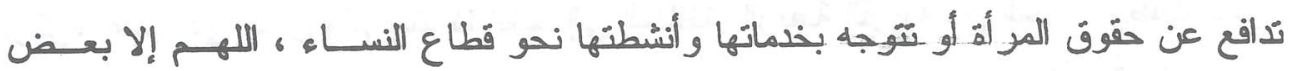

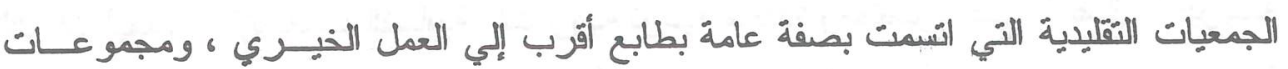

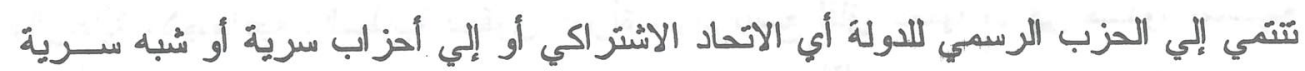

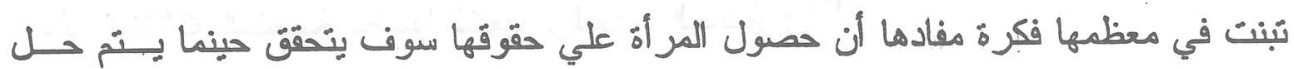

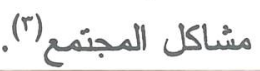

وعلي الجانب الآخر فإن الدور الدفاعي Advocacy الذي كانت بعــ الجمعيـات

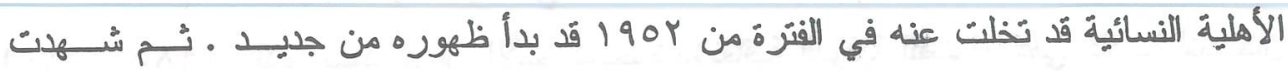

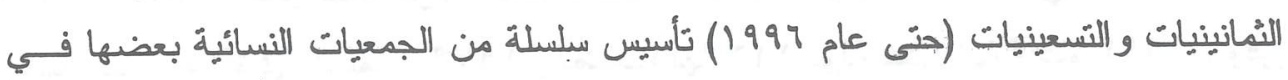

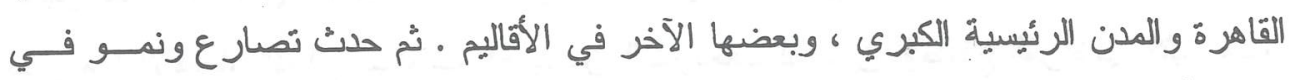

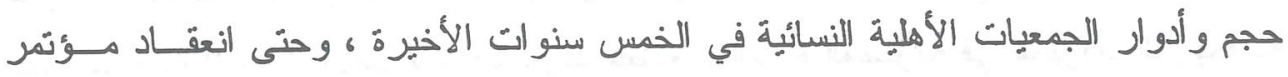
(') عزة أحمد عبد المجيد صيام ، المرأة والمجتمع المدني في مصر دراسة سوسـيولوجيةً تحليليــة لأدوار

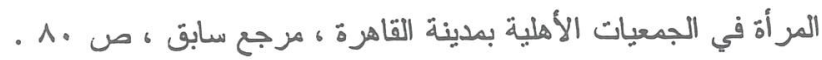

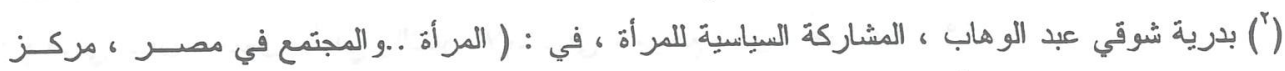

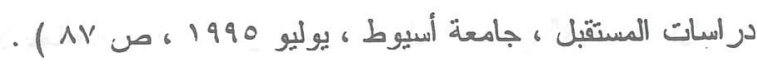

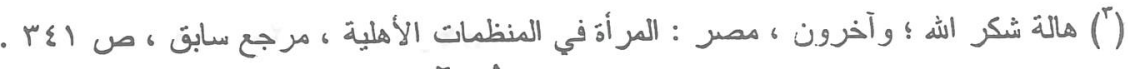




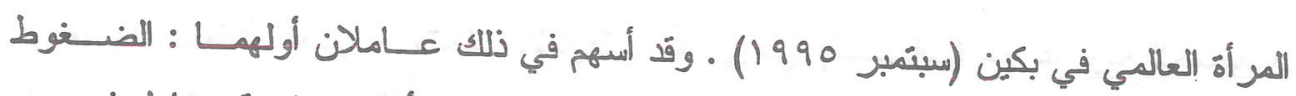

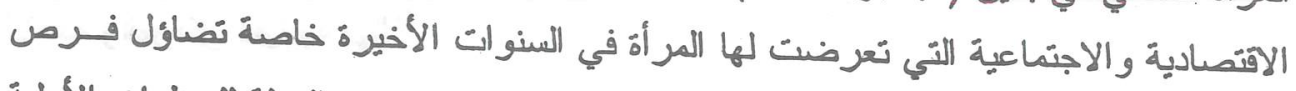

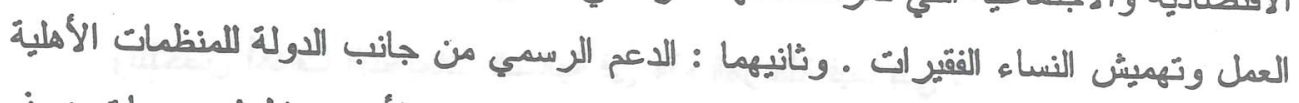

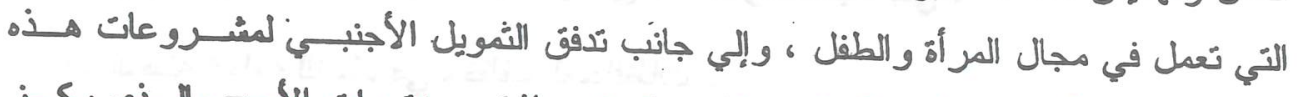

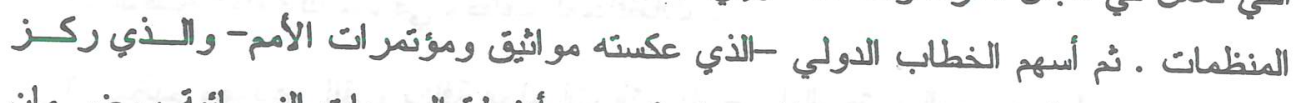

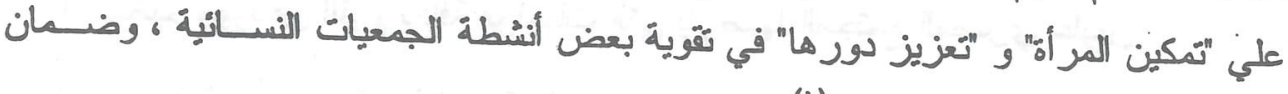
تدفق أموال المؤسسات الدولية لهابان.

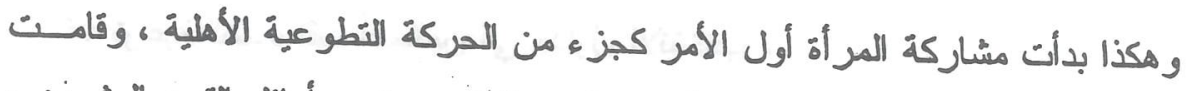

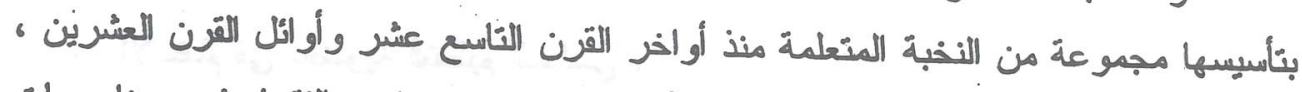

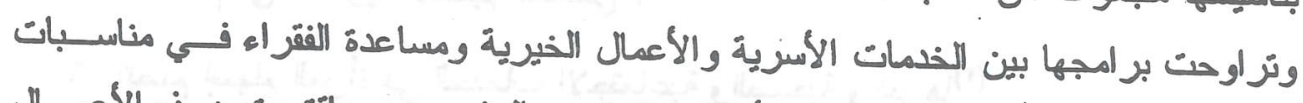

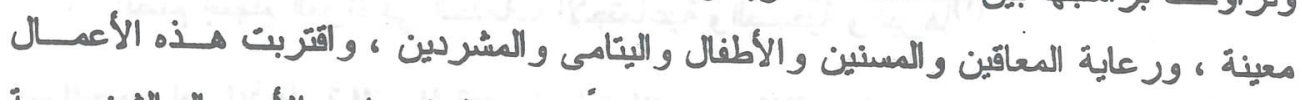

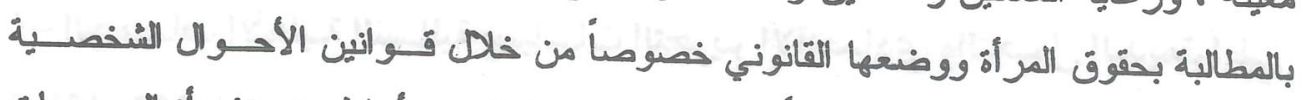

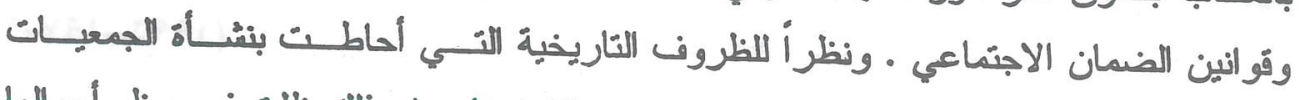

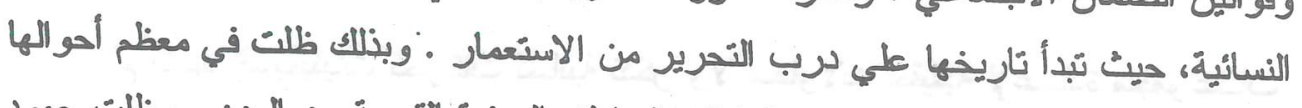

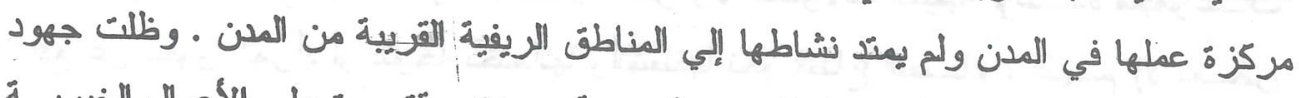

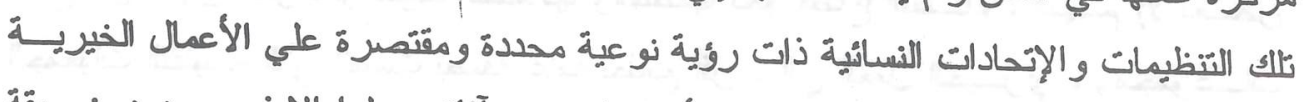

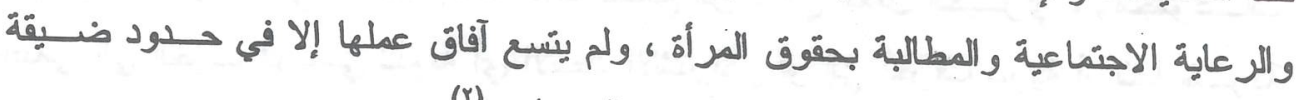

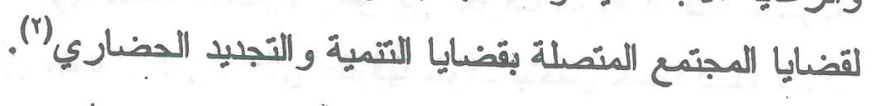
ثانياً : مشار كة المرأة المصرية في تنظيمات المجتمع الملاني

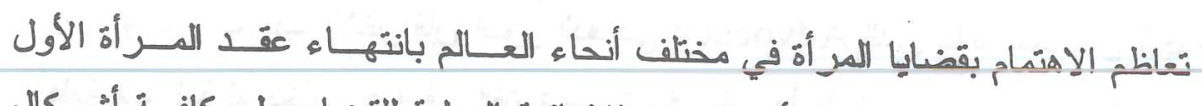

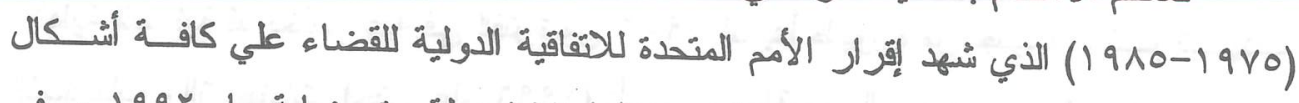

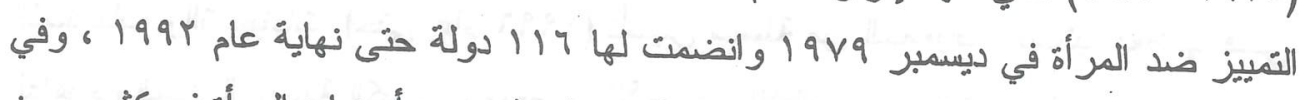

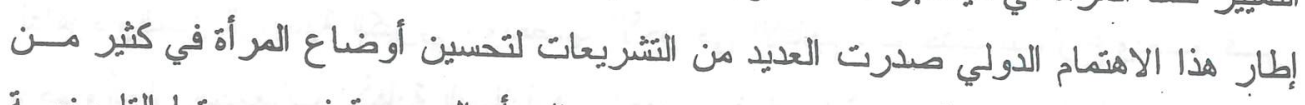

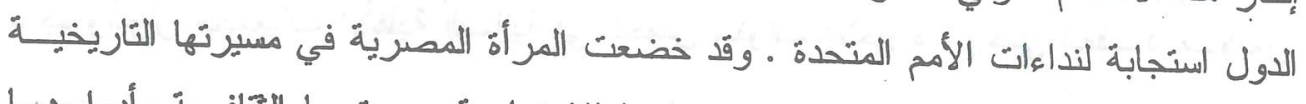

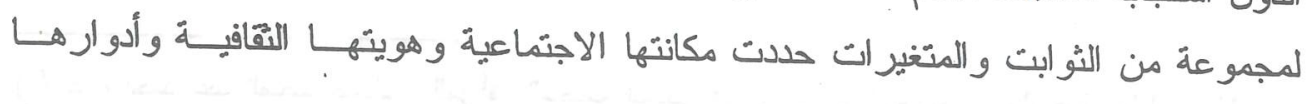

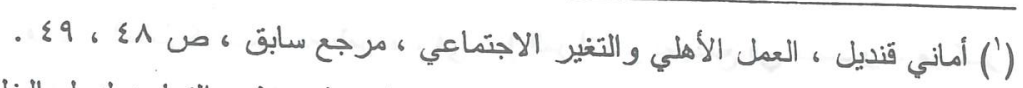

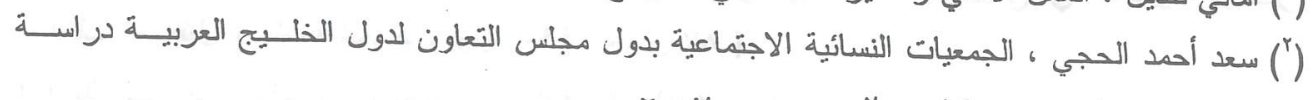

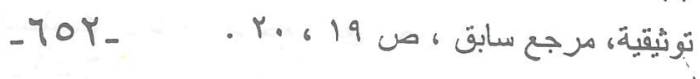




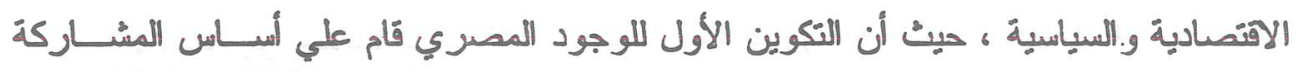

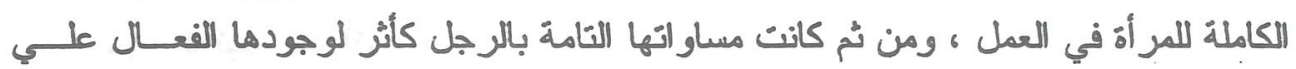

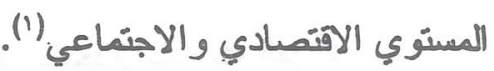

$$
\text { - أمشاركة المرأة في العمل الاجتماعي }
$$

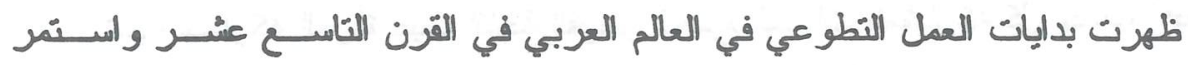
بوتائر مختلفة حسب الظروف الاجتماعية والاقتصادية والسياسية لكل دولة من الدول العربية

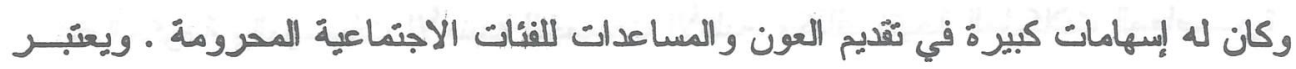

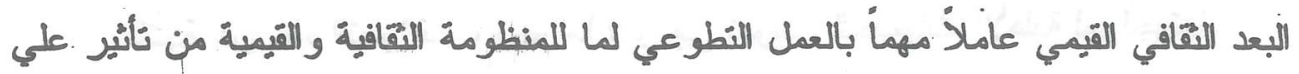
الدوافع والأسباب التي يحملها الأفر اد (r).

ولا شك أن المرأة لها دور تنموي في العمل الاجنماعي لا يسنطيع أحد إنكاره ، حبث

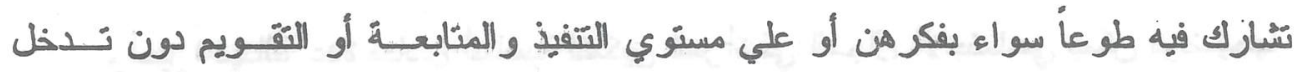

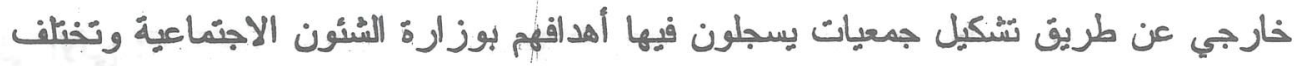

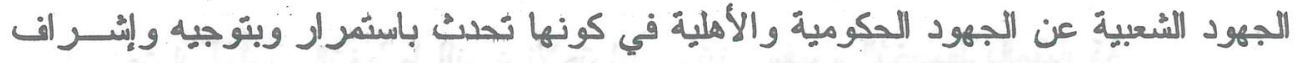

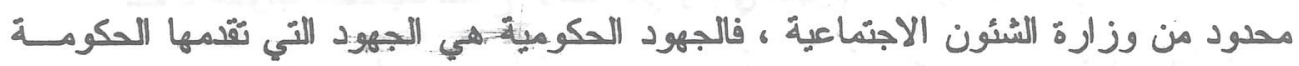

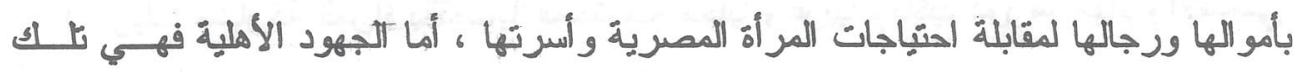
العمليات التي يقوم بها المواطنون طوعاً (r).

وتتأثر نسبة مشاركة المر أة في الجمعيات الأهلية بالثيو لات المجتمعية هيث نباينــت نسب المشاركة بين الارتفاع والانخفاض في الفتر ات التاريخيةً المختلفة. فقد ارتفعت مشاركة

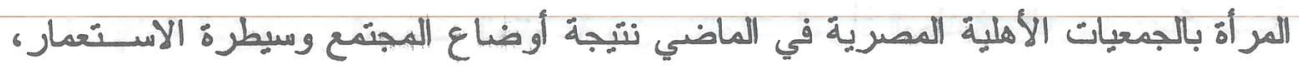

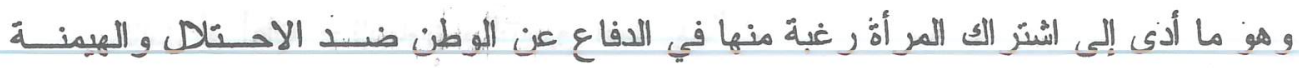
الغارجية. ثُ شُهدت المشُاركة انففاضا نتيجة أوضاع المجتمع المقيدة لعمل الجمعيات الأهلية

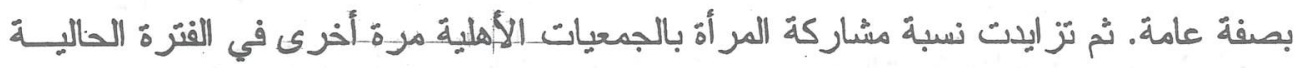

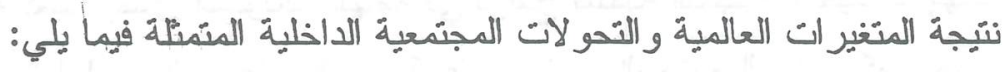
ا ـ الاهنمام العالمي بقضايا المر أة "مؤتمر المر أة والسكان نموذجا".

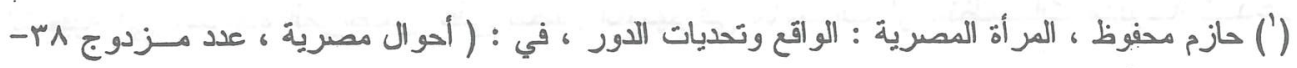

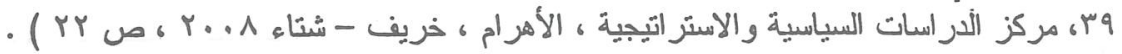

$\left(^{2}\right)$ http://pcrp.org/esdarat6.htm1

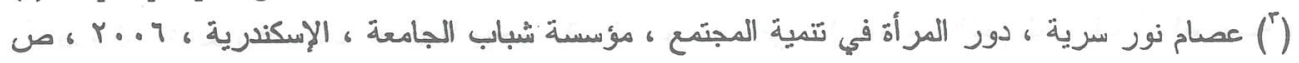
-ror. 
ץ. بالإضافة إلى مساندة الدولة للمرأة، متمثلا ذلك في إنشاء المجلس القومي للمر أة ودعم

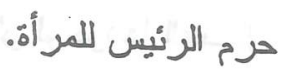

r. الاهتمام الإعلامي بالجمعيات الأهلية وبقضايا المرأة وتشّبيع مشاركة المرأة.

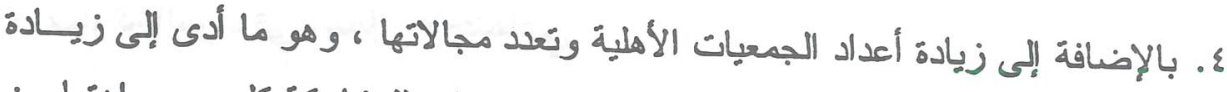

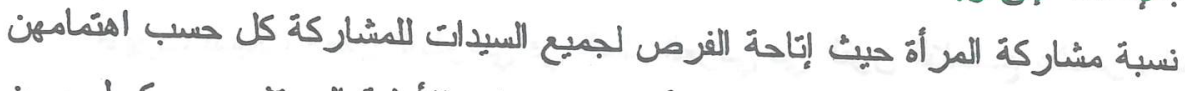

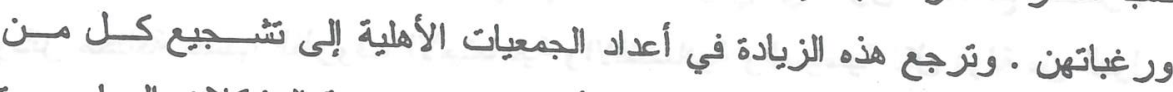

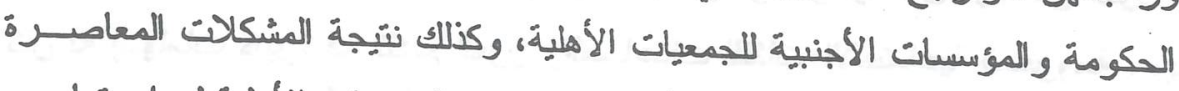

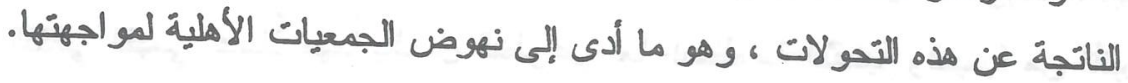

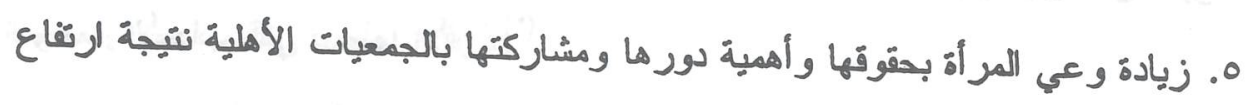
نسبة التعليم" (1). وأخيراً فهناك عدة مبادئ أساسية لتمكين المر أة في المجال الاجتماعي يمكن توضيحها I ا ـ اعتماد أسلوب التخطبط للنوع الاجتماعي وتبني مفهوم التخطيط بالمشاركة . في الآتي :

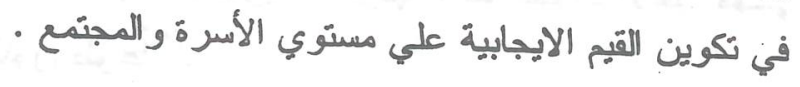

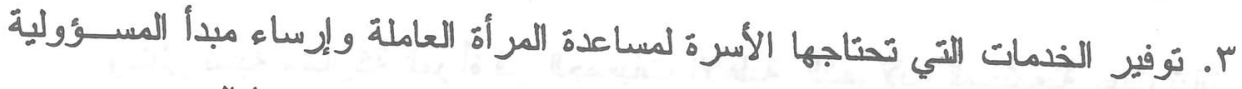

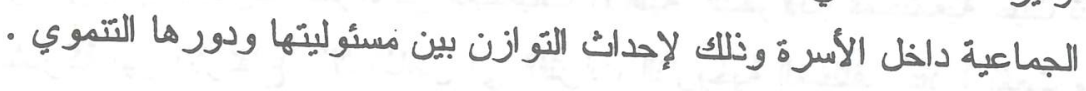

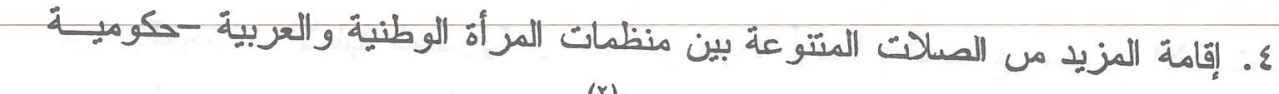

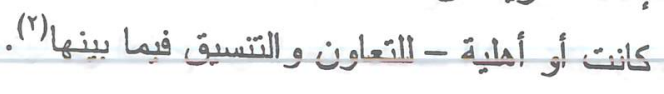

$$
\text { r- مفهوم المشاركة }
$$

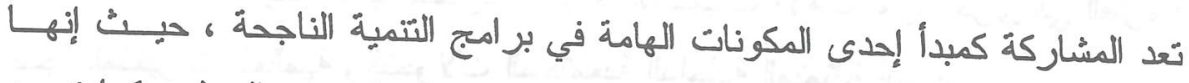

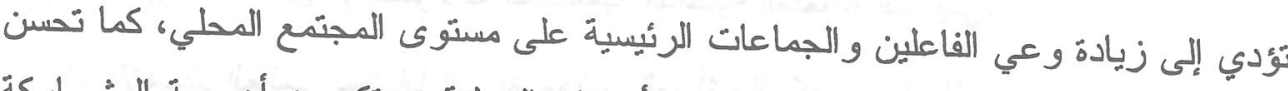

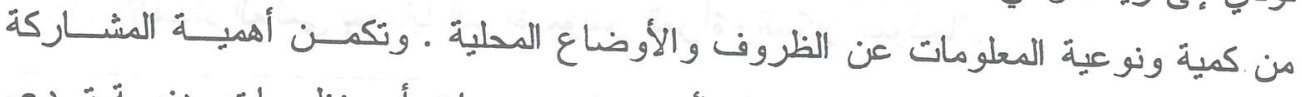

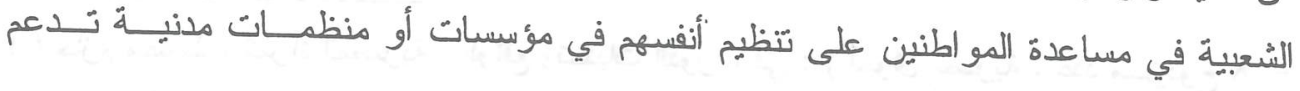

(') http://www.amanjordan.org/a-news/wmprint.php?ArtID=5055

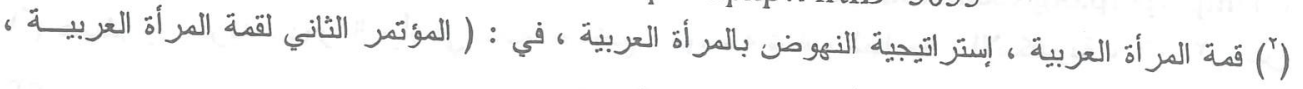

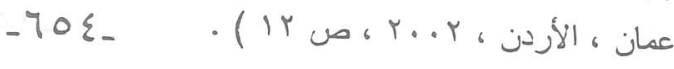




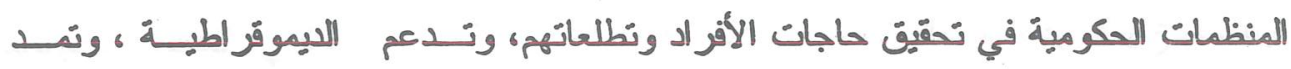

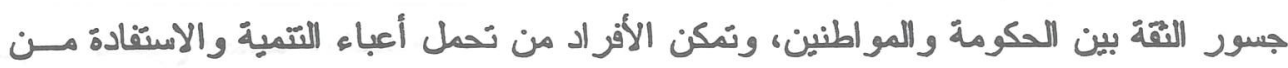

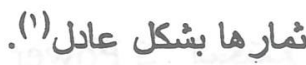

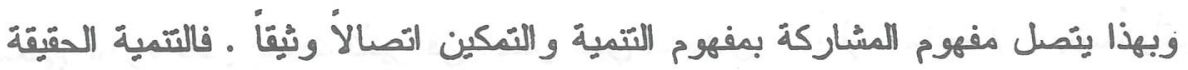

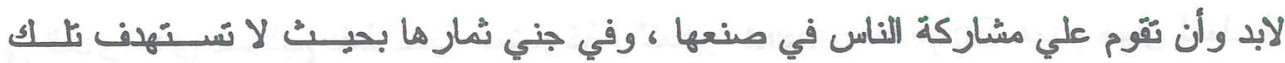

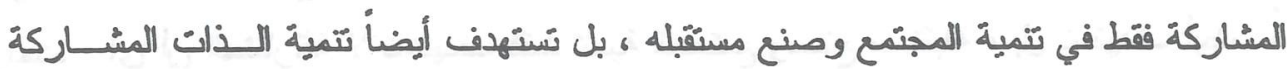

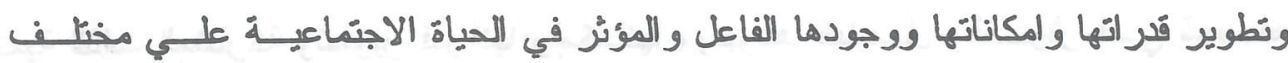
الأصعدة:(7).

ولعل التببيه إلي أهمبية المشاركة برجع إلي المضار ات القديمة مثل الحضارة اليونانية

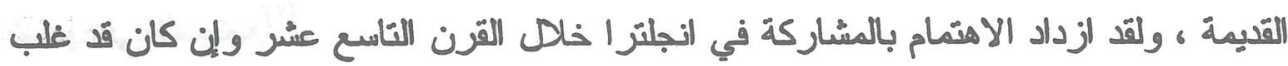

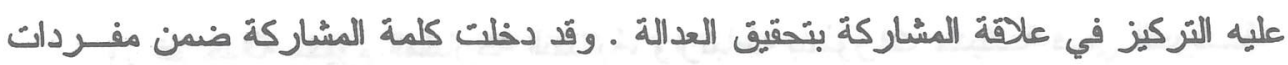

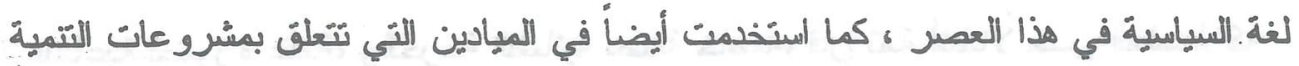

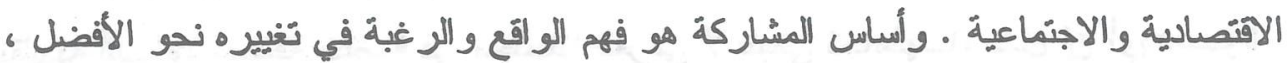

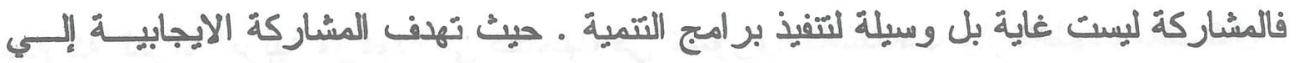

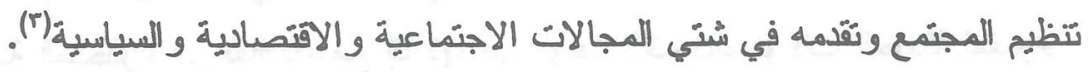

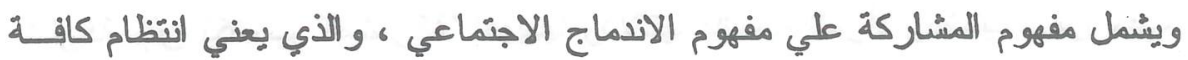

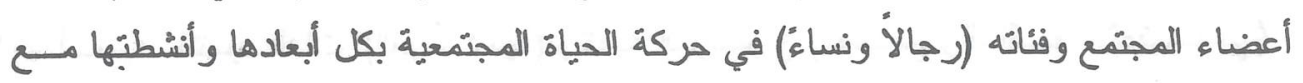

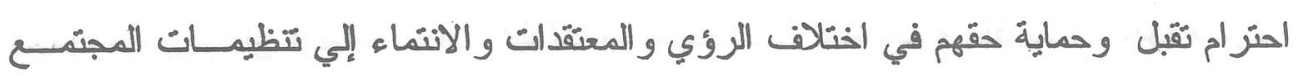

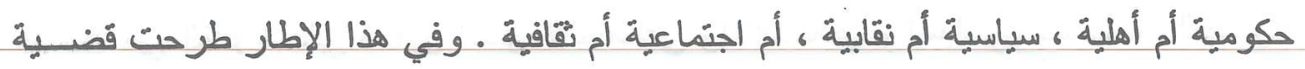

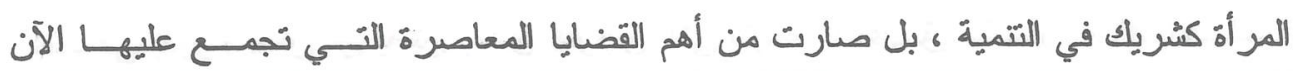

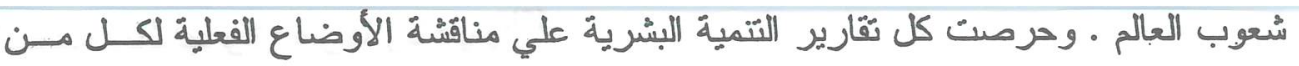
الرجل و المر أة، ودرجة مشاركة كل منهما في التتمية ، بل صار تشجيع المساواة بين الجنسين وتمكين النساء من أسباب القوة أحد الأهداف الإنمائية للألفية الجديدة الأمز الذي أدي في إلي قيّام

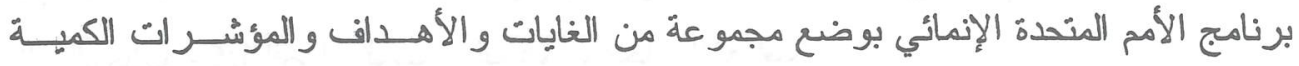

(') www medadcenter.com/Articles/show.aspx?Id=74.

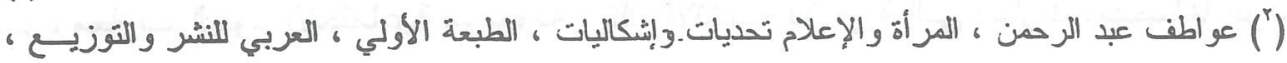

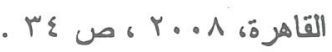

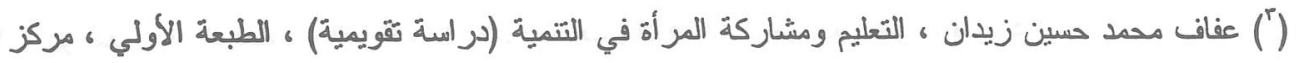

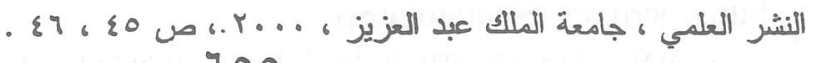




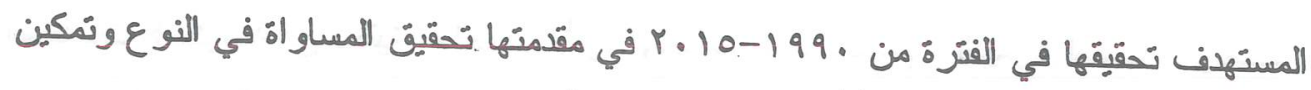
المرأة وتحسين الصحة الإنجابيةُ (1).

إن درجة المشاركة ونطاقها تحدد إلي درجةَ كبيرة توزيع القوة Power في المجنمع

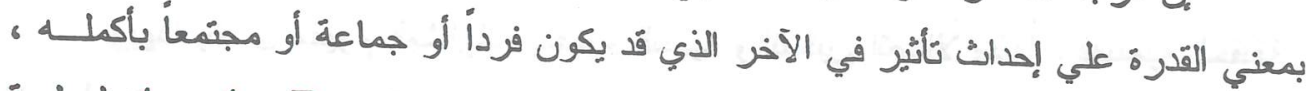

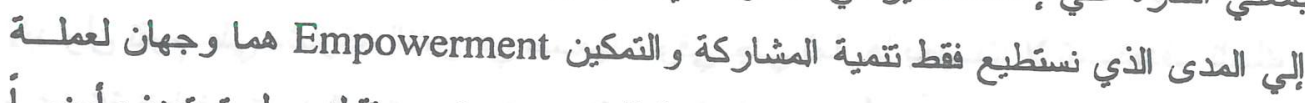

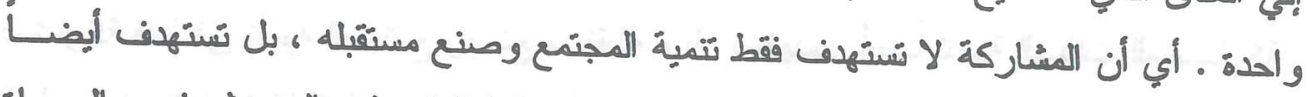

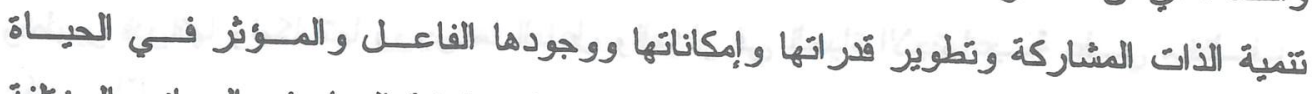

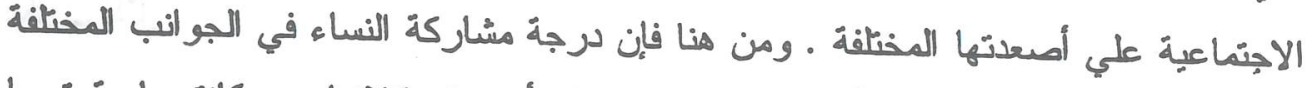

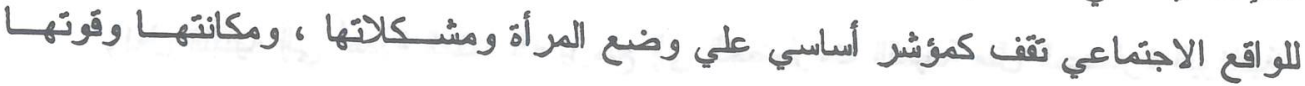

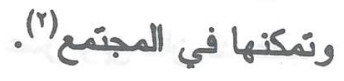

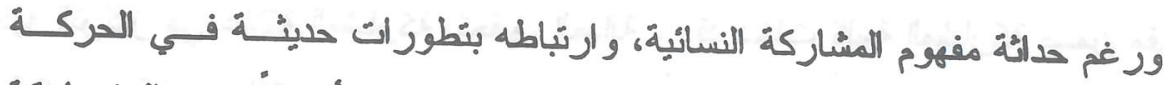

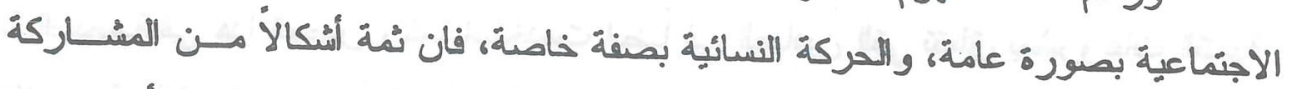

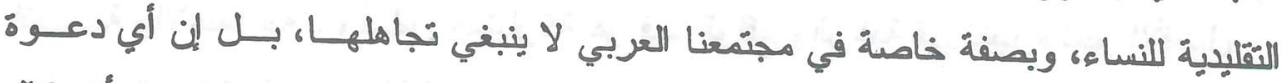

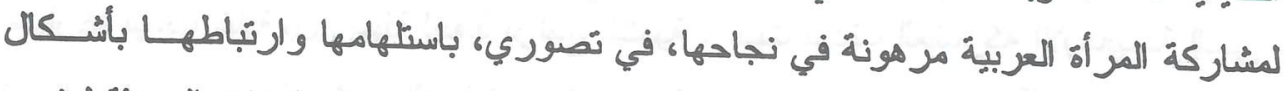

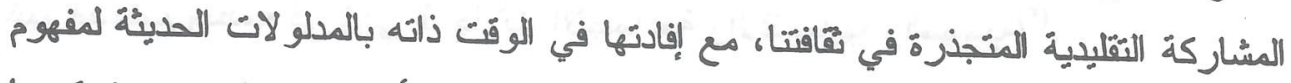

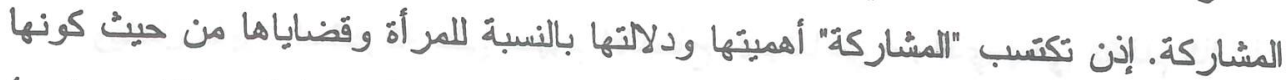

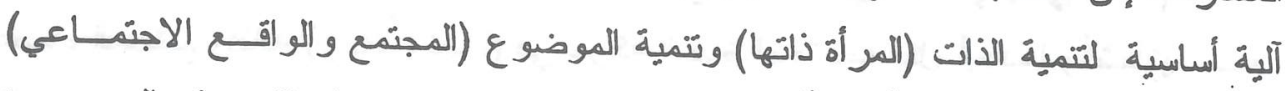

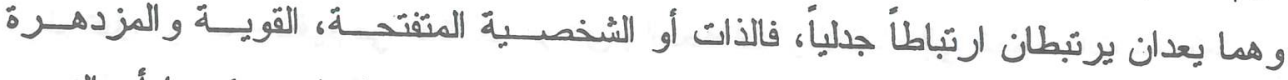

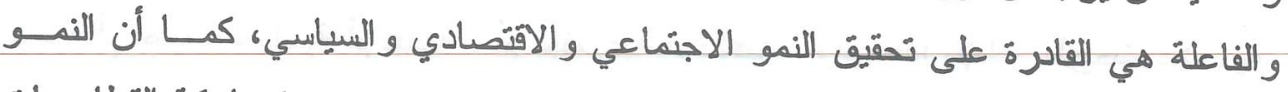

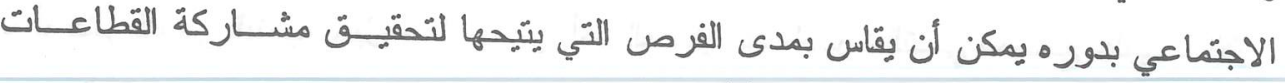

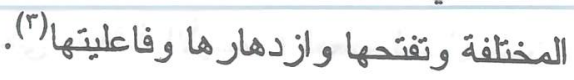

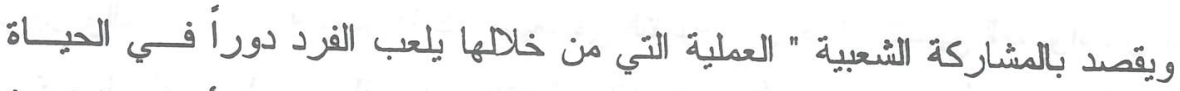
السياسية و الاجتماعية لمجتمعه وتكون لديه الفرصة لأن يشارك في وضع الأهداف العامـــة لاللك المجتمع وكذا أفضل الوسائل لتحقيق و إنجاز الأهداف " . وثمة تعريف للمشاركة السياسية باعنبار ها جزءأ من المشاركة الشعبية ، أشارت إليه

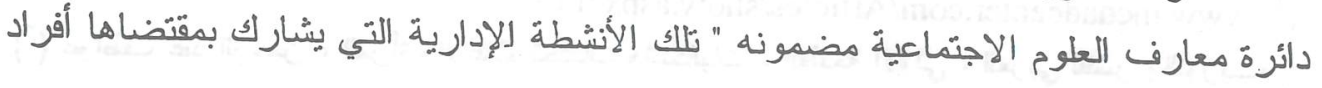

$\left({ }^{2}\right)$ http://pcrp.org/esdarat6.htmi

$\left({ }^{3}\right)$ http://www.ayamm.org/arabic/Marsad/marsad\%201.htm 
مجتمع في الختبار حكامه وفي صياغة السياسة العامة بُكل مباشر أو غير مباشـر أي أنهـا

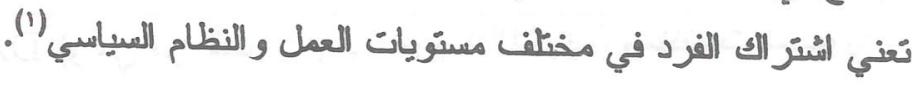

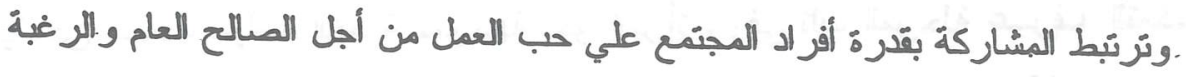

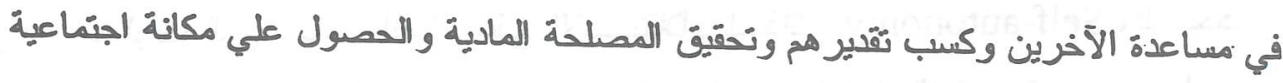

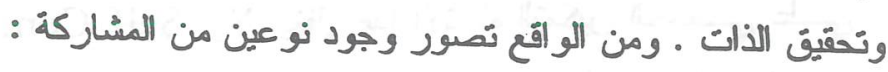

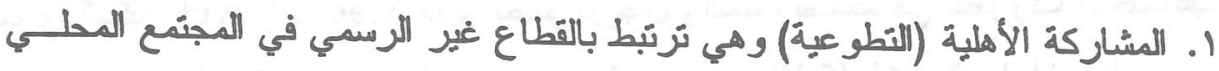

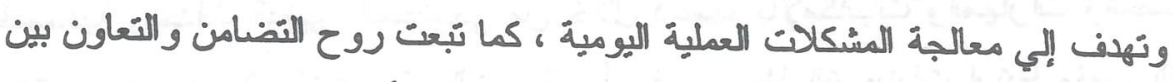

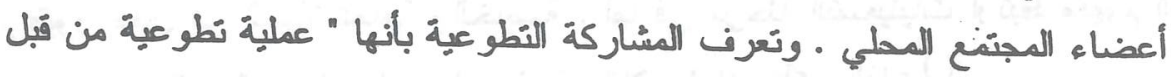

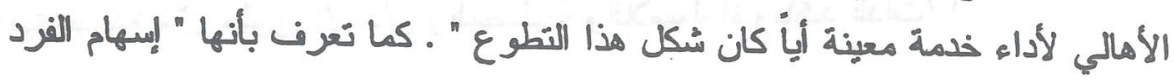

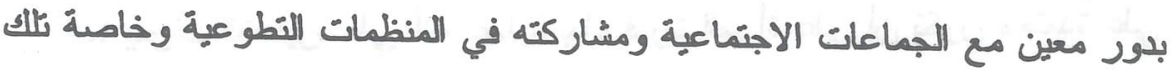

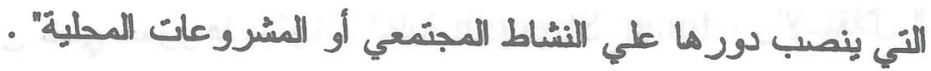

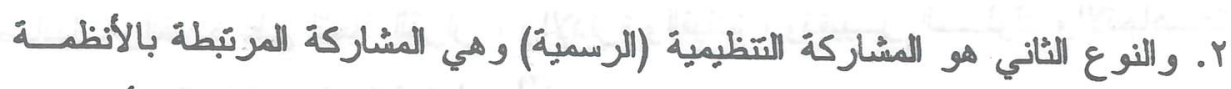

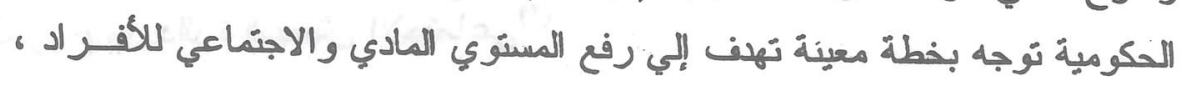

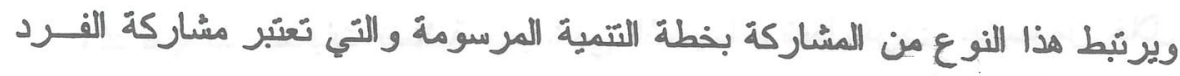

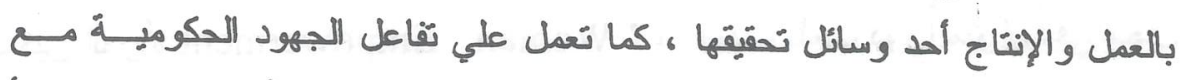

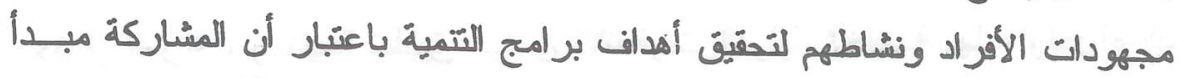

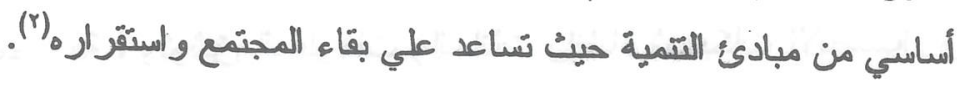
وأخيراً بقدز ما نكون المشاركة التموية للمر أة مرتكزة أساساً علي مهار اتها وقدر اتها

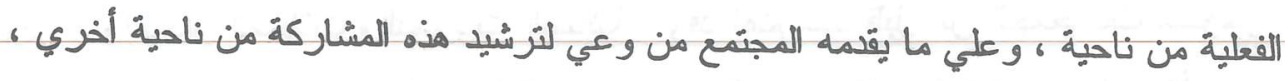

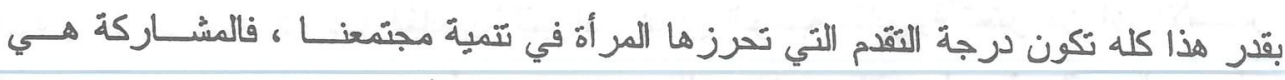

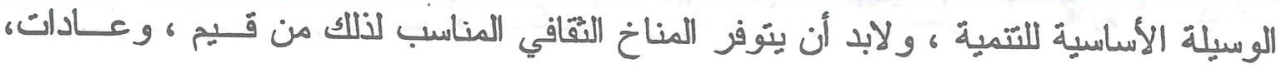

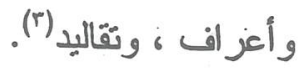

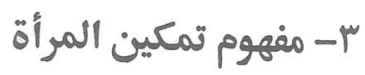

(') عبد الهادي الجوهري ، المشاركة الشعبية دراسة في علم الاجتماع السياسي ، مكتبة نهضـــة الشــرق ،

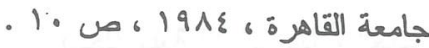

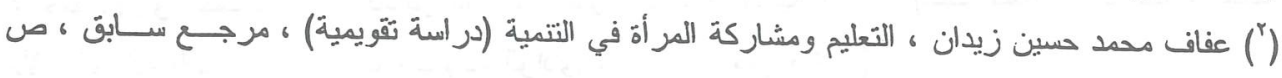




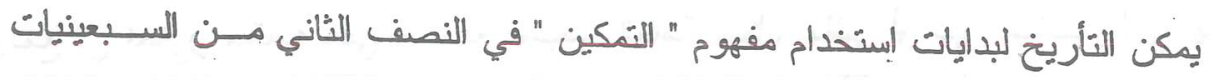

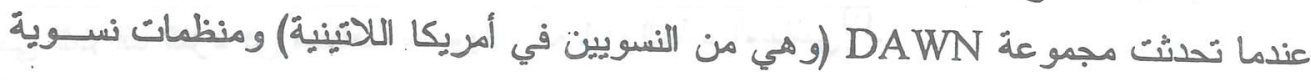

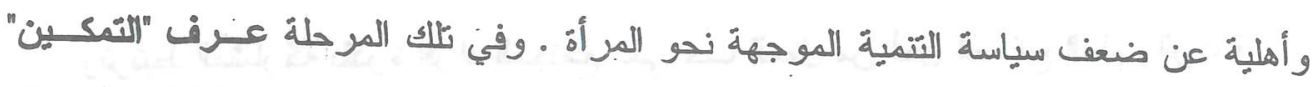

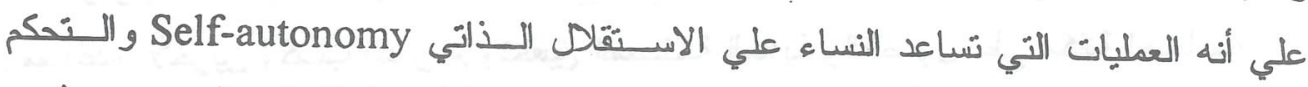
Control

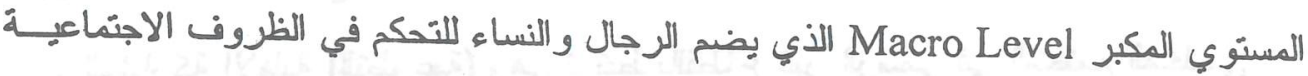

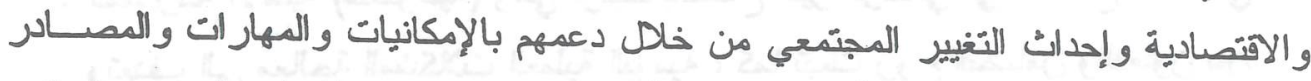

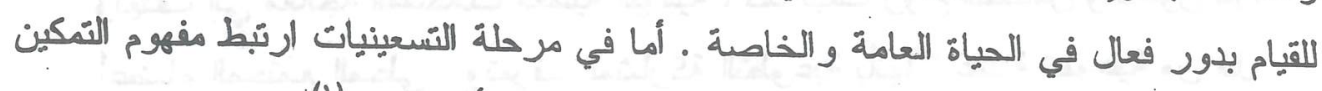

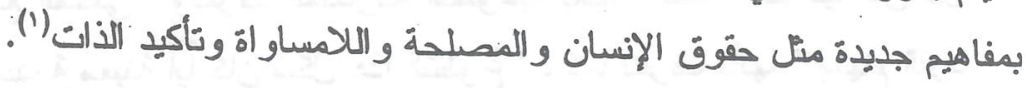

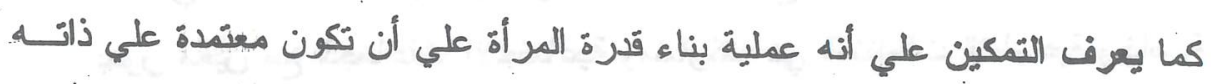

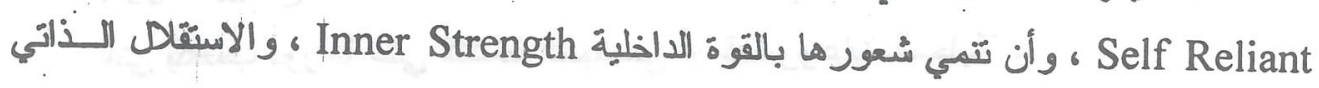

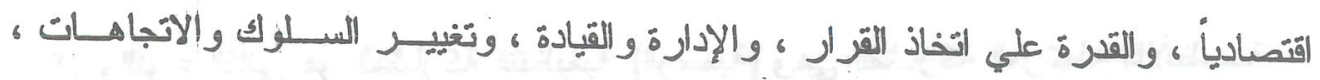

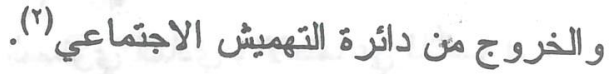

وقد ظهرت جمعيات نسائية جديدة في الثمانينيات تعمل برؤى جليدة من خلآل مفهوم

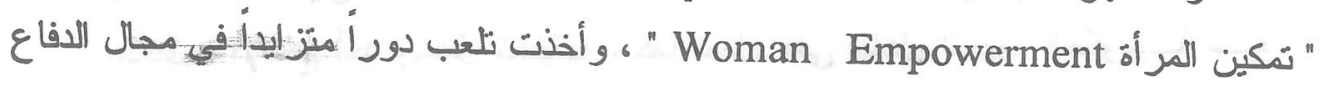

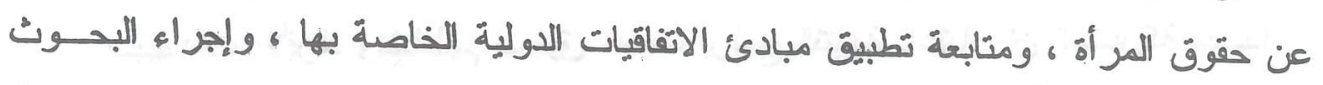

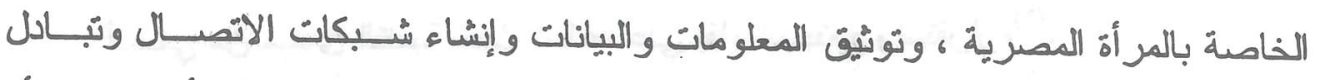

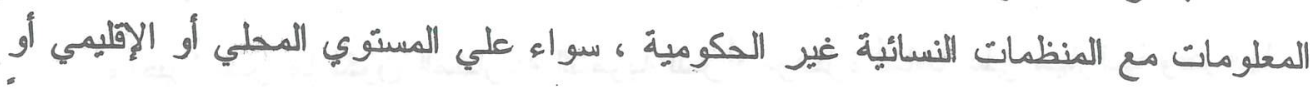

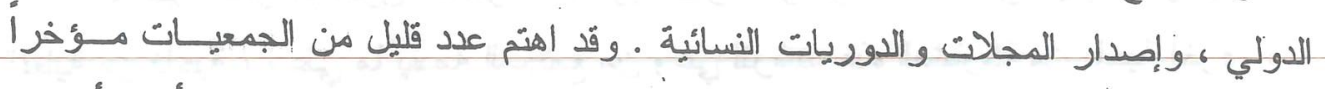

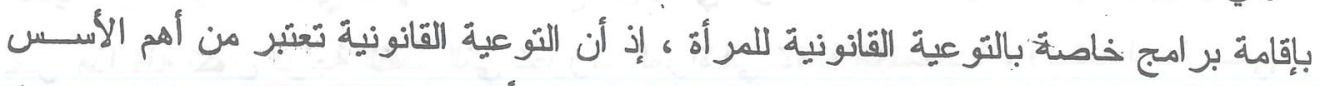

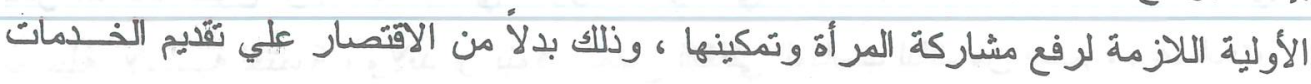

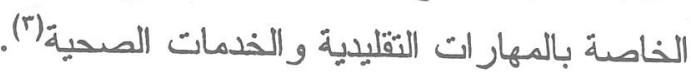

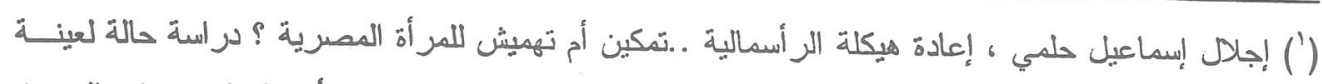

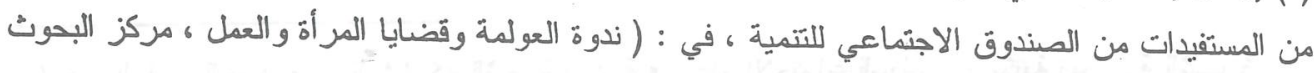

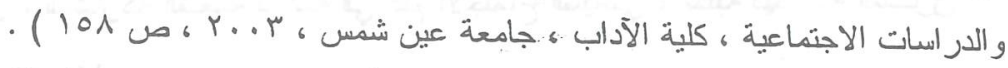

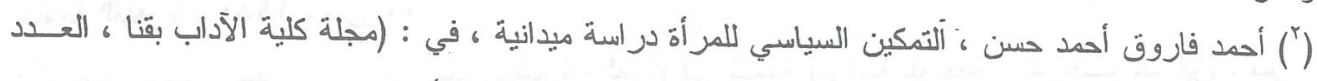

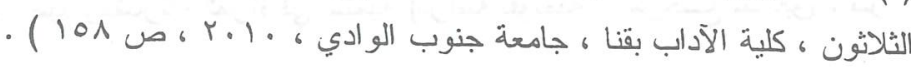

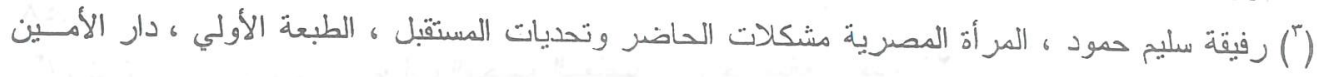

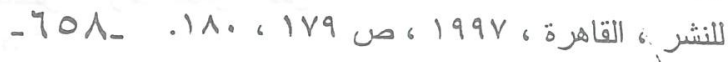




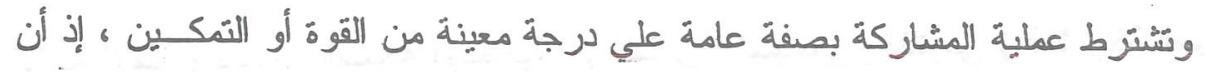

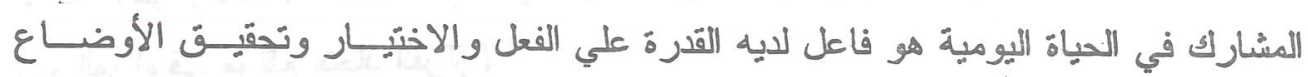
و الأهداف التي يرغبها ، ومن ثم فإن المشاركة الحقيقية نعني وتَفرض درجة الفاعلية وشروط

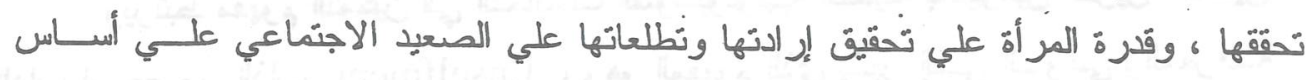
السعي نحو القوة عنصر كامن في الفعل الاجتماعي ، وهو دصدر أساسي لمقاومة التنظيمات

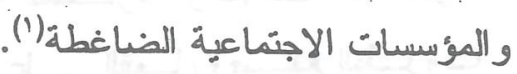

وتحاول المنظمات الألهية وتهذف - ضمن ما نهذف - إلي نمكين المــرأة ، ويعنـي

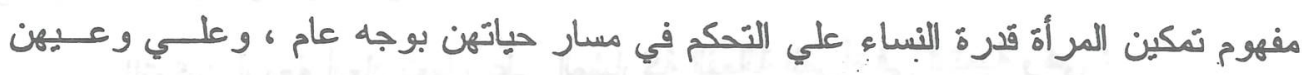

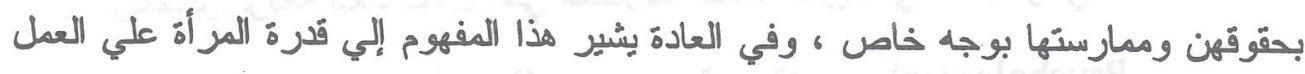

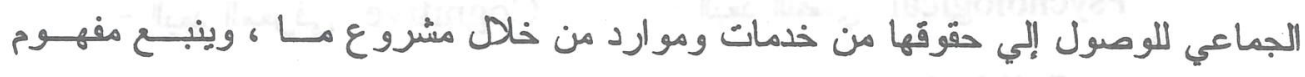

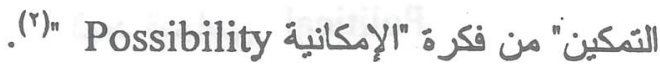

ولذلك فقد حددت الأمم المتحدة أسلوب التمكين باعتباره مدخلاً لتحسين أوضاع المر أة

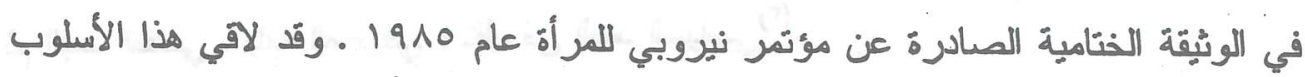

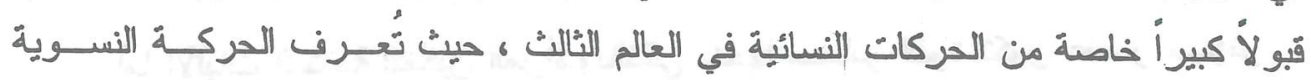

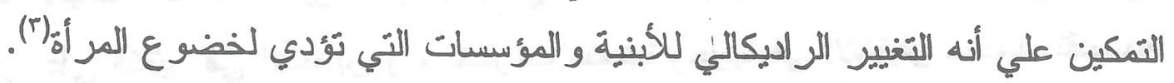

وقد اعندا في المنطقة العربية نشأة المنظمات النسائية المغلقة العضوية على النساء

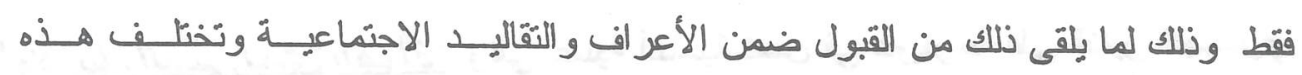

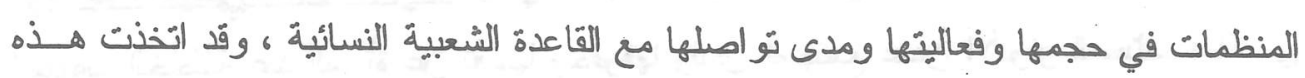

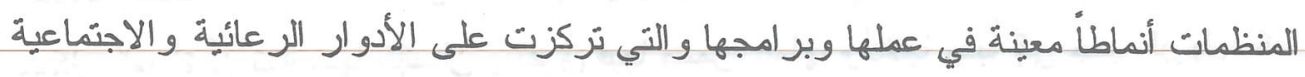

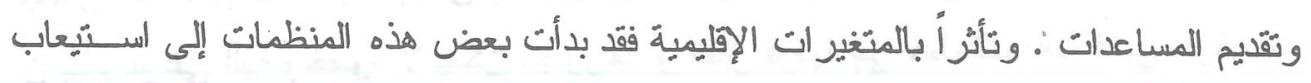

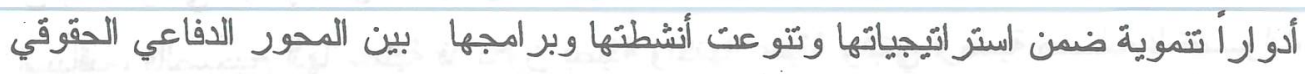

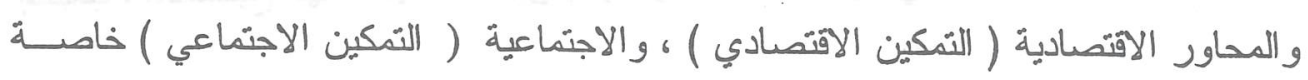

( ${ }^{1}$ ) http://pcrp.org/esdarat6.htm1

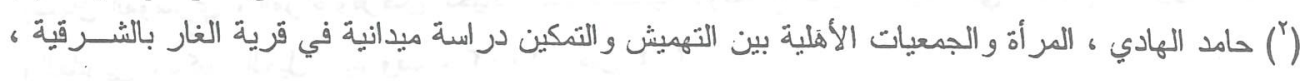

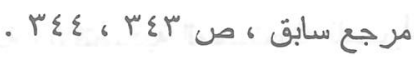

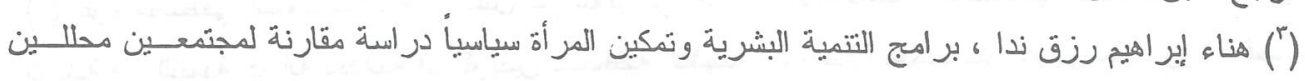

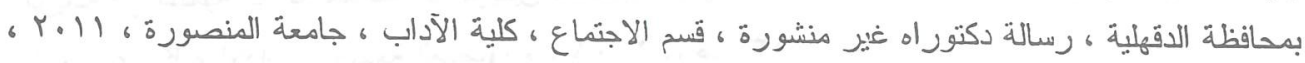
$-709$. 
مكافحة الأميةً وخذمات الصحة الإنجابيةً ، و التمكين السياسي والقانوني ( المشاركة السياسية

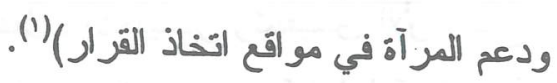

ويرتبط مفهوم التمكين في التخليلات السوسيولوجية الحنيدة بمفهومين آخرين ، تحقين

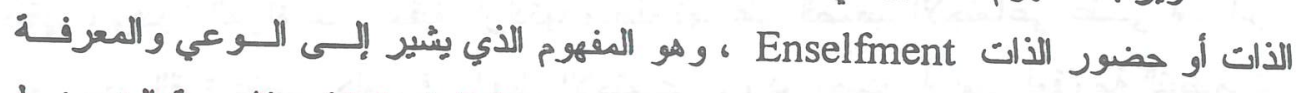

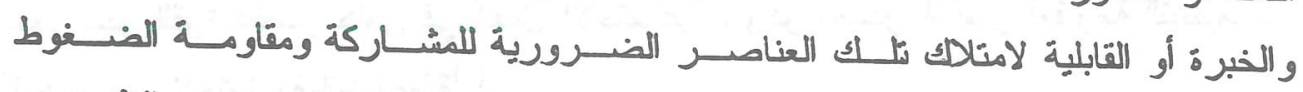

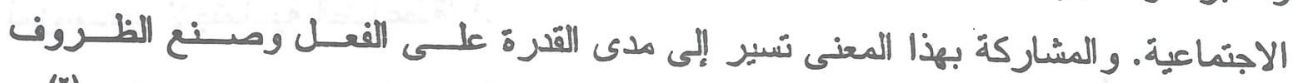

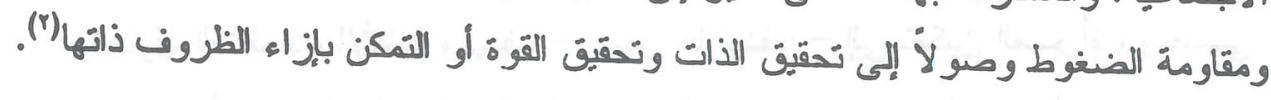
وللتمكين أربعة أبعاد نعمل علي المساركة الفعالة للمر أة في التّمبة وهي :

- البعد المعرفي $\quad$ - Cognitive

- البعد الاقنصادي Economical - البعد السياسي Political وتختلف درجة التمكين باختلاف أبعاده ، حيث نرتفع بين النباء في البعد الاقتصادي تُم البعد النفسي ، بليه المعرفي ، نقل في البعد السباسي (r). أما الآليات المتاحة لتمكين المر أة وبالتالي منحها مصادر القوة لتكون عنصر مــؤرّز

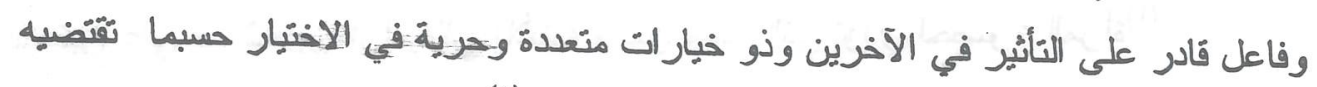
حماية مصالحها الفردية والجماعية فلا بد أن تشمل التالي (8):

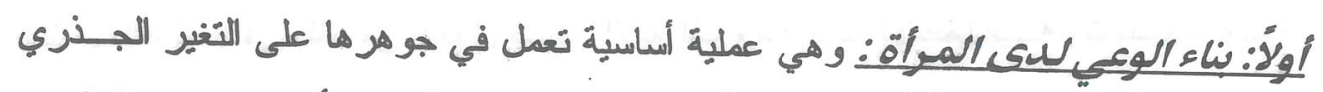

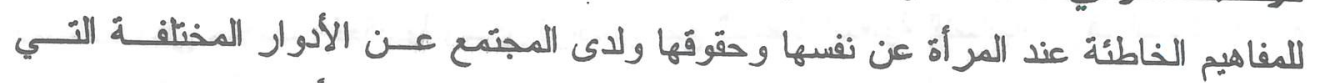

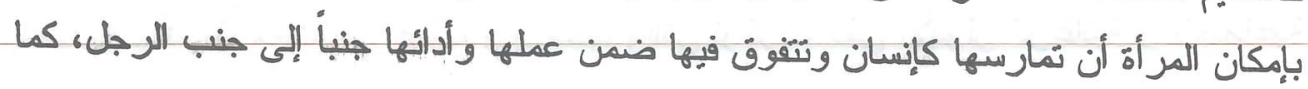

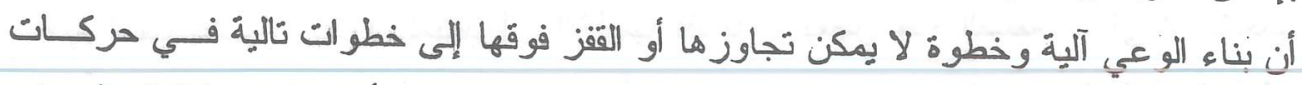

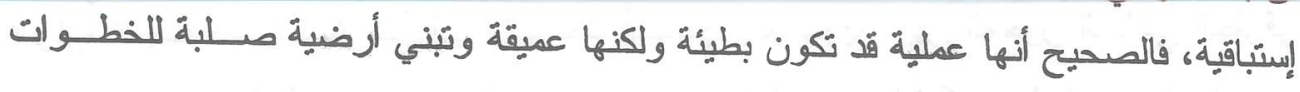

$\left(\begin{array}{l}1 \\ (\end{array}\right)$ http://www.awapp.org/wmview.php?ArtID=1043\&page=5

( ${ }^{2}$ ) http://www.ayamm.org/arabic/Marsad/marsad\%201.htm

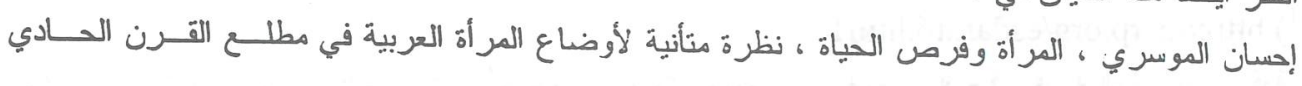

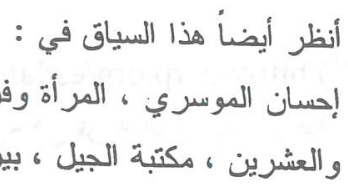

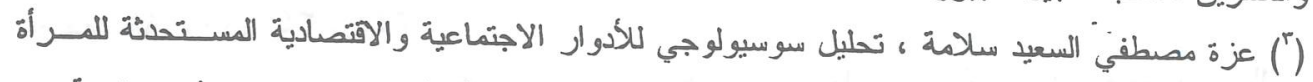

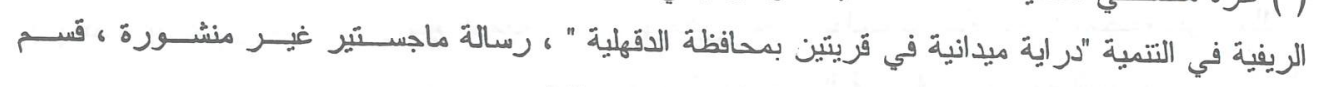

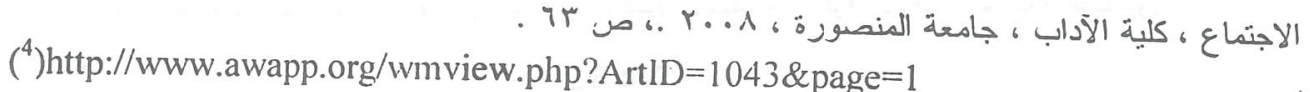
$-77$. 
المستقبلبية الأخرى، كما أن لا فائدة من الحديث عن تمكين المر أة في غياب الوعي لايها كفئة

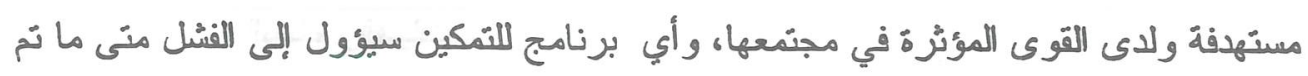
تَجاوز هذه الخطوة ضنمن آليات عمله .

ثانيًا: التأهيل والتلسريب ووناء القلسرات: و هذه خطوة تكمبلية متى ما نشأ الوعي لدى المر أة

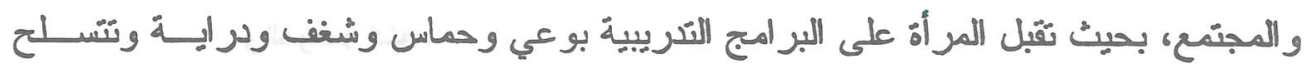
بالقدرات التي تُكنها من خوض ميادين العمل المختلف (').

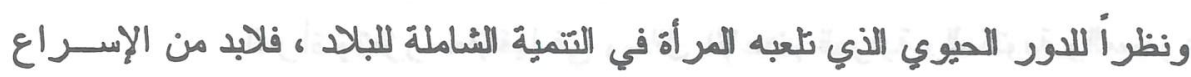

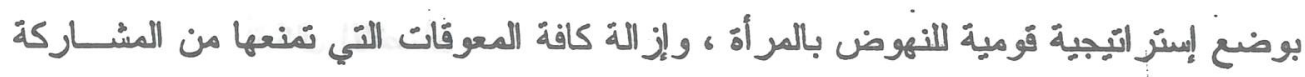

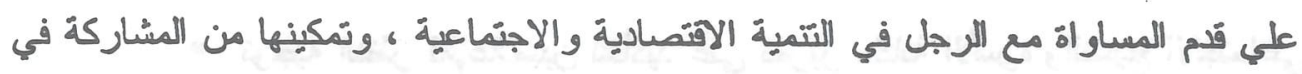

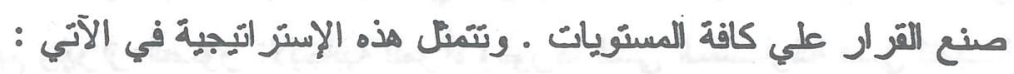

ا. ضرورة اتخاذ قرار سباسي لتعديل كافة الظروف غير المتكافئة بين الجنسين ، بحيث

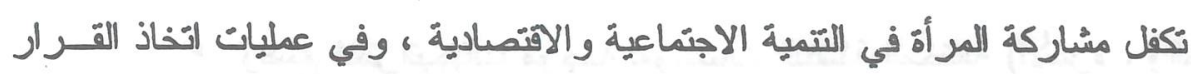
ورسم السياسات .

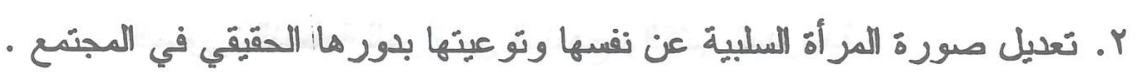

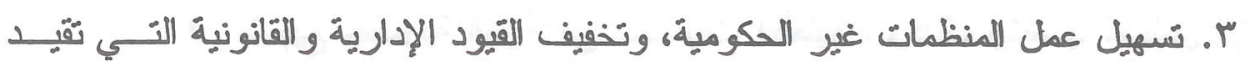

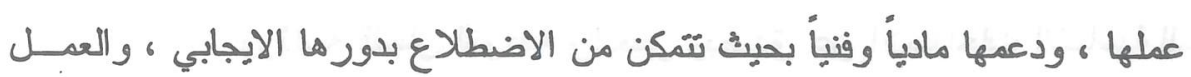

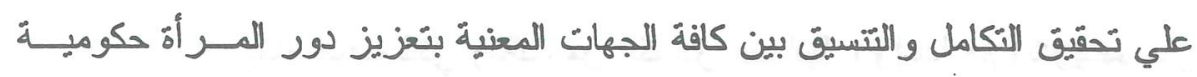

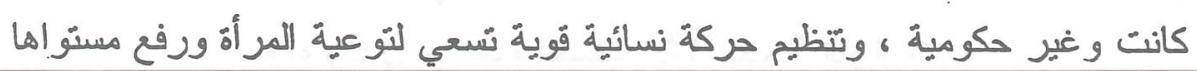

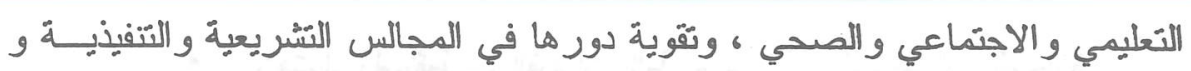

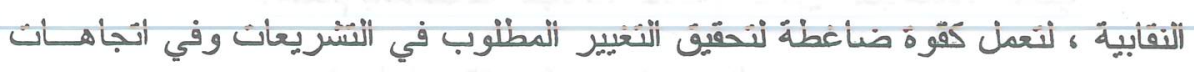
الر أي العام ، وتضنط علي وسائل الإعلام لتنتاول قضايا المرأة المصريةً بجدية فـي

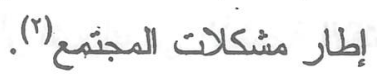
كذلك تلعب الجمعيات الأهلية دور كبير في التعاون مع الحكومة والأحز اب في تمكين

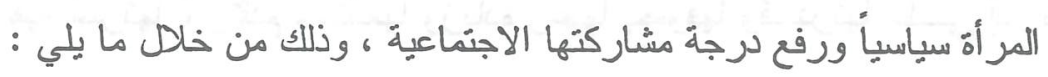

(') http://www.awapp.org/wmview.php?ArtID=1 043\&page=2

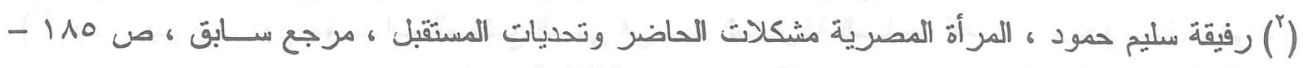


• تسيق جهود هذه الجمعيات مع المؤسسات الرسمية للقضاء علي الأمية بـين .

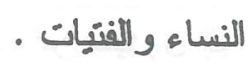
- توجيه الانتباه إلي إز الة الصور النمطية للمراة في المناهج والكتب المدرسية.

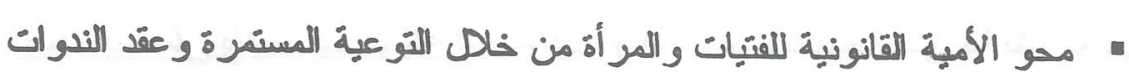

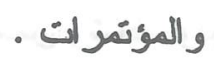

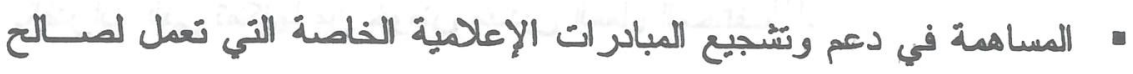

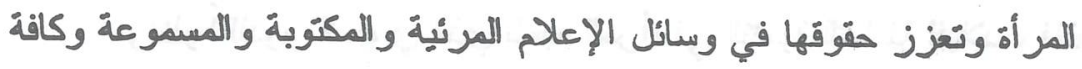

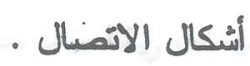
- توجيه النظر للإعلاميين للتأكبد علي تعزيز مكانة الأسرة والنسيج الاجتماعي

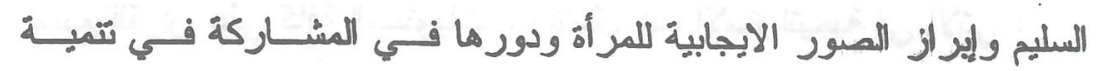

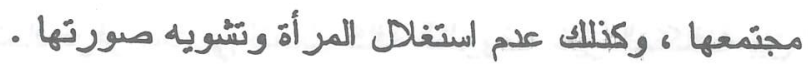

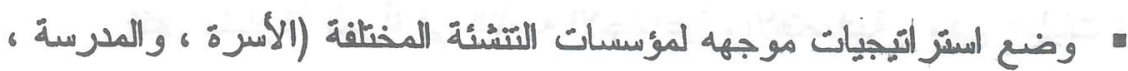

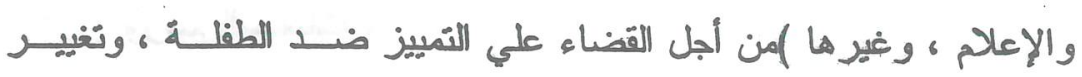
الصورة النمطبة للمر أة في المناهج والكتب المدرسية .

• تشجيع عضوية المرأة في الجمعيات الأهلية ، وكنلك رئاستها لمجلس الإدارة

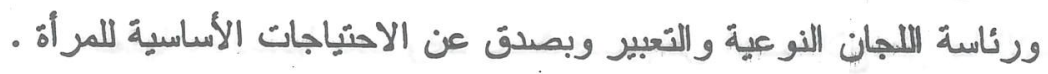

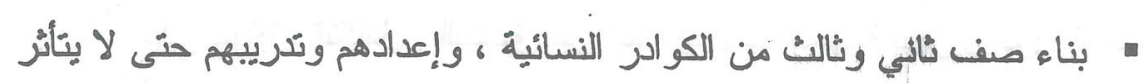

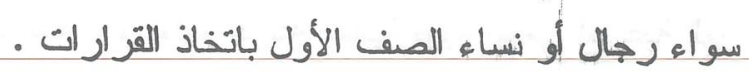
• الاهتمام باستهلياب القيادات الطبيعية داخل المجتعات المحلية .

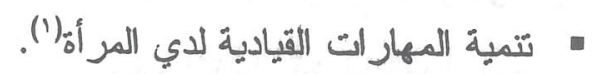

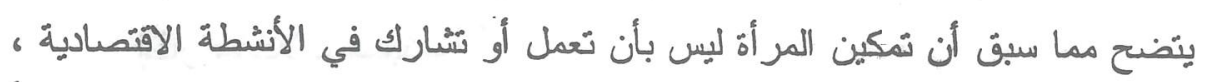

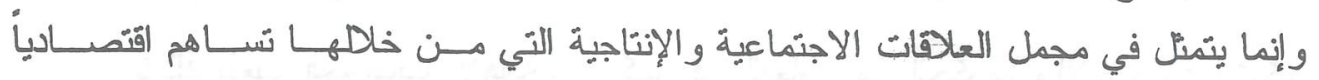

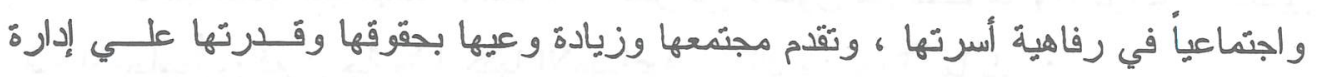


شُئون حياتها العامة والخاصة ، إضافة إلي الثقيبيم والاعتر اف المجتمعي بقدرنها علي إحداث

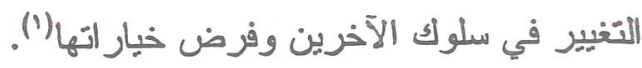
ع- مشاركة المرأة في المنظمات الأهلية غير الحكومية

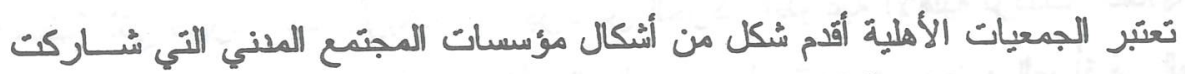

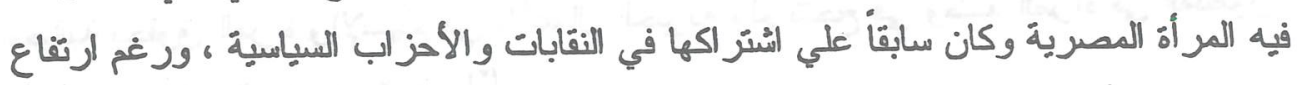

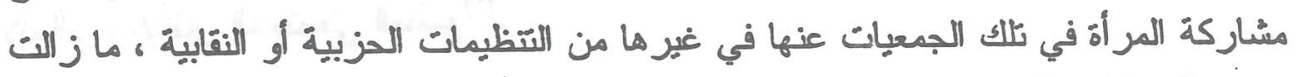

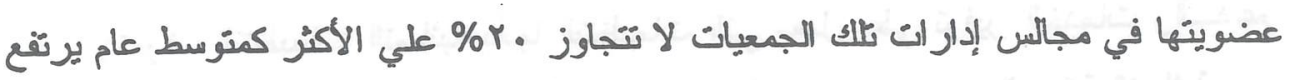

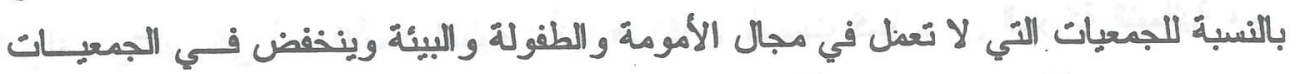
العلمية و النقابية(").

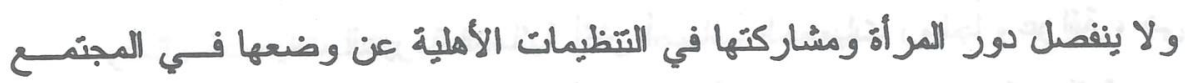

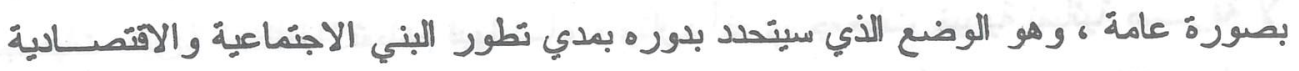

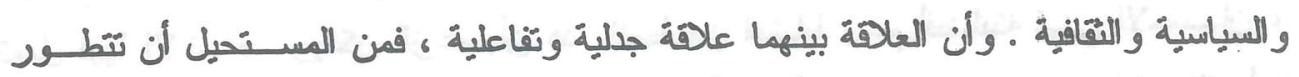

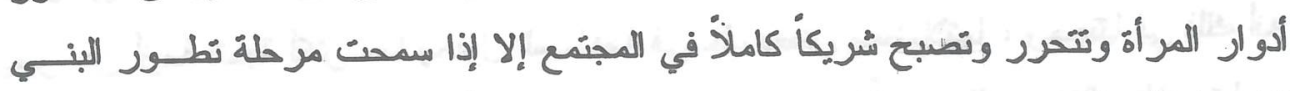

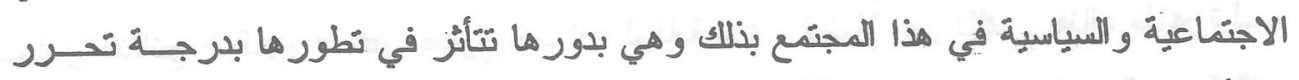

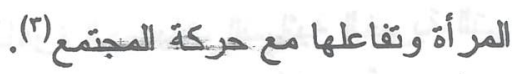

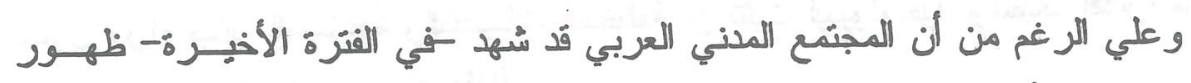

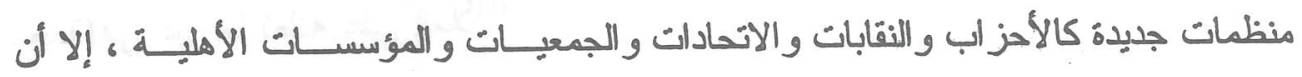

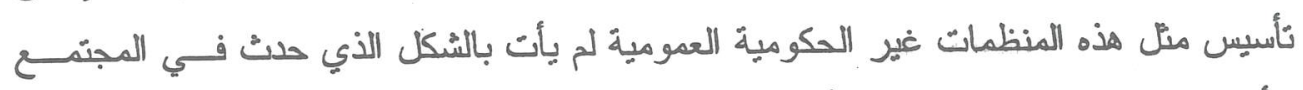

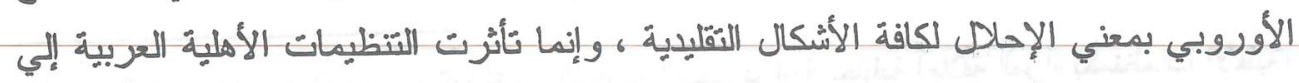

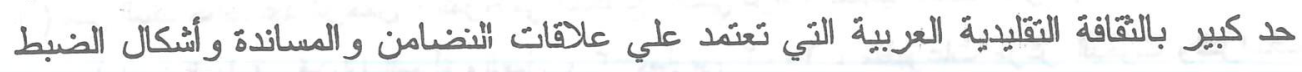

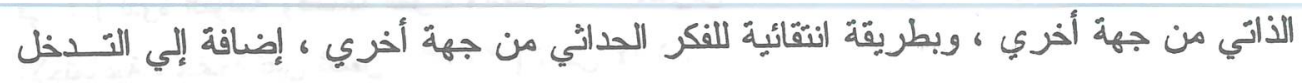

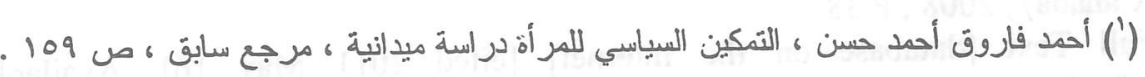

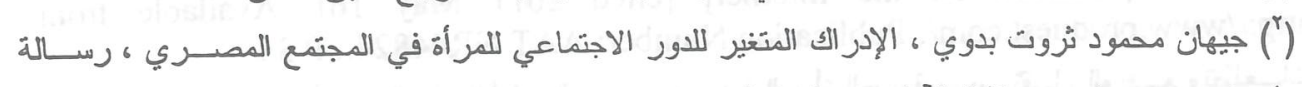

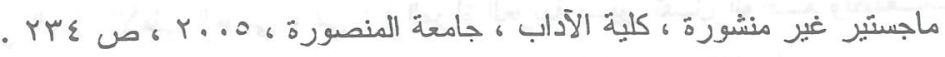
(3) http://www.ayamm.org/arabic/Marsad/marsad\%201.htm 
التشربعي من قَل الدولة ذلاك المتعلق بعملية التأسيس والنشأة ، وسير العــل ، والتفــاعلات المختلفة داخل وخارج المنظمة من جهة ثالثةُ (1).

ومن خلا المراحل التاريخية التي هرت بها التنظيمات النبائية ينضح أن لالتنظيمات

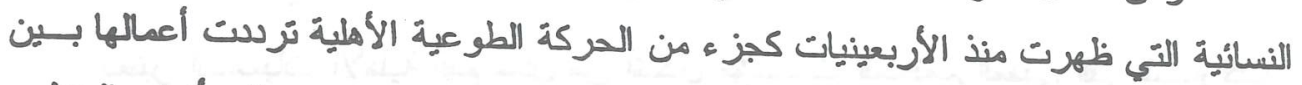

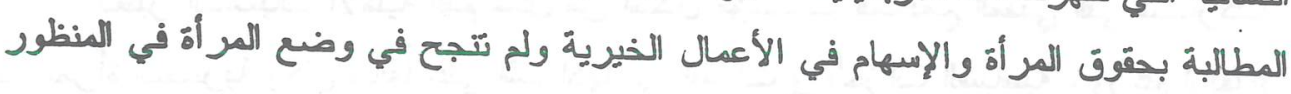
الإنمائي والإطار المجنمعي المنسع (v).

وتعرف النتظيمات النسائبة بأنها التنظيمات التي تعل علي توفير الخدمات والــدعم

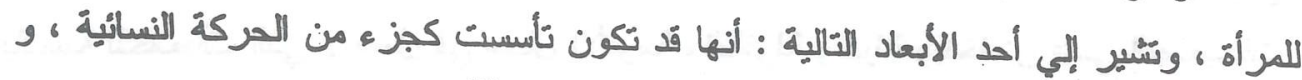
لايها أهداف نسويه ، وأحيرا انعمل علي توجيه القيم والفكر (").

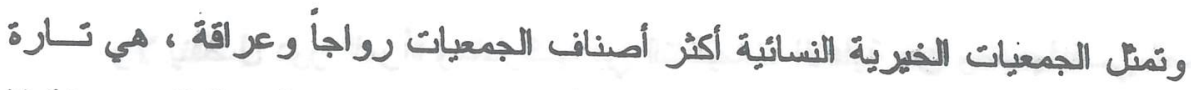

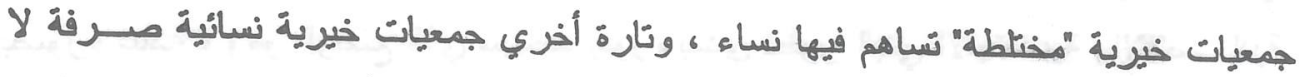

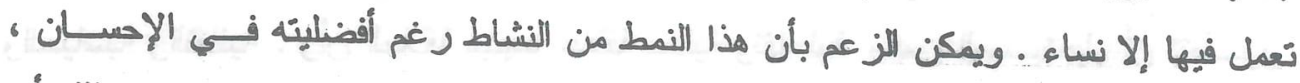

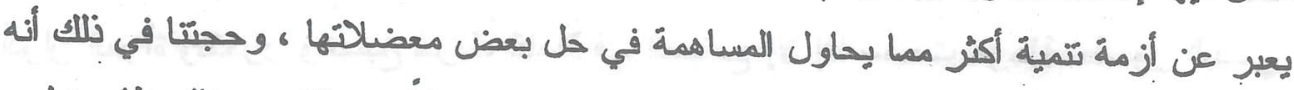

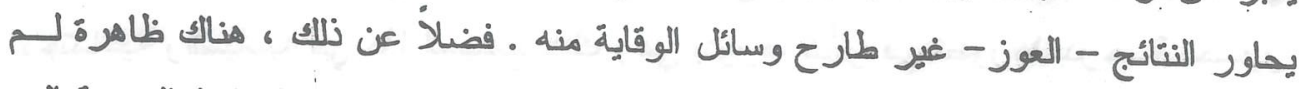

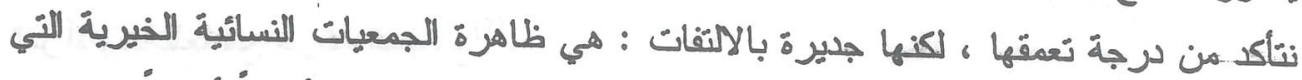

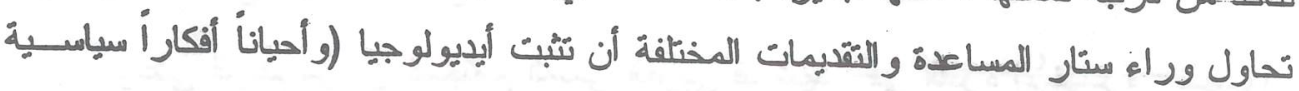

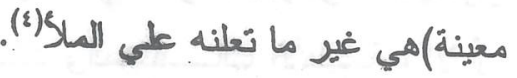

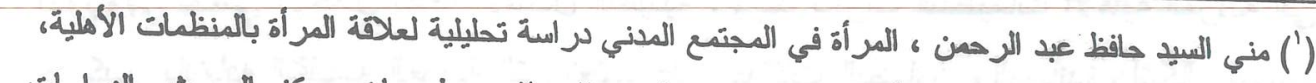

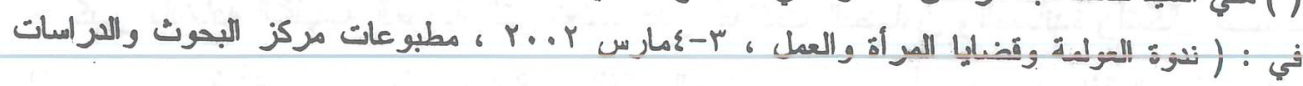

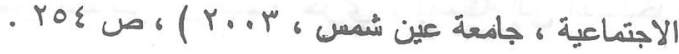

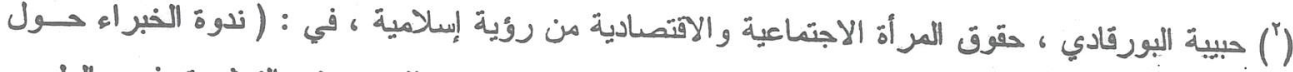

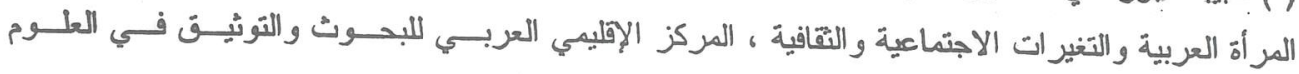

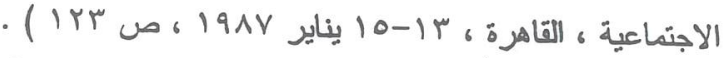

(3) Natalya Timoshkina, Non-Hierarchical Organizing And International Women's NGOs : An Exploratory Study A thesis Submitted In Conformity With The Requirement, the degree of Doctor of Philosophy, Faculty of Social Work , University of Toronto, (Canada), 2008, , P 38

Full Text [database on the Internet] [cited 2011 May 16]. Available from: http://www.proquest.com/; Publication Number: AAT NR44824., P 35.

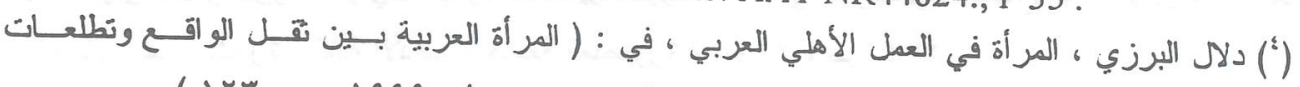

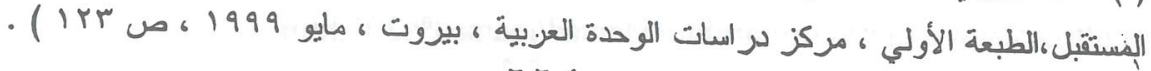


وتعمل التنظيمات النسائبية لصالح المرأة وتقدم الخدمات بما بِــاعد عاتـي تحســين

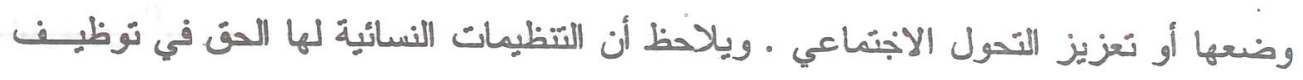

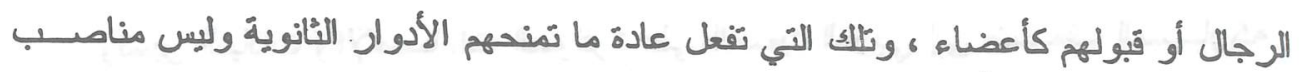

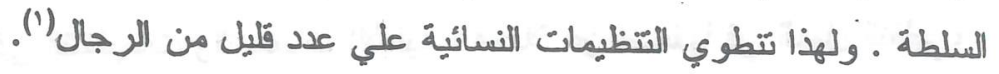

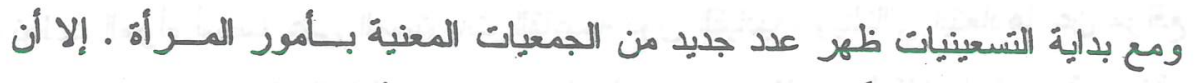

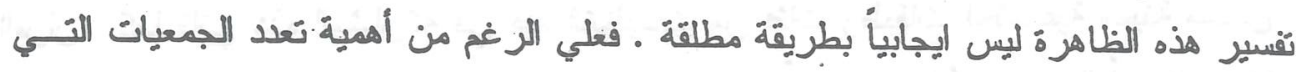

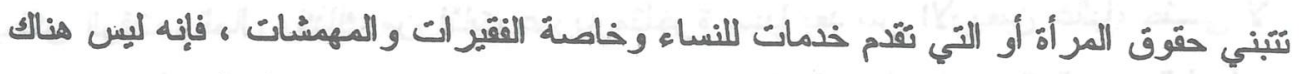

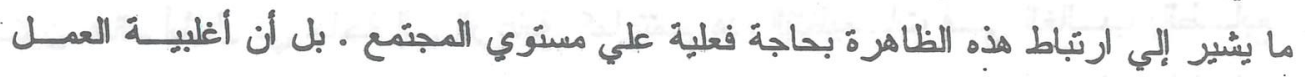

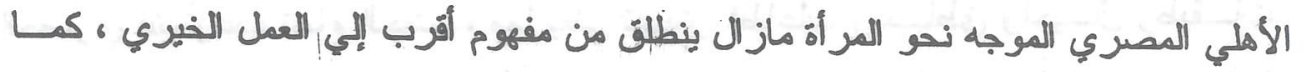

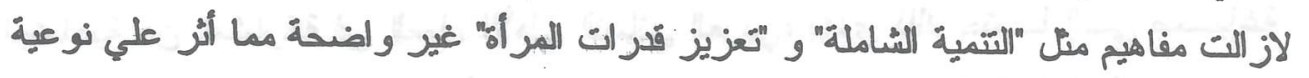

$$
\text { المشُرو عات التي يتم تتفيذهاب(أ). }
$$

و إذا كان إنشاء الجمعيات النطوعية و المشباركة في أنظمنها يمثل أحد الأوجه البـارزة:

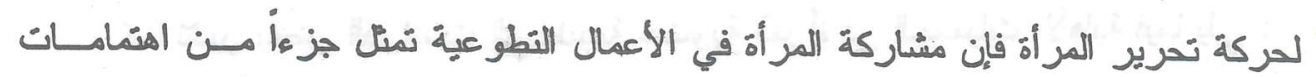

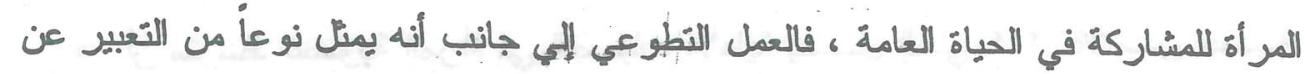

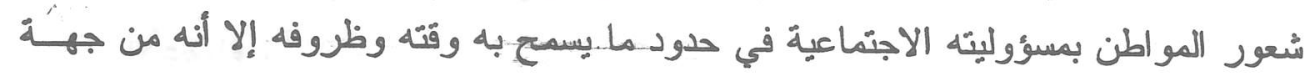

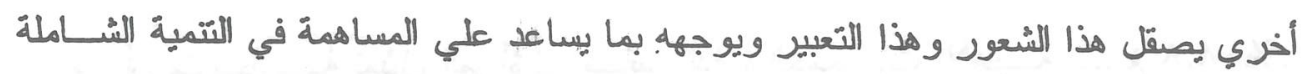

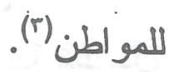

على الرغم من أن مشُاركة المر أة بالجمعليات الأهلية بعد قرارًا فرديا يخضـــع لإر ادة

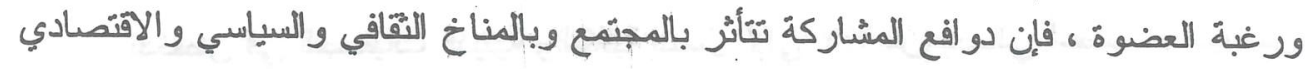

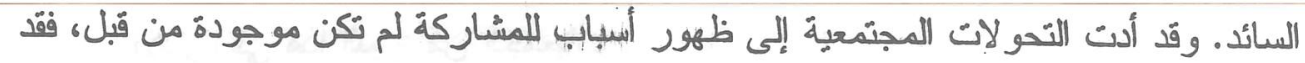

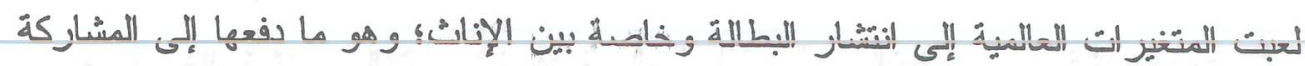

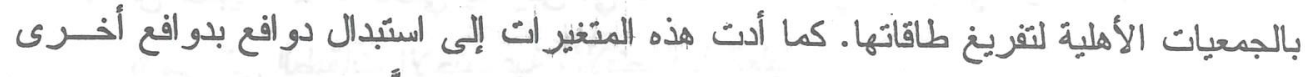

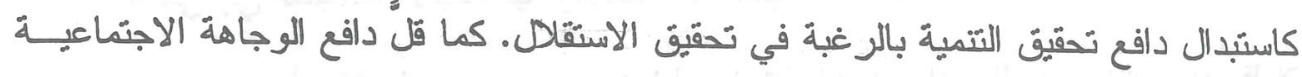

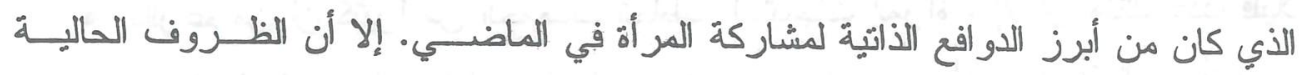

( ${ }^{\mathrm{l}}$ Natalya Timoshkina, Non-Hierarchical Organizing And International Women's NGOs : An Exploratory Study, op.cit, P 36 .

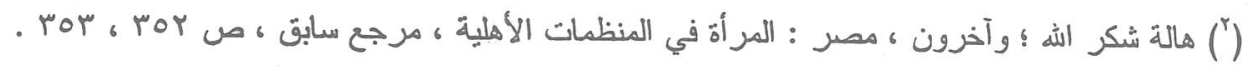

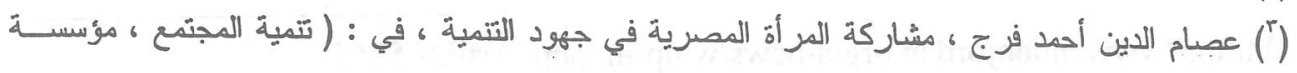




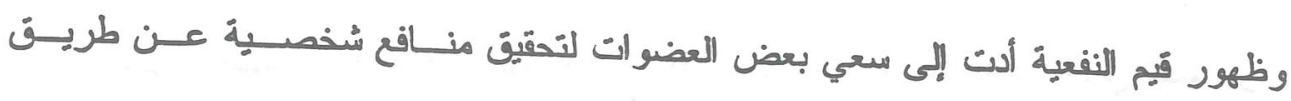

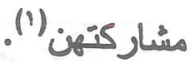

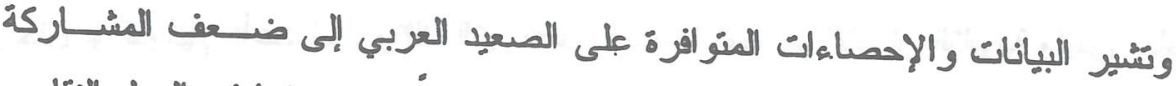

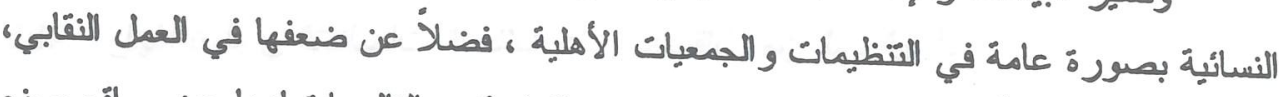

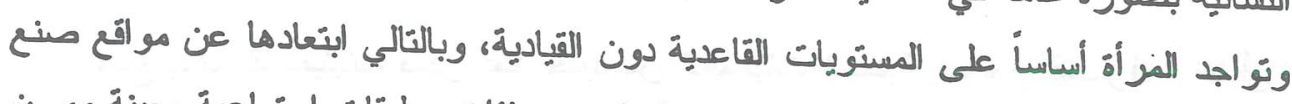

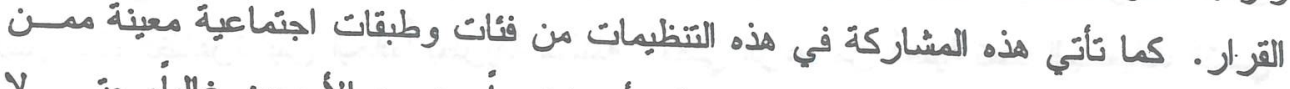

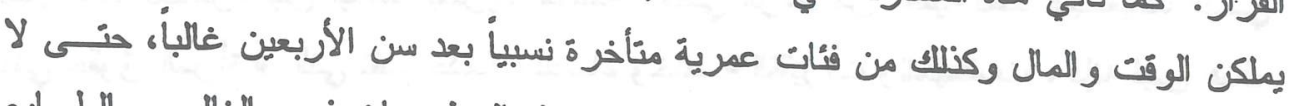

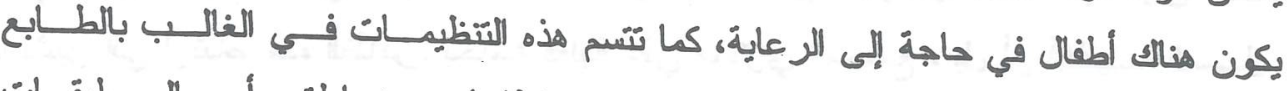

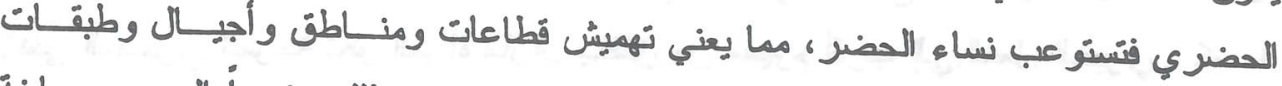

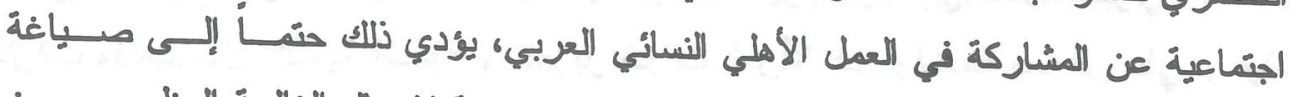

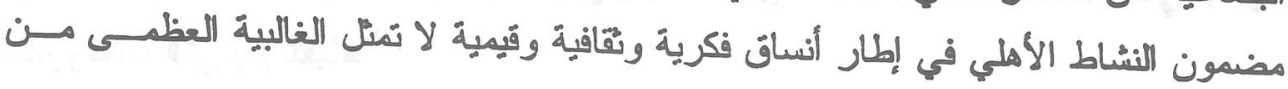

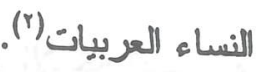

كما تشير بعض الدر المات إلي طبيعة عضوية المر أه في الجمعيات الأهلية فيما يلي :

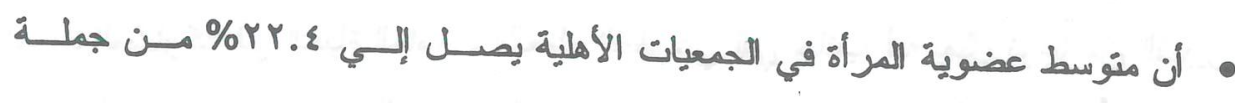
الأعضاء

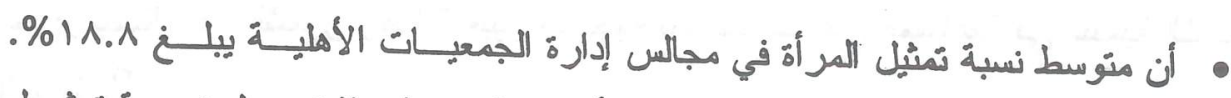

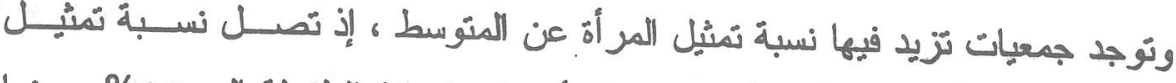

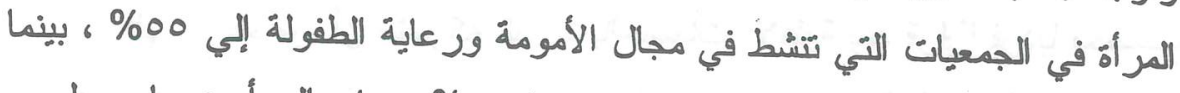

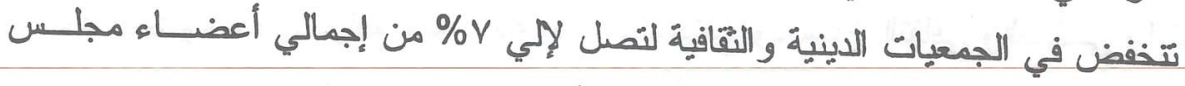

$$
\text { الإدارة في هذا النوع من الجمعيات . }
$$

• أن غالبية النساء اللاثي يشاركن في العمل الاجنماعي التطوعي من خله الجمعبـات الأن

$$
\text { تتنمي إلي الطبقات الاجنماعيةٌ و الاقتصادية العليا ـ }
$$

بالرغم من أن كثيراً من الجمعيات تخاطب احتياجات المرأة ، إلا أن هناك عدداُ قليلاً

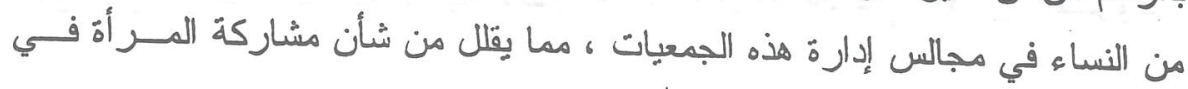

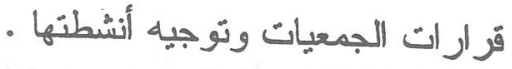

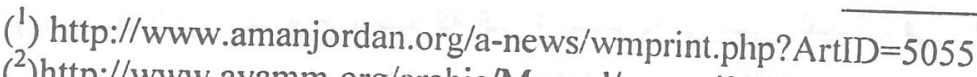

$\left.{ }^{2}\right)$ http://www.ayamm.org/arabic/Marsad/marsad\%201.htm 


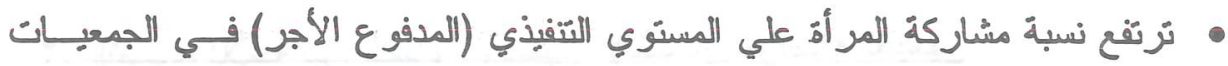

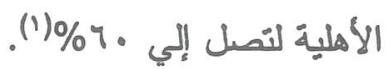

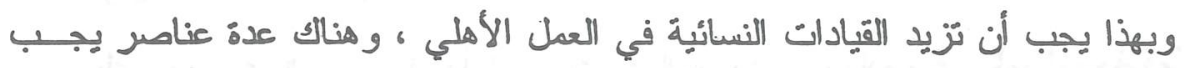
تو افر ها حتى يكون هناك قيادة ، منها :

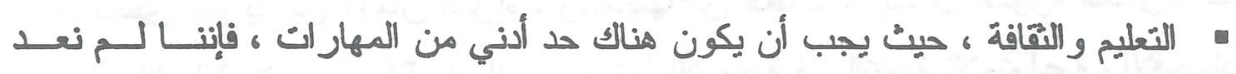

نتحدث عن القر اءة والكتابة فقط ، بل تبقي المهارات من المعوقات في طريق القعيادة .

- الخبرة والممارسة ، وأن تكون هناك ممارسة ونوع من التجارب والتقّيبه. .

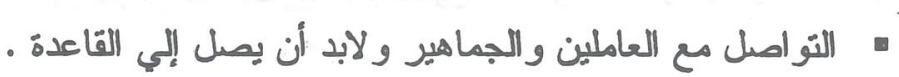

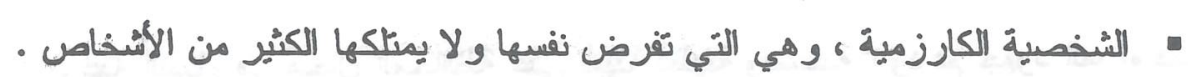

الإيمان بالعمل الاجتماعي ، و إذا لم يتم عشق العل الاجتماعي لن يكون هناك إيتاج •

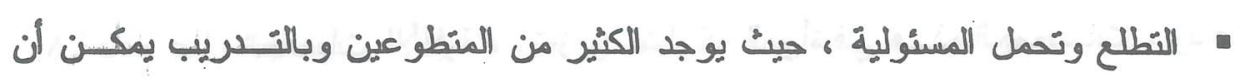

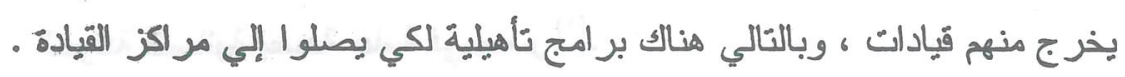

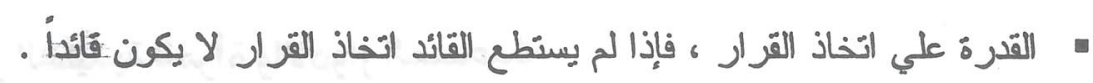

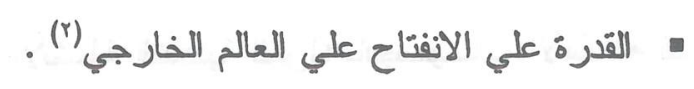

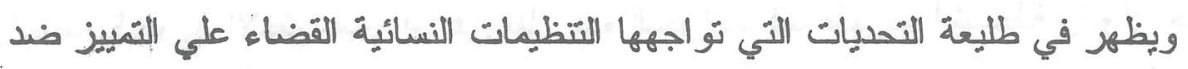

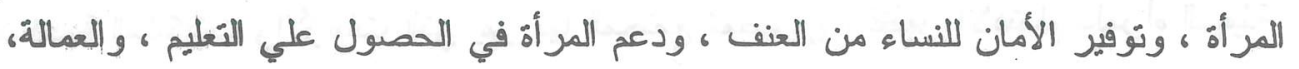

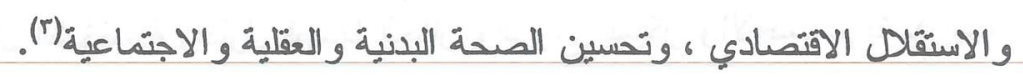

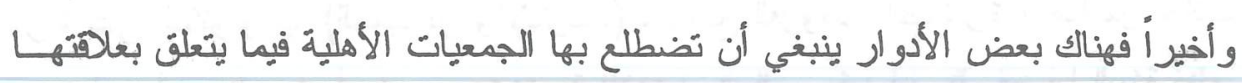
بالمر أة :

ا. المساعدة في تخفيف حدة الفقر ، وزيادة قدرة المر أة علي إيجاد مصادر جديدة للاذل.

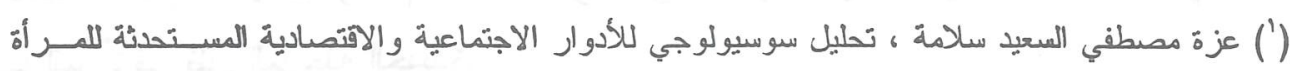

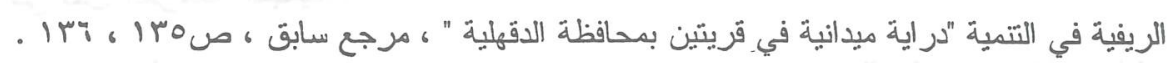

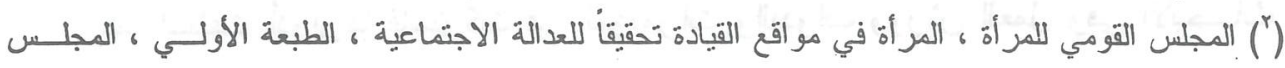

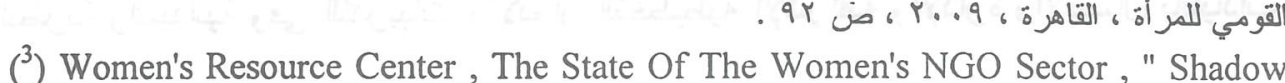
Report Submitted To The United Nations Committee On The Elimination Of Discrimination Against Women (CEDAW) In Response To The United Kingdom's $6^{\text {th }}$ Periodic Report, April 2008, P5" . - 77V_ 
Y. النصدي للأمية بين النساء ، وتمكين الإناث من مواصبلة تعليمهن • r. بوفير الخدمة الصحية الشاملة للمرأة .

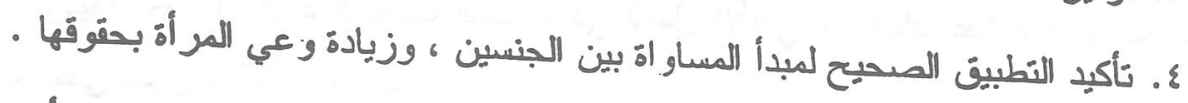

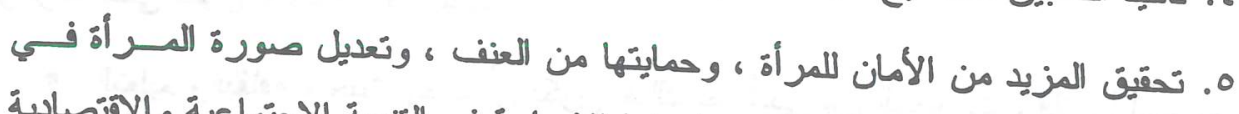

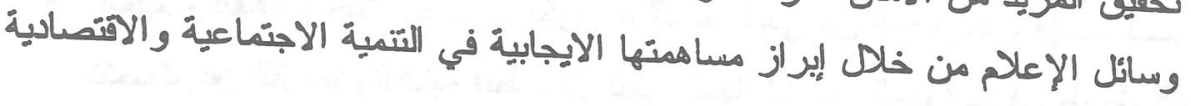

والثقافية .

7. دعم مشاركة المرأة في القرارات الأسرية ، وتعميق المشاركة السياسية والمجتمبِــة . للمرأة .

V. توعية النساء في مجال المحافظة علي البيئة نظيفة وصحية ، ودعم جهود المرأة فــي هذا الجبال .

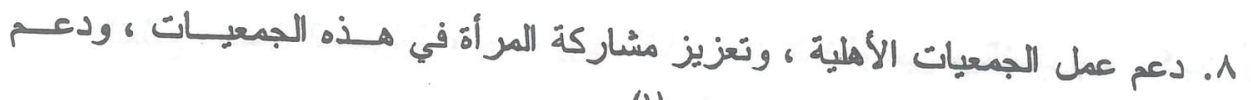

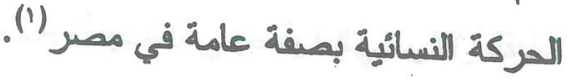
ه- الأدوار التقليدية للمرأة والأدوار المستحدثة

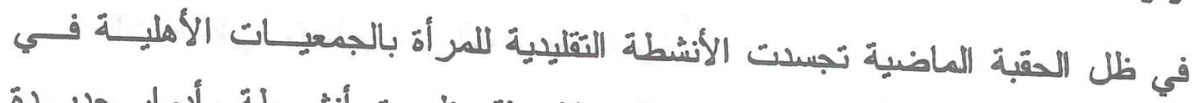

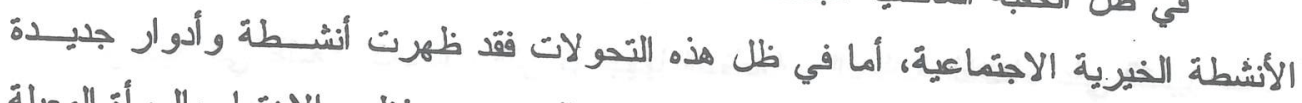

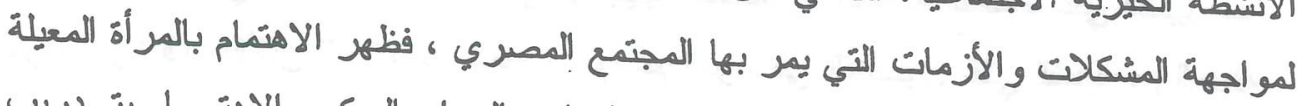

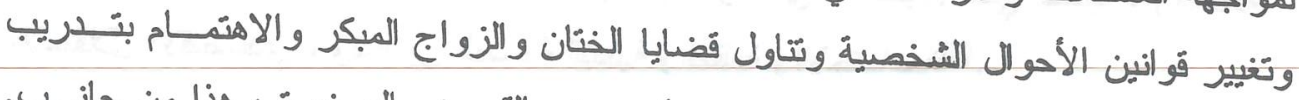

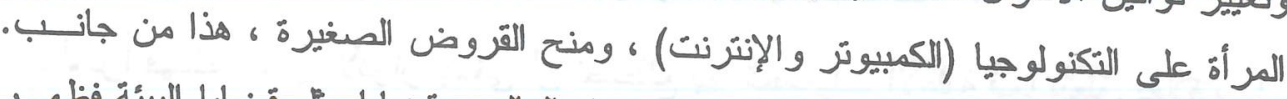

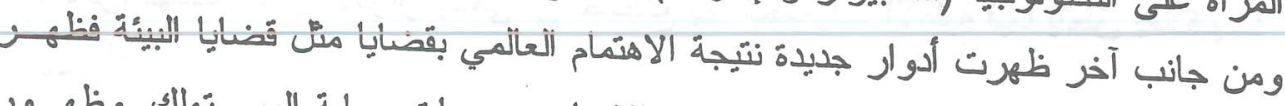

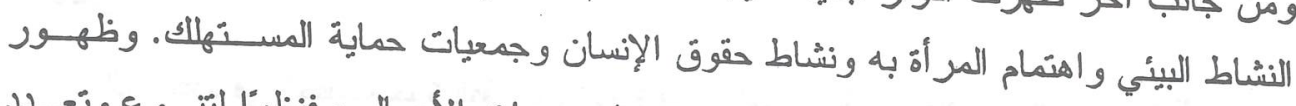

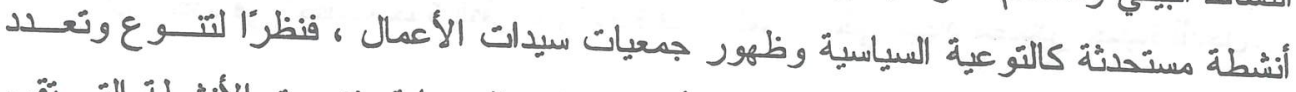

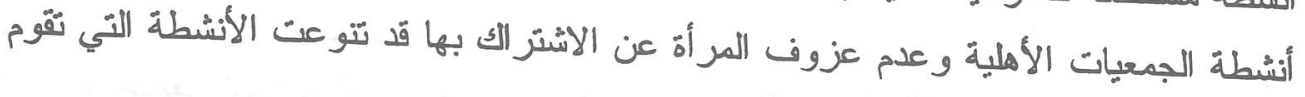
بها المرأة في ظل المرحلة الجديدة.

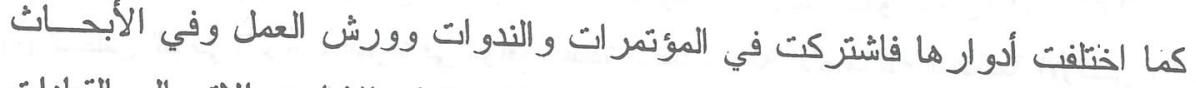

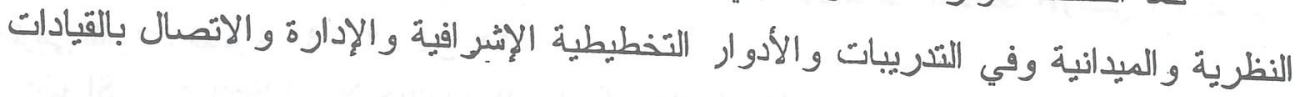

(') أحمد زايد ؛ و آخرون ، المرأة وقضايا المجتمع ، مركز البحوث والدراستات الاجتماعية، كليــة الآداب ،

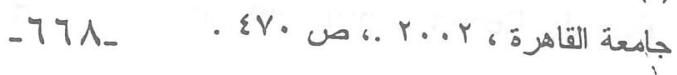




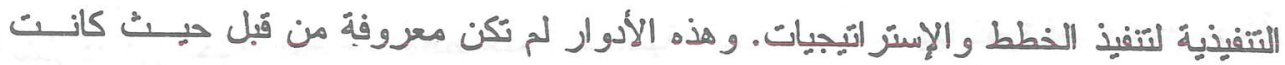

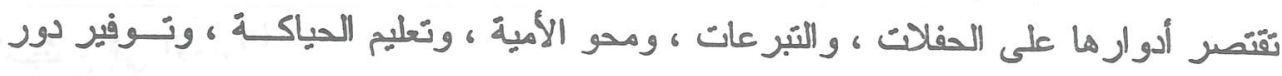

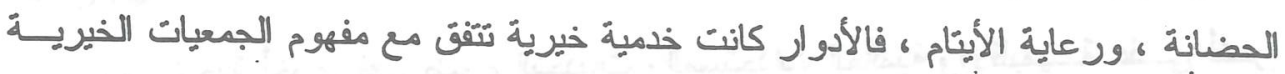

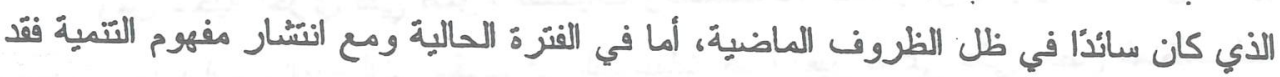
تغيرت الأدوار التي لتعبها المرأة(1). ثالثاً : تأثير العولمة علي مشاركة المرأة في العمل الأهلي

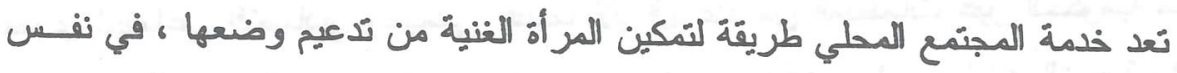

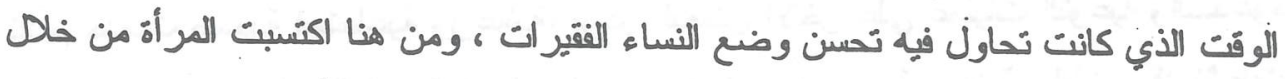

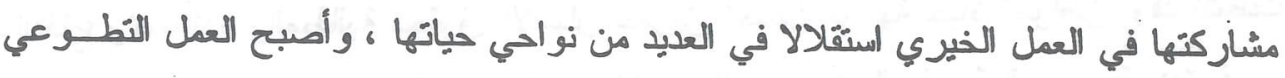

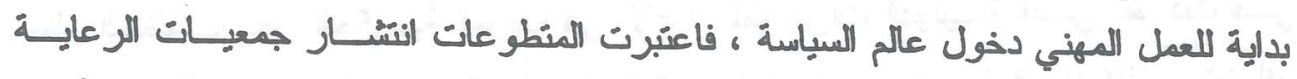

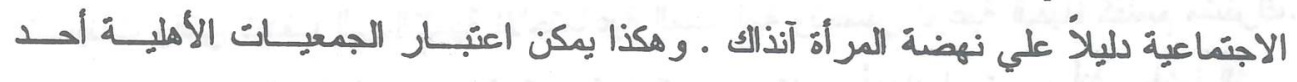

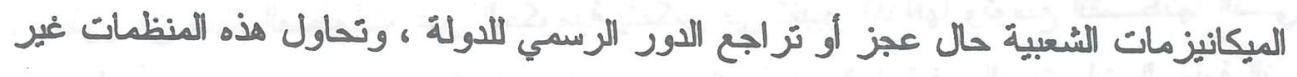

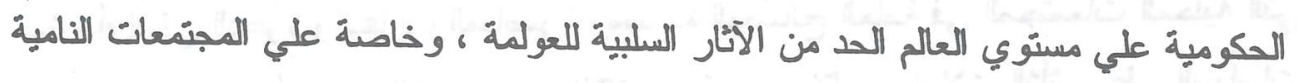

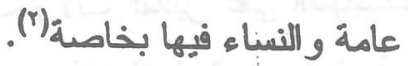

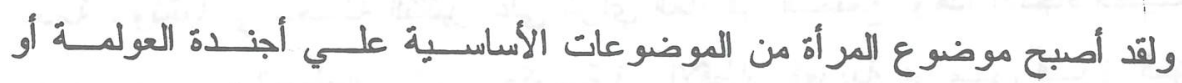

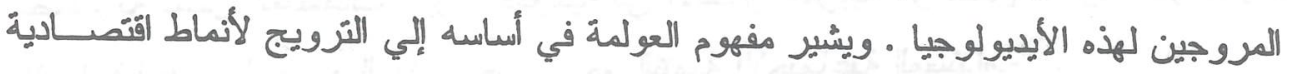

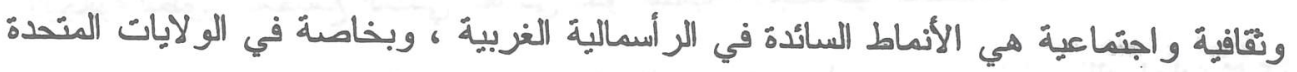

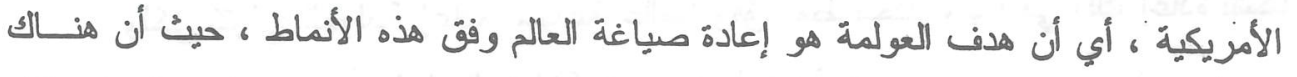

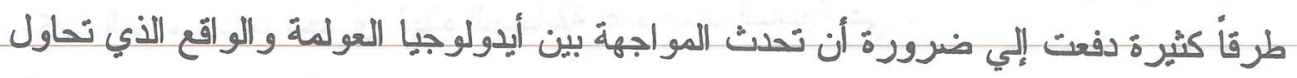

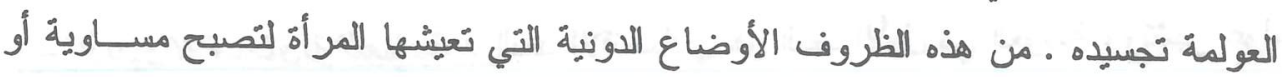

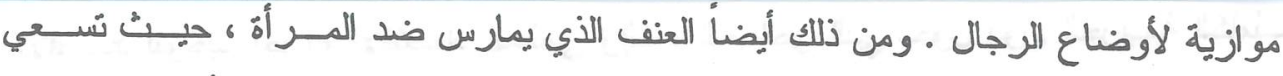

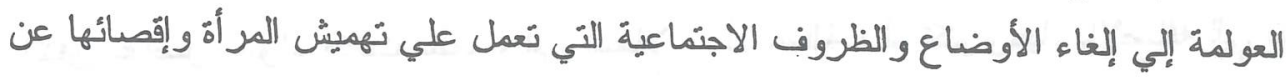

(') http://www.amanjordan.org/a-news/wmprint.php?ArtID=5055

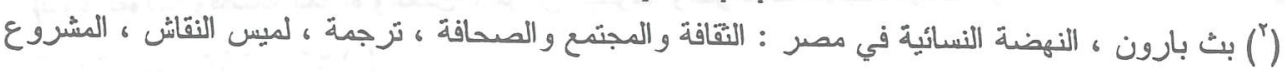

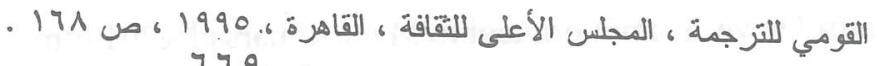
$-779$. 
المشاركة في العباة الثقافية و الافتصادية و السياسيةً ، بحيث بعاد دمجها كقوة فاعلة لدفع حركنة

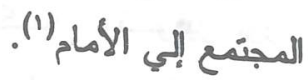

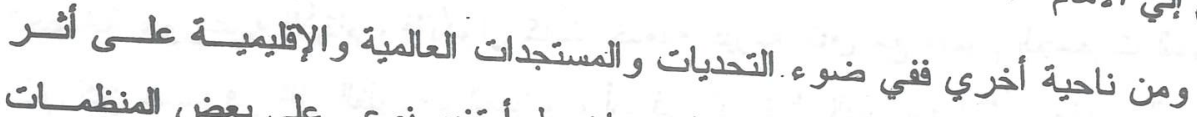

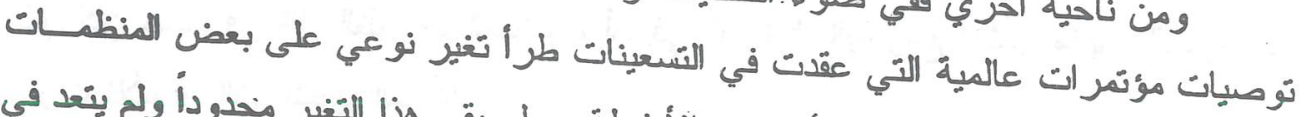

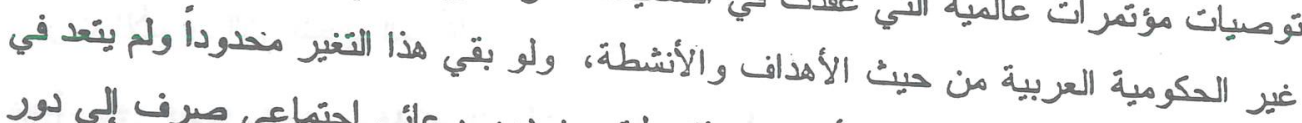

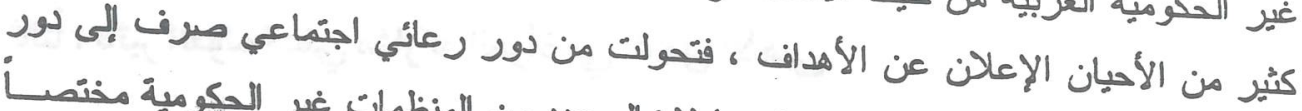

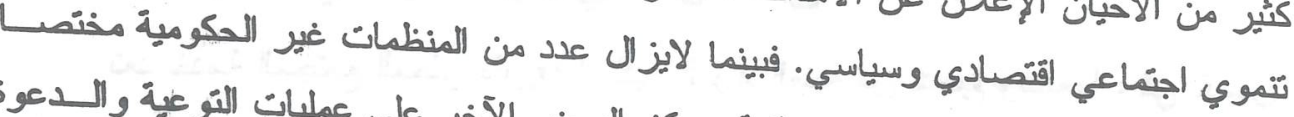

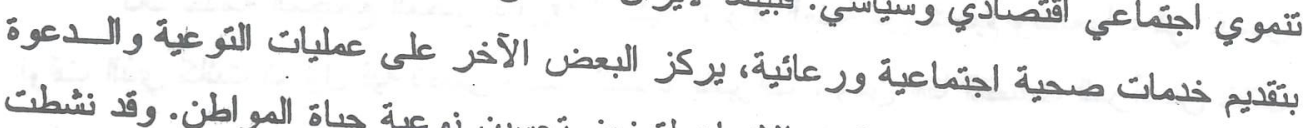

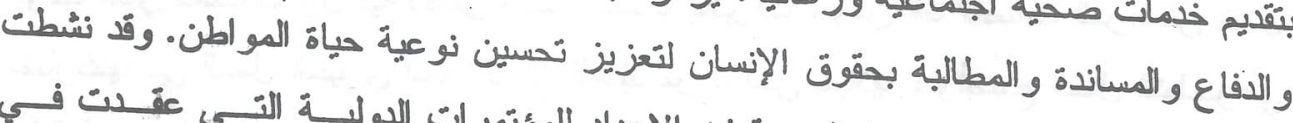

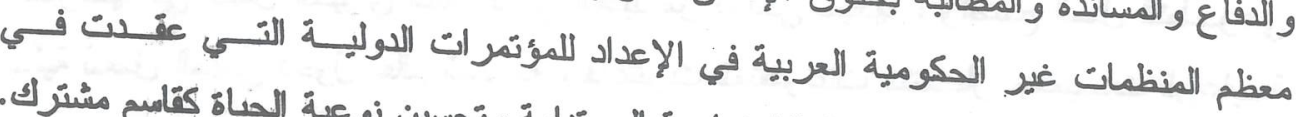

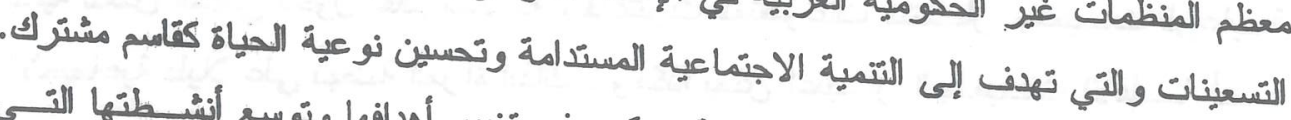

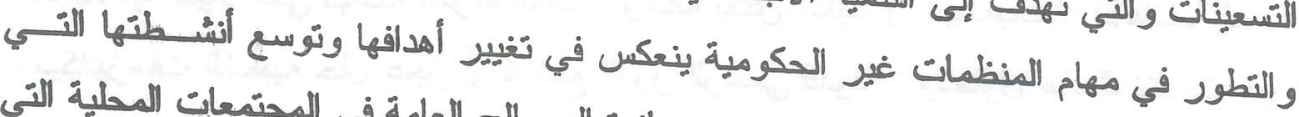

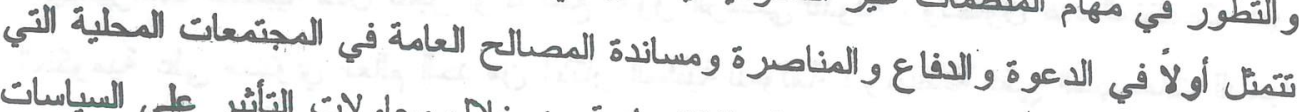

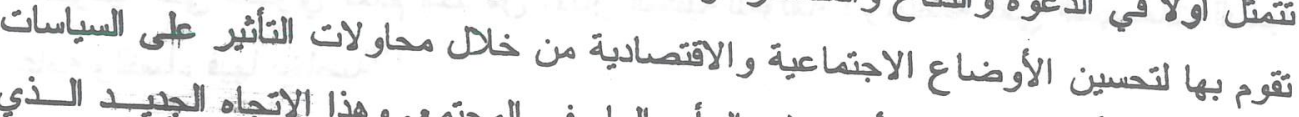

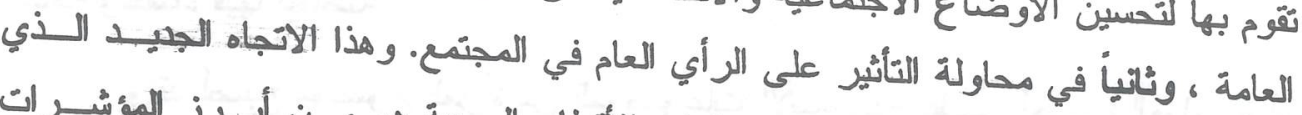

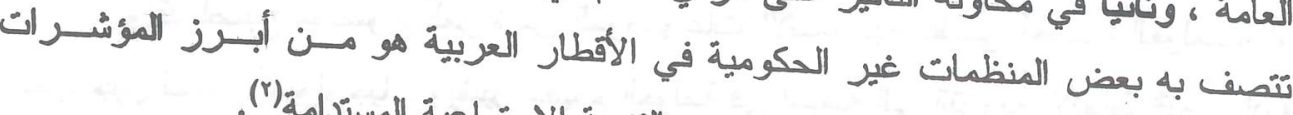

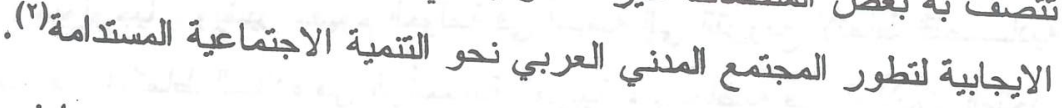

ولكي تتولي العولمة إعادة صياغةة عالمنا وفق نمط معد ، بما في ذلك إعادة تشكيل

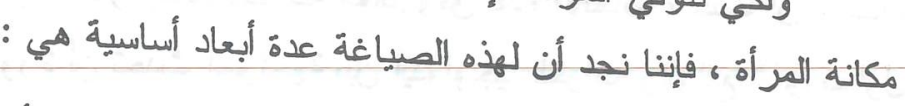

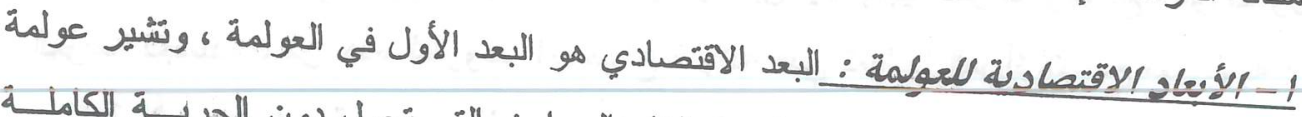

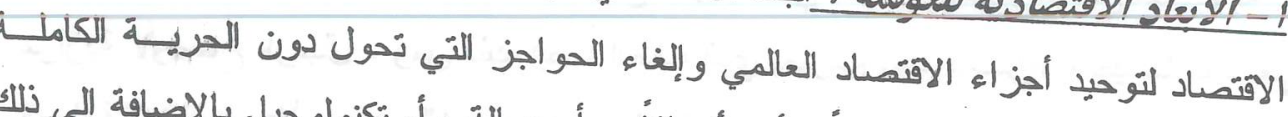

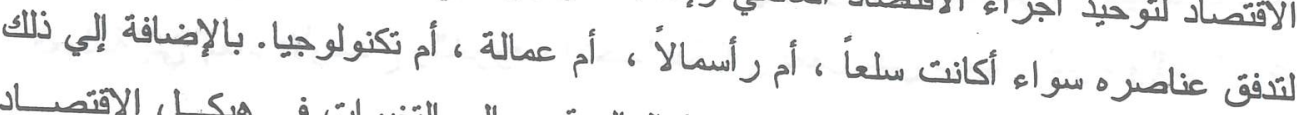

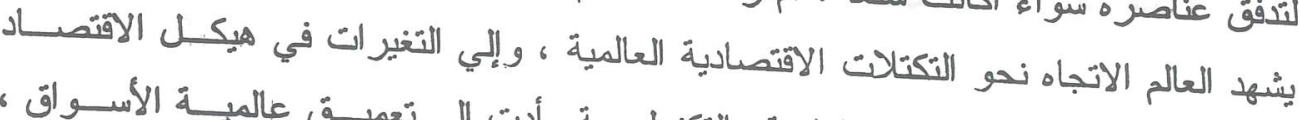

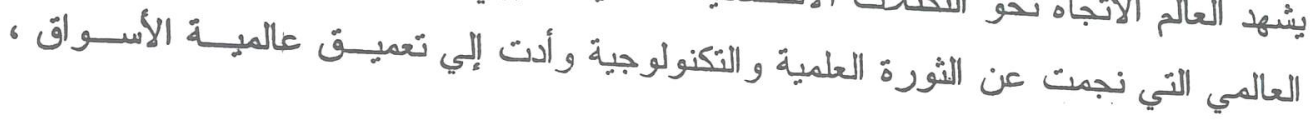

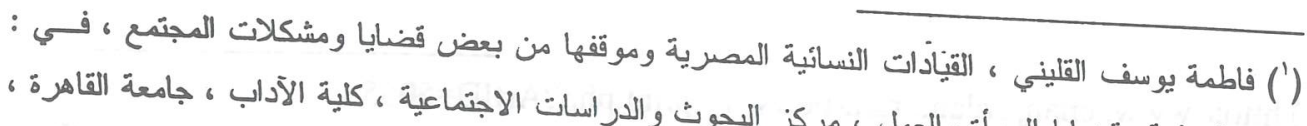

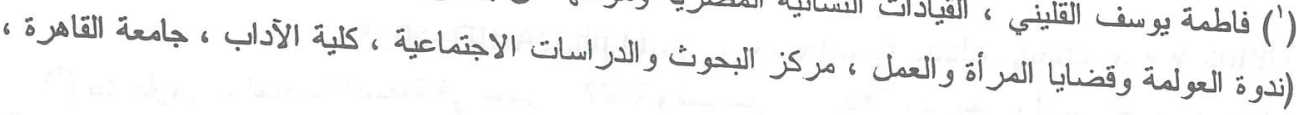

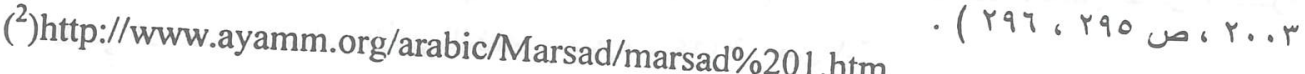




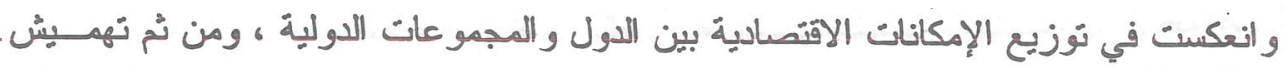

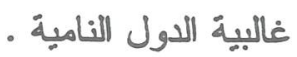

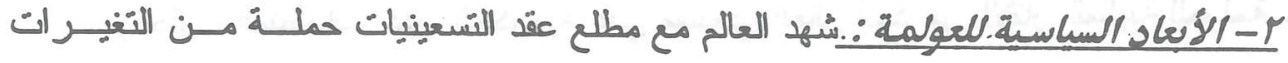

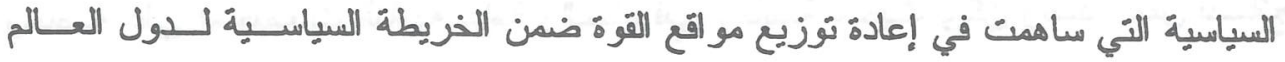

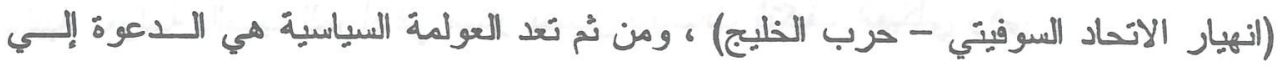
اعتماد الديمقر اطية الليبر اليةة السياسية وحقوق الإنسان والحريات الفردية ، و هي إعلان لنهاية

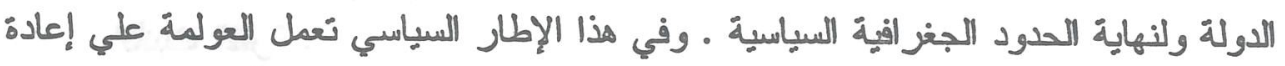

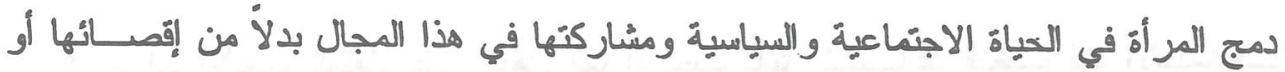

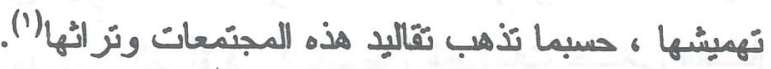
ومن أبعاد العولمة السياسية :

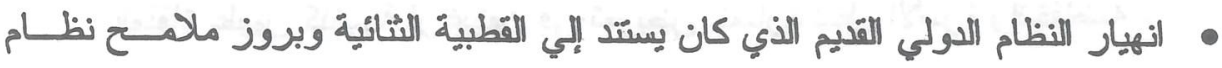
عالمي جديل

• تامي دور المجنمع المني أي المنظمات الدولية غير الحكومية مثل منظمات حقــوق الإنسان وحماية البيئة وغير ها من المنظمات ذات الصيغة العالميةٌ والتي غدت تتّلكل

$$
\text { بصورة مباشرة في قرارات الدول وتشريعانها ـ }
$$

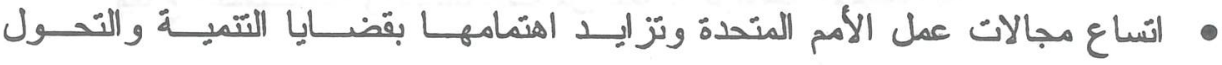

$$
\text { الديمقر اطي (r) }
$$

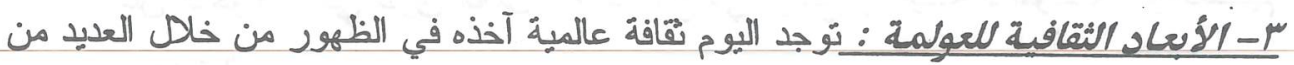
وسائط الإعلام ، حيث تختلط الآر اء و القيم الدولية بالهو ايات الوطنية وتلونها بطابعها ـ فقــــ

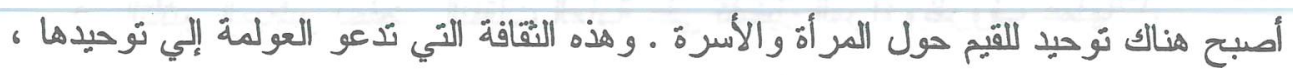

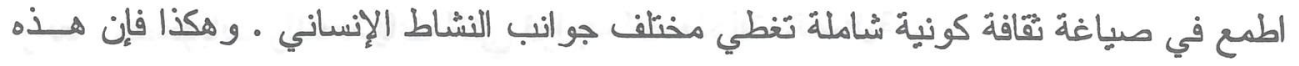

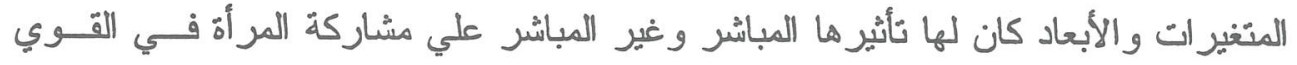
العاملة وخاصة في المجتمع المصري ، وهو الأمر الذي تعمل العولمة علي تجسيده من خله

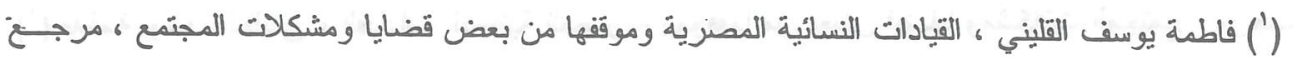

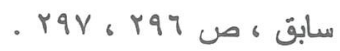

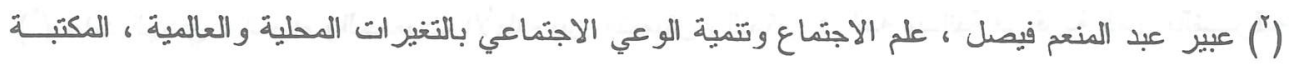

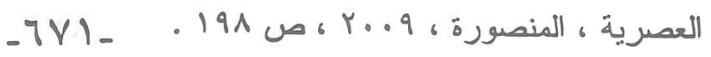




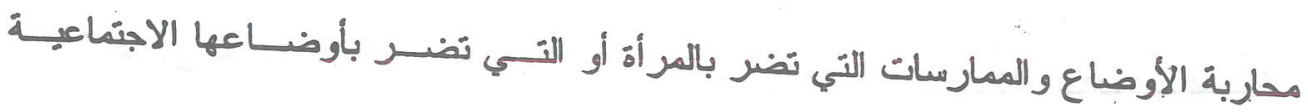

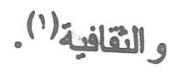

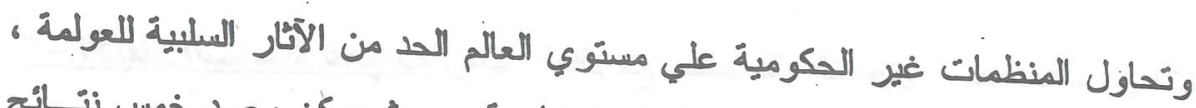

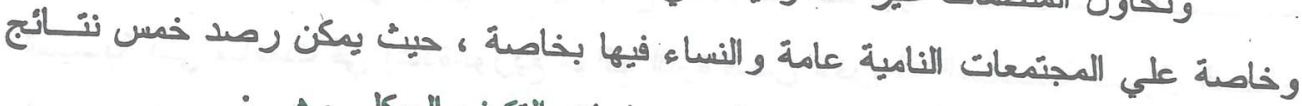

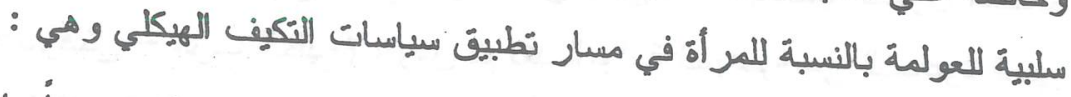

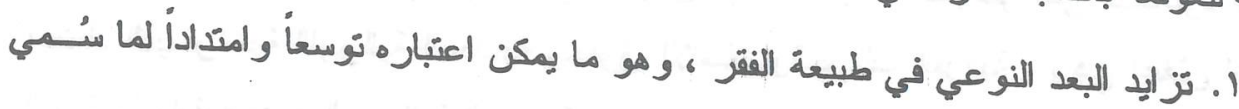
"تأنيث الفقر" •

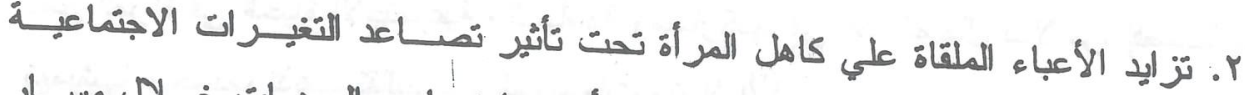

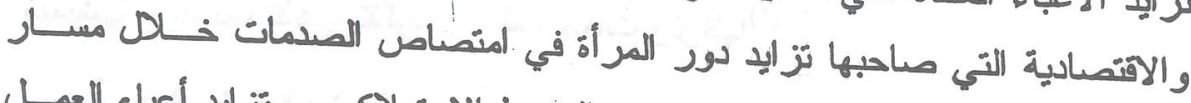

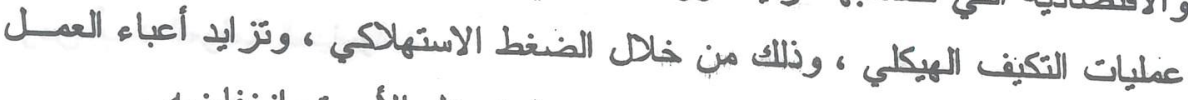

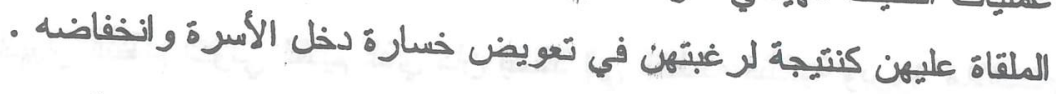

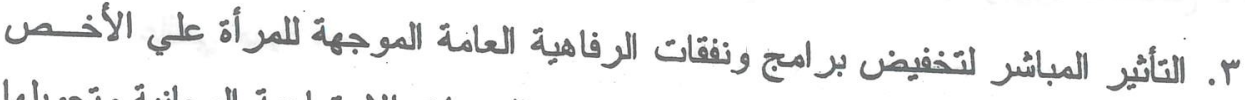

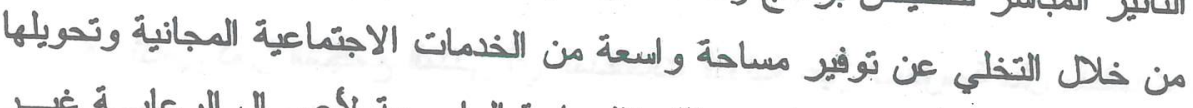

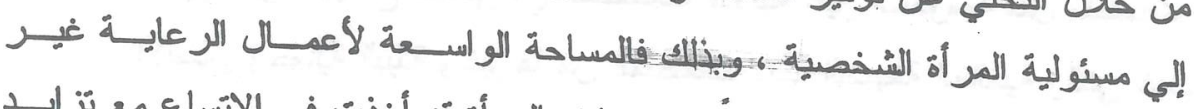

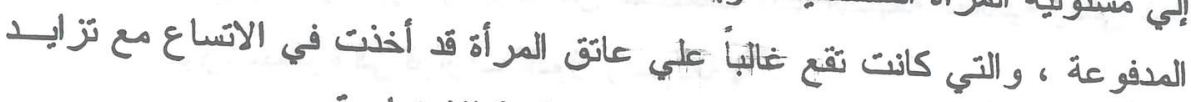
إيقاع الخصخصة والاقنطاعات من نفقات الرفاهية الاجتماعية .

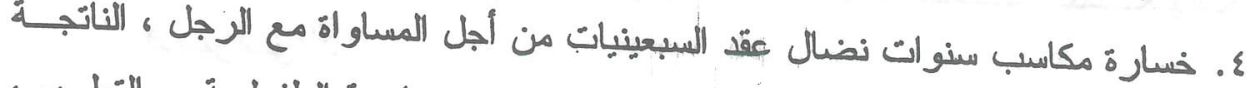

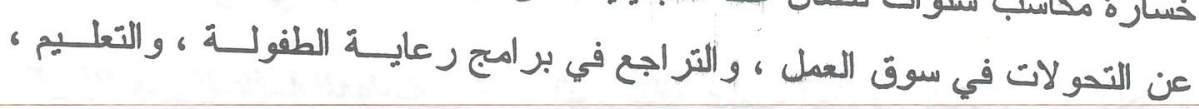

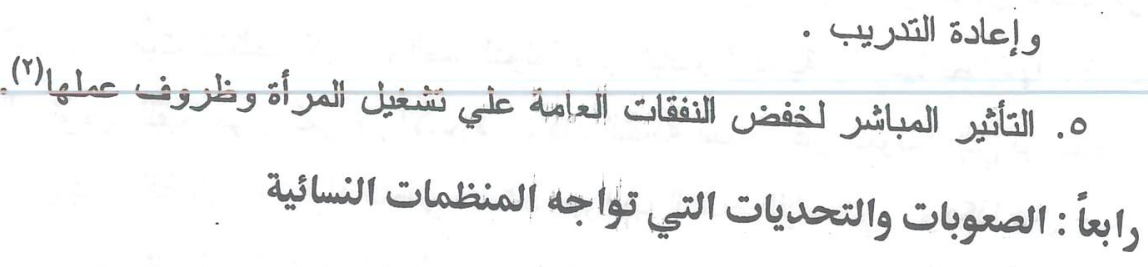

(') فاطمة يوسف القليني ، القيادات النسائية المصرية وموقفها من بعض قضايا ومشكلات المجتمع ، مرجبح

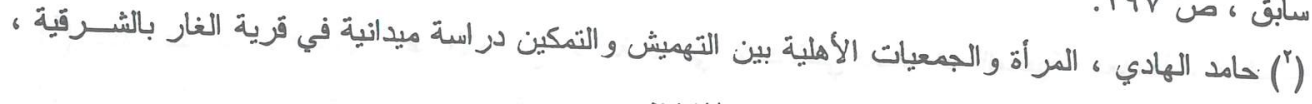

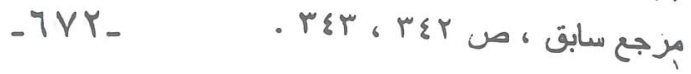


معوقات العمل الأهلي النطوعي في العالم العربي موجودة "بشُكل أو بآخر في غالبية.

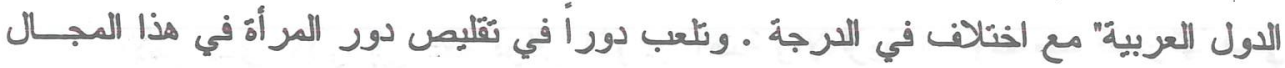
وتتحسد تلاك المعوقات في النقاط الثاليةً :

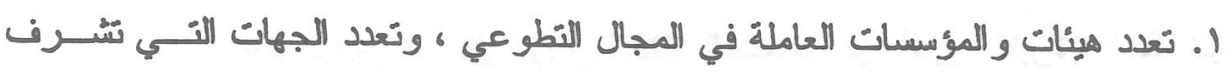

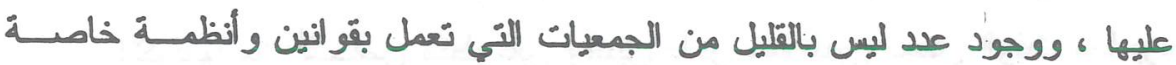
ومسنقّة

r. تُعدية الجهات الرسمية التي تمنح تر اخيص للمنظمات و الجمعيات مما بــؤدي إلــي

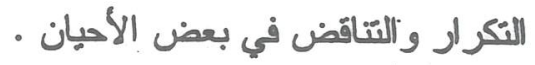

ب. تعدديةٌ الشخصبات ذات النفوذ السياسي التي تتولي رئاسة إدارة الهيئات والمنظمـات

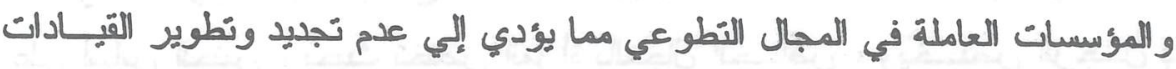

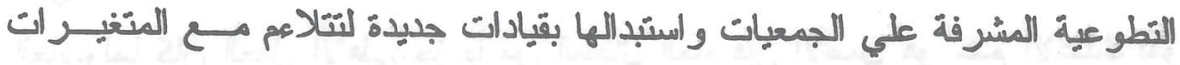

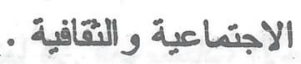

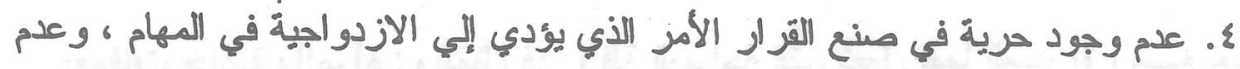

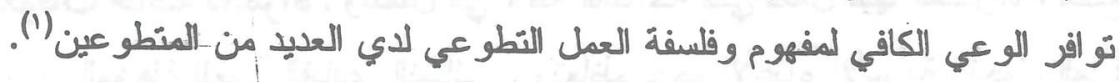

ه. غياب استر اتيجبة نمكين شاملة وغلبة استر اتيجيةً إشباع الاحتياجات الضروريةً .

7. ضعف الوعي بأهمية التمكين ومفهومه المقيقي لدي المنظمات النسـائية وأجهزتهـــا

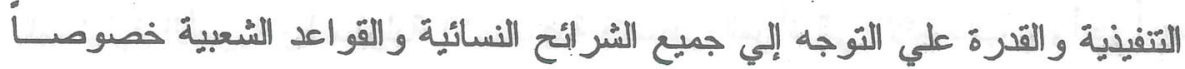

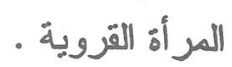

V. الافتقار إلي التفاعل و التو اصل وتبادل الخبرات مع الأطر اف المختلفة ذات الخبــرات

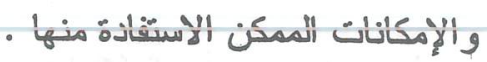

A. مو اجهة القو انين المقبدة لنشاط الجمعيات ، فالتشريغات العربيةً تقبد بدرجات منفاوتــة

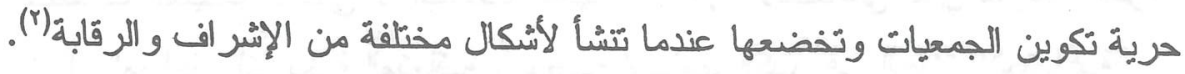

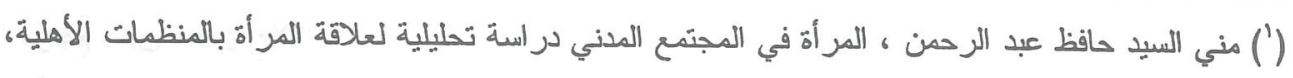

$\left({ }^{2}\right)$ http://www.awapp.org/wmview.php?ArtID=1043\&page=4

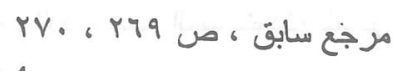




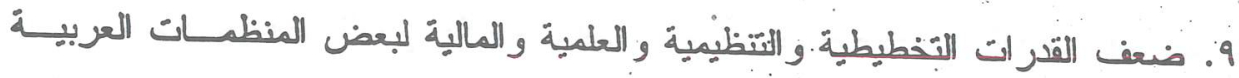

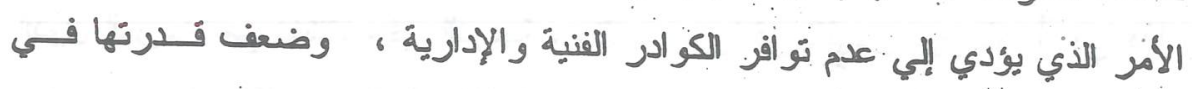

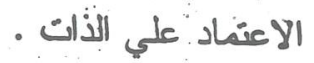

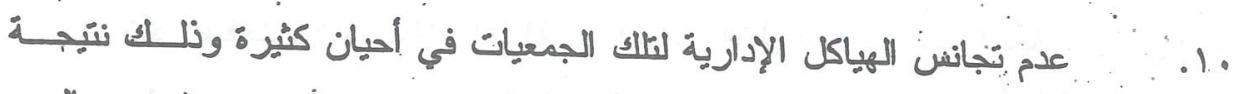

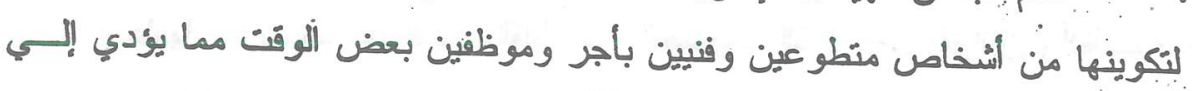

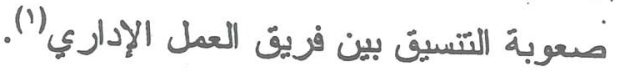
وبالإضافة إلي ذلاك هناك كثير من معوقات مشاركة المرأة في العطل الأهلي النطوعي و أهمها: - معوقات موتبطة بـالمجتمع : ماز الت القيم و العادات الاجتماعيةٌ تقوم علي تقّـِّم الأدوار

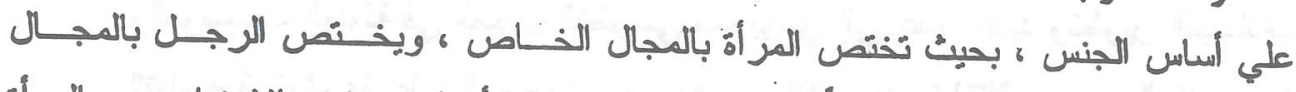

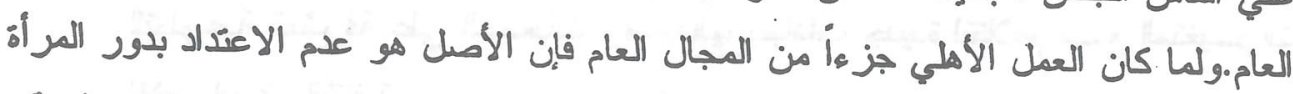
ومشاركتها فيه ، ونظرة المجنمع إلي المرأة تقلل أهميته مشاركتها في المؤسسات الاجنماعيةً.

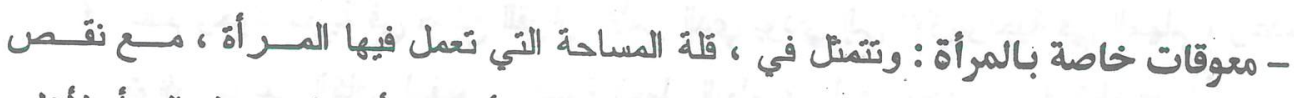

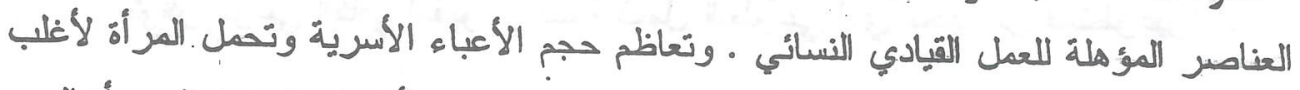

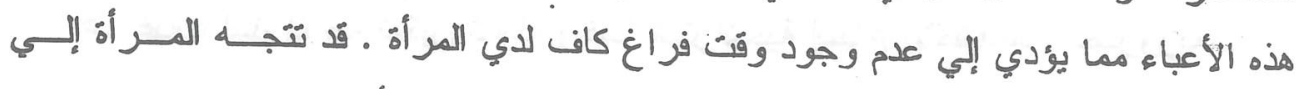

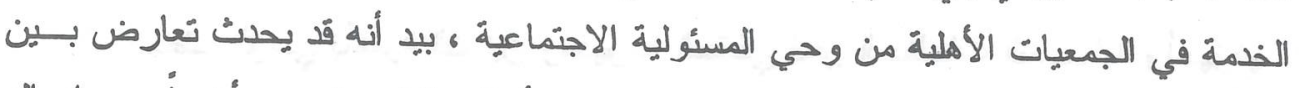

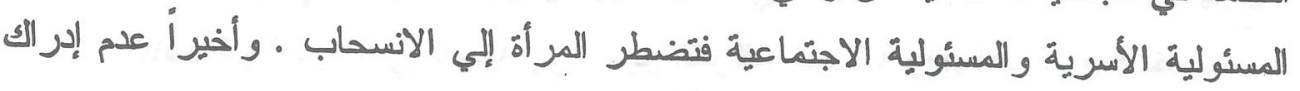

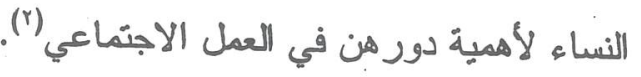

حاتمة

من خلال الإطلامة التاريخية يتضح لنا أن مشاركة المرأة في مصــر فـي أنشـــة منظمات المجتمع المدني لا اختّلف علبها ـ فالدور الاجتماعي الذي مارسته المرأة المصربية خلال المراحل التاريخية المنعاقبة ، يوضح إسهامها الكبير في الحياة الاجنماعيةً .

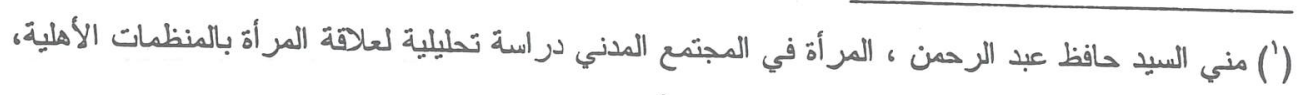

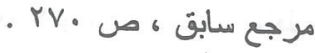

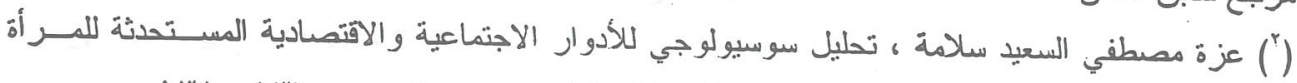

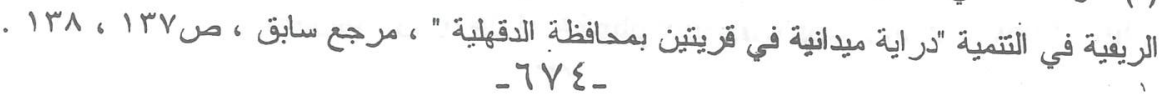




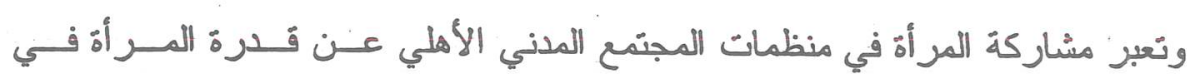
المشاركة في عملية التتميةً بوجه عام ، وتحقيق الأهداف الوطنية و القومية من خلال نو اجدها

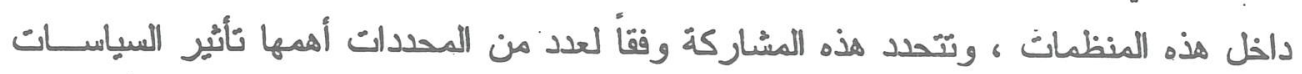

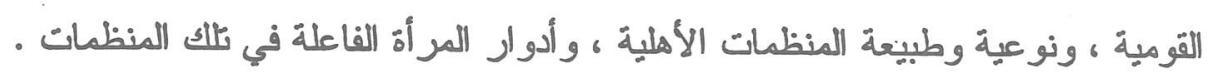
ولقد مثل ظُهور الجمعيات الأهلية الخاصة بالمر أة علامة بارزة في مشاركة المرأة في

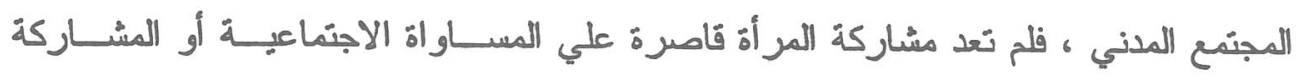

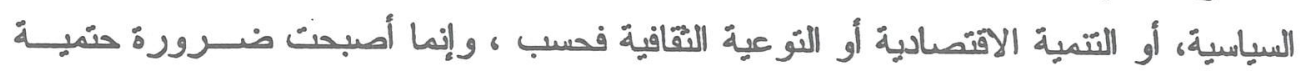

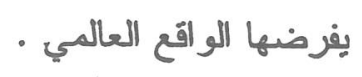

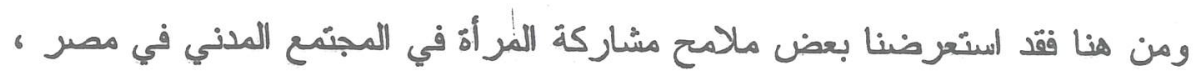

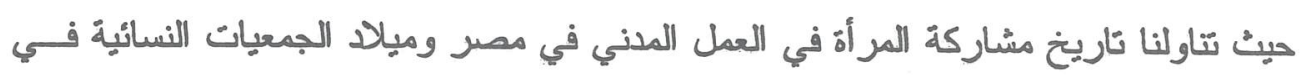

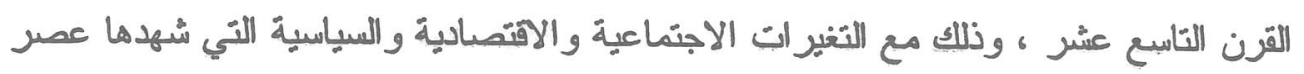

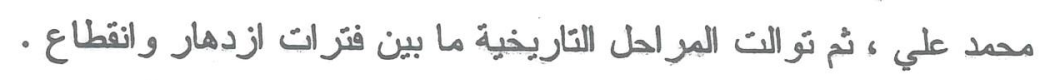

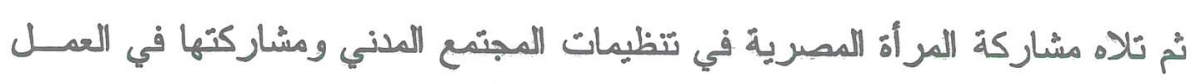

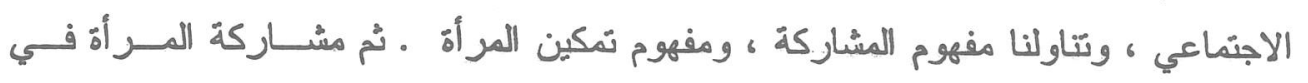

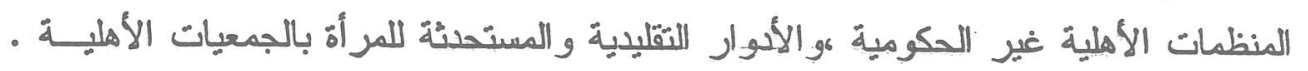

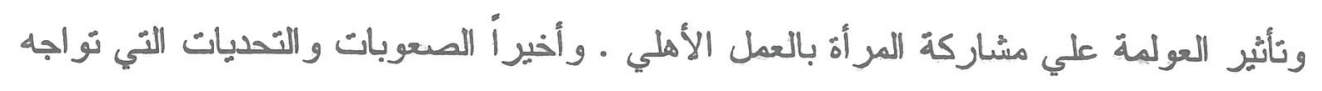
المنظمات النبيائية. 
